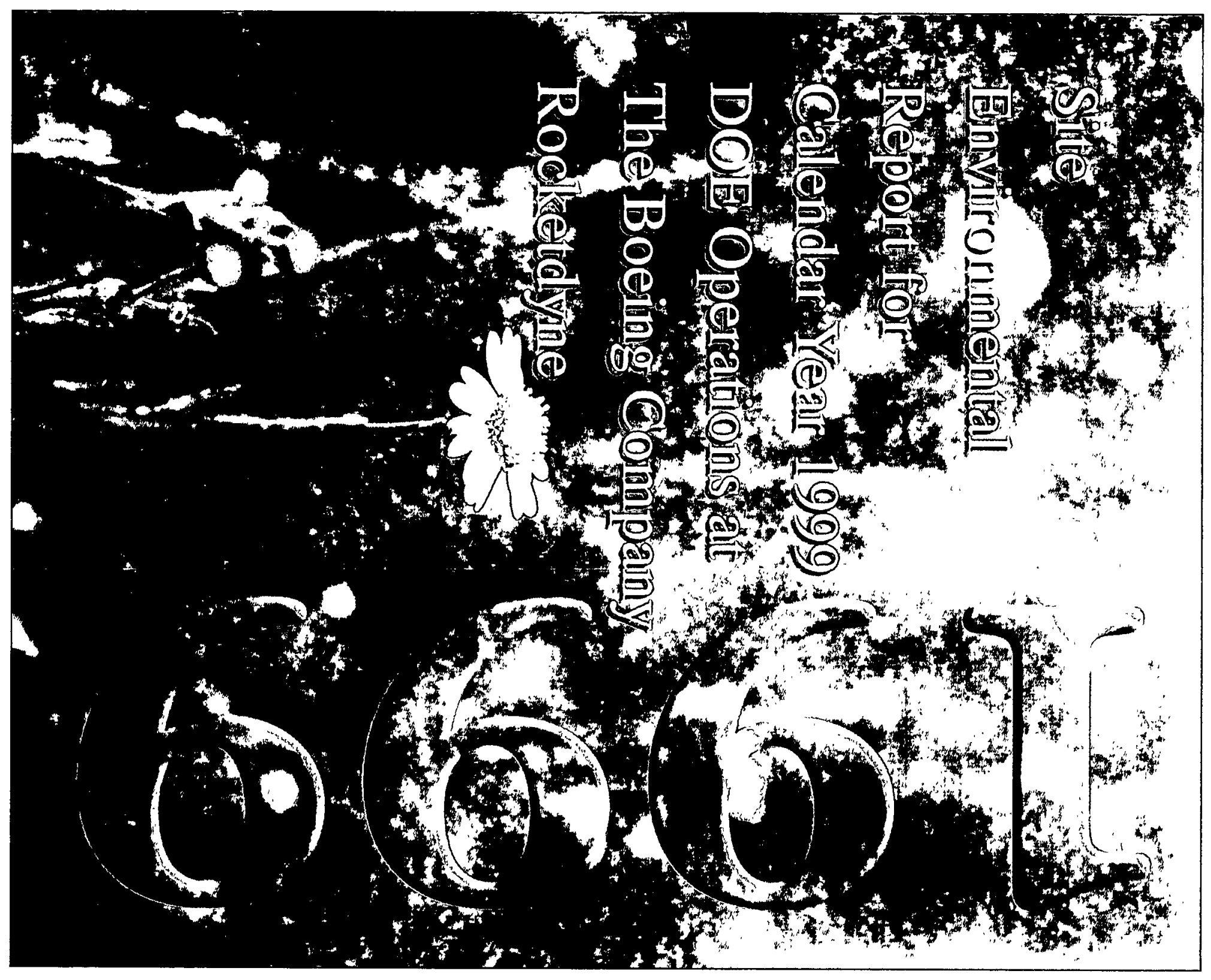




\section{Department of Energy \\ Oakland Operations Office \\ 1301 Clay Street \\ Oakland, Calitornia 94612-5208}

\section{OCT 022000}

Distribution:

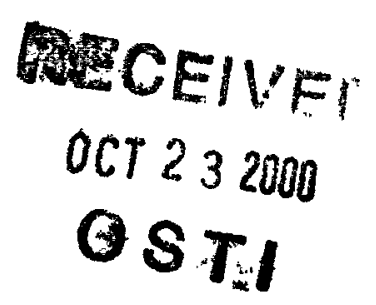

Subject: 1999 Site Environmental Report (SER) for the Energy Technology Engineering Center (ETEC)

The Boeing Company Rocketdyne has prepared this report for the U.S. Department of Energy (DOE). It is a comprehensive summary of the Department's environmental protection activities at ETEC in Canoga Park, California for calendar year 1999. SERs are prepared annually for all DOE sites with significant environmental activities, and distributed to external regulatory agencies, interested organizations and individuals.

To the best of my knowledge, this report accurately summarizes the results of the 1999 environmental monitoring and restoration program at ETEC for DOE. This statement is based on reviews conducted by DOE Oakland Operations Office staff and by the staff of The Boeing Company.

A reader survey form is provided with this report to provide comments. Write directly to the above address. Questions may also be directed to Philip Boehme, U.S. Department of Energy, ETEC Site Office at (818) 586-5571.

Sincerely,

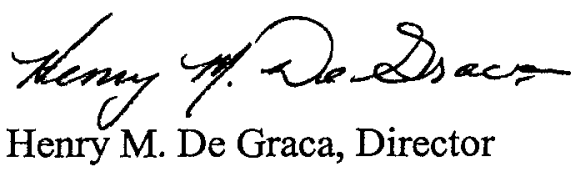

Oakland Environmental Programs Division 


\section{DISCLAIMER}

This report was prepared as an account of work sponsored by an agency of the United States Government. Neither the United States Government nor any agency thereof, nor any of their employees, make any warranty, express or implied, or assumes any legal liability or responsibility for the accuracy, completeness, or usefulness of any information, apparatus, product, or process disclosed, or represents that its use would not infringe privately owned rights. Reference herein to any specific commercial product, process, or service by trade name, trademark, manufacturer, or otherwise does not necessarily constitute or imply its endorsement, recommendation, or favoring by the United States Government or any agency thereof. The views and opinions of authors expressed herein do not necessarily state or reflect those of the United States Government or any agency thereof. 


\section{DISCLAIMER}

\section{Portions of this document may be illegible in electronic image products. Images are produced from the best available original document.}




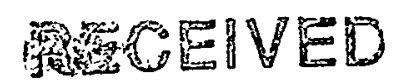

OCT 232819

STI

\title{
Site Environmental Report for Calendar Year 1999 DOE Operations at The Boeing Company \\ Rocketdyne
}

\author{
Prepared by the Staff at \\ The Boeing Company \\ Rocketdyne \\ ACD3-76SF00700
}

September 2000 
RD00-159

This page intentionally left blank. 


\section{Q BonENo}

\section{CERTIFICATE OF ACCURACY}

I certify that I have personally examined and am familiar with the information submitted herein and, based on inquiry of those individuals immediately responsible for preparing this report, I believe that the submitted information is true, accurate, and complete.

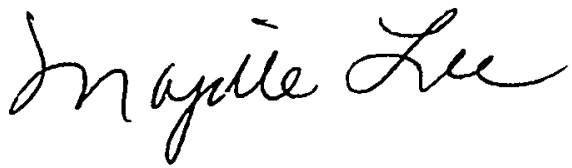

Majelle E. Lee

Program Manager

DOE Site Closure

The Boeing Company Rocketdyne

September 28, 2000 
RD00-159

This page intentionally left blank. 


\section{Department of Energy \\ Oakland Operations Office \\ 1301 Clay Street \\ Oakland, California 94612-5208}

\section{OCT 022000}

Distribution:

Subject: 1999 Site Environmental Report (SER) for the Energy Technology Engineering Center (ETEC)

The Boeing Company Rocketdyne has prepared this report for the U.S. Department of Energy (DOE). It is a comprehensive summary of the Department's environmental protection activities at ETEC in Canoga Park, California for calendar year 1999. SERs are prepared annually for all DOE sites with significant environmental activities, and distributed to external regulatory agencies, interested organizations and individuals.

To the best of my knowledge, this report accurately summarizes the results of the 1999 environmental monitoring and restoration program at ETEC for DOE. This statement is based on reviews conducted by DOE Oakland Operations Office staff and by the staff of The Boeing Company.

A reader survey form is provided with this report to provide comments. Write directly to the above address. Questions may also be directed to Philip Boehme, U.S. Department of Energy, ETEC Site Office at (818) 586-5571.

Sincerely,

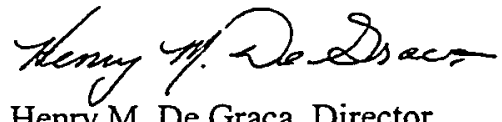

Henry M. De Graca, Director

Oakland Environmental Programs Division 
RD00-159

This page intentionally left blank 


\section{ACKNOWLEDGMENT}

Preparation of this report has been a collaborative effort of many members of Rocketdyne's Safety, Health and Environmental Affairs (SHEA) department.

- Principal technical contributors are:

- $\quad$ Radiological Topics:

Ning Liu
Ray McGinnis
Richard Harcombe
Phil Rutherford
Paul Chang
Bettina Leeney
Ravnesh Amar
Brian Sujata
Art Lenox
Dave Dassler
Leul Tewelde
Beverly Hurt
Blythe Latimer

- Groundwater:

- $\quad$ Surface Water:

- Waste Management:

Ravnesh Amar

- RCRA Facility Investigation:

- Air:

- Editing and review have been performed by Phil Rutherford, Sandy Samuels, and Majelle Lee.

- Administrative assistance was provided by Pat Ohara.

- Publication assistance was provided by the Rocketdyne Graphics \& Publications staff. 
RD00-159

This page intentionally left blank.

viii

0300199.doc 


\section{CONTENTS}

1. EXECUTIVE SUMMARY .......................................................................................... 1-1

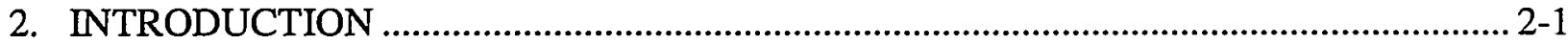

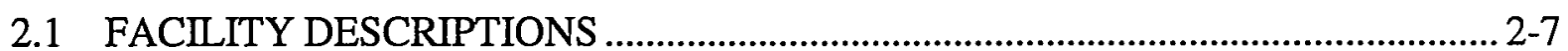

2.1.1 Radiological Facilities ............................................................................ 2-7

2.1.2 Former Sodium Facilities....................................................................... 2-8

3. COMPLIANCE SUMMARY ………...................................................................... 3-1

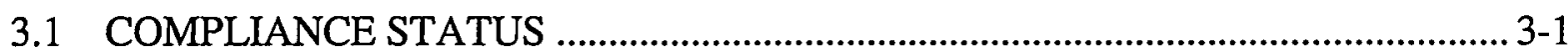

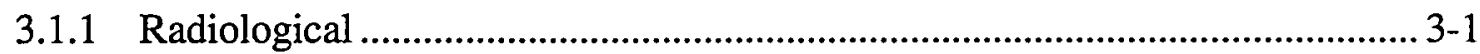

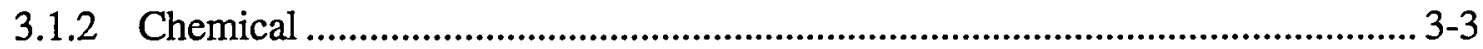

3.1.3 Public Participation.................................................................................. 3-7

3.1.4 Permits and Licenses (Area IV) ................................................................. 3-9

3.2 CURRENT ISSUES AND ACTIONS............................................................... 3-10

3.2.1 Progress in Radiological Decommissioning Operations................................ 3-10

3.2.2 Agency for Toxic Substances and Disease Registry........................................ 3-11

4. ENVIRONMENTAL PROGRAM INFORMATION ......................................................... 4-1

4.1 ROCKETDYNE ENVIRONMENTAL PROTECTION AND REMEDIATION ....... 4-1

4.2 ENVIRONMENTAL MONITORING PROGRAM .............................................. 4-3

4.2.1 Radiological Monitoring ........................................................................ 4-4

4.2.2 Non-Radiological Monitoring....................................................................... 4-9

4.3 ENVIRONMENTAL TRAINING......................................................................... 4-9

4.4 WASTE MINIMIZATION AND POLLUTION PREVENTION............................... 4-10

4.4.1 Program Planning and Development .............................................................. 4-10

4.4.2 Training and Awareness Programs ............................................................. 4-11

4.4.3 Waste Minimization and Pollution Prevention Activities ............................... 4-11

4.4.4 Tracking and Reporting System...................................................................... 4-12

5. ENVIRONMENTAL RADIOLOGICAL MONITORING ............................................... 5-1

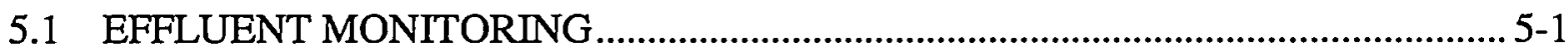

5.2 ENVIRONMENTAL SAMPLING ….......................................................................... 5-7

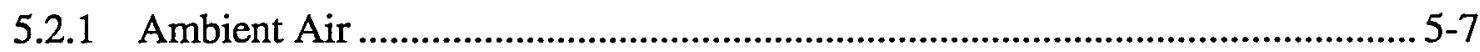

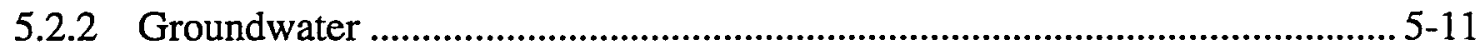

5.2.3 Surface Water and Domestic Water Supply ............................................... 5-13

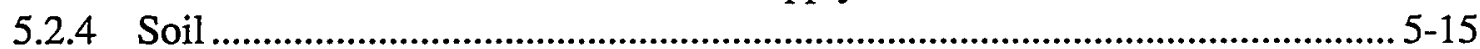

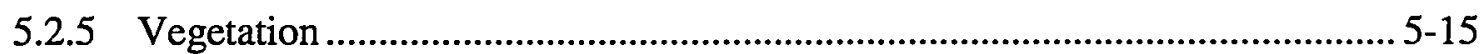

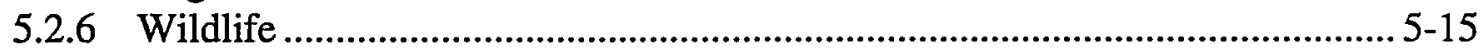

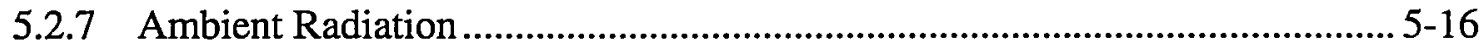

5.3 ESTIMATION OF RADIATION DOSE ....................................................... 5-18

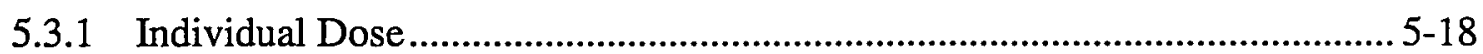

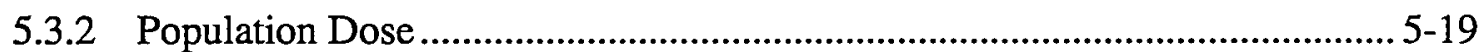

6. ENVIRONMENTAL NON-RADIOLOGICAL MONITORING ........................................ 6-1

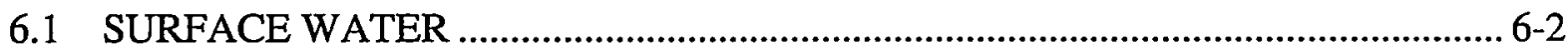

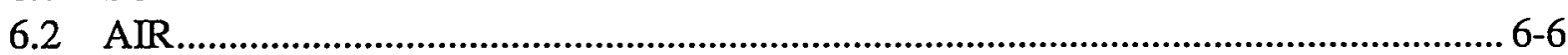

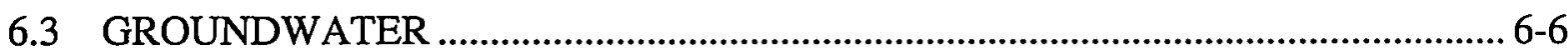


RD00-159

\section{CONTENTS}

7. ENVIRONMENTAL MONITORING PROGRAM QUALITY CONTROL ....................... 7-1

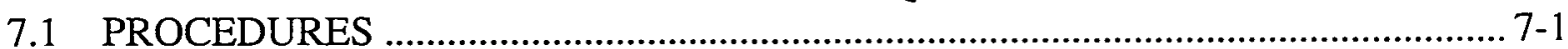

7.2 RECORDS

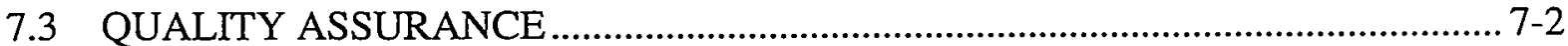

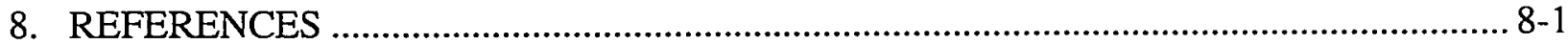

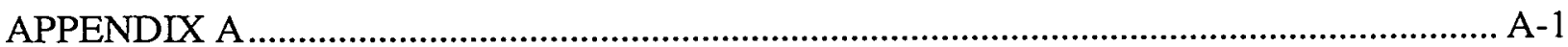

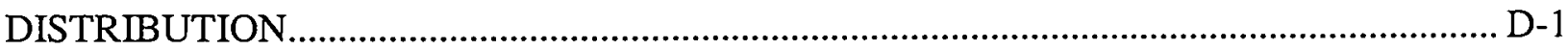

\section{FIGURES}

2-1. Santa Susana Field Laboratory Site Arrangement........................................................... 2-2

2-2. Map Showing Location of SSFL ................................................................................... 2-3

2-3. The Boeing Company, Rocketdyne-Santa Susana Field Laboratory Site, Area IV ............................................................................................ 2-5

2-4. Map of Santa Susana Field Laboratory Area IV, Radiological Facilities ......................... 2-6

4-1a. Soil/Sediment Environmental Sampling Locations........................................................... 4-6

4-1b. Radiological Sampling and Monitoring Locations.......................................................... 4-7

5-1. Map of Santa Susana Field Laboratory Area IV Sampling Stations ................................. 5-8

5-2. Tritium Concentration in Water from Well RD-34A.................................................. 5-13

5-3. Census Tract Boundaries (1990) within 10 miles of SSFL (individual tracts are identified by number) ..................................................................... 5-20

5-4. SSFL Site-Centered Demography to $8 \mathrm{~km}$ (1990), Showing Number of Persons Living in Each Grid (daytime employment for SSFL)

5-5. SSFL Site-Centered Demography to $16 \mathrm{~km}$ (1990), Showing Number of Persons Living in Each Grid

5-6. SSFL Site-Centered Demography to $80 \mathrm{~km}$ (1990), Showing Number of Persons Living in Each Grid (heavily populated areas are shown by shading) .......... 5-23

6-1. Locations of Surface Water Runoff Collectors Along Northwest Boundary of SSFL, Area IV ..................................................................................................... 6-4

6-2. Location of Wells Used in Groundwater Management Program ...................................... 6-5

6-3. TCE Occurrences in Groundwater at SSFL, Area IV (exceeding $5 \mathrm{ppb}$ ) ......................... 6-8

7-1. Quality Assessment Program Results for QAP-50 and QAP-51..................................... 7-3 


\section{TABLES}

3-1. 1999 Agency Inspections/Visits Related to Environmental Remediation .......................... 3-2

3-2. SSFL Current Underground Storage Tanks ............................................................... 3-9

4-1. Organizations Conducting Radiological Environmental Sampling …............................... 4-8

5-1. Atmospheric Effluents to Uncontrolled Areas ................................................................. 5-2

5-2. Filtered Exhaust and Ambient Air Radioactivity Concentrations - 1999 ......................... 5-6

5-3. Radiation Exposure Dose due to Atmospheric Effluents - 1999 …................................... 5-7

5-4. Sampling Location Description ....................................................................................... 5-9

5-5. Ambient Air Radioactivity Data-1999.......................................................................... 5-11

5-6 Radioactivity in Groundwater at SSFL-1999 .......................................................... 5-12

5-7. NPDES Discharge Radioactivity Data for Northwest Slope Monitoring - 1999 ........... 5-14

5-8. Domestic Water Supplies Radioactivity Data .................................................................. 5-14

5-9. Environmental Soil Radioactivity Data-1999.........................................................5-16

5-10. 1999 SSFL Ambient Radiation Dosimetry Data ........................................................... 5-18

5-11. Public Exposure to Radiation and Radioactivity from DOE Operations at SSFL-1999. 
RD00-159

This page intentionally left blank. 


\section{EXECUTIVE SUMMARY}

This Annual Site Environmental Report (ASER) for 1999 describes the environmental conditions related to work performed for the Department of Energy (DOE) at Area IV of the Rocketdyne Santa Susana Field Laboratory (SSFL). In the past, these operations included development, fabrication, and disassembly of nuclear reactors, reactor fuel, and other radioactive materials under the former Atomics International Division. Other activities included the operation of large-scale liquid metal facilities for testing of liquid metal fast breeder components at the Energy Technology Engineering Center (ETEC), a government-owned, company-operated test facility within Area IV. All nuclear work was terminated in 1988, and subsequently, all radiological work has been directed toward decontamination and decommissioning (D\&D) of the previously used nuclear facilities and associated site areas. Large-scale D\&D activities of the sodium test facilities began in 1996.

Results of the radiological monitoring program for the calendar year 1999 continue to indicate that there are no significant releases of radioactive material from Rocketdyne sites. All potential exposure pathways are sampled and/or monitored, including air, soil, surface water, groundwater, and direct radiation. All radioactive wastes are processed for disposal at DOE disposal sites and other sites approved by DOE and licensed for radioactive waste. Liquid radioactive wastes are not released into the environment and do not constitute an exposure pathway.

Calculated radiation doses to the public due to airborne releases and direct radiation are a factor of thousands to millions of times lower than the applicable limits as well as the naturally existing background levels. These theoretically calculated doses are too small to permit direct measurement. Conservative calculations provide upper-limit estimates of possible doses to the public. The radiation dose to a member of the public (maximally exposed individual) due to direct radiation from SSFL is indistinguishable from background. The maximum public dose due to airborne radioactivity released from SSFL facilities is estimated to be $2.2 \times 10^{-7} \mathrm{mrem}$. These doses are far below the annual dose from natural indoor airborne activity of about $200 \mathrm{mrem}$, and the total annual dose from all natural sources of about $300 \mathrm{mrem}$.

During 1999, 26 groundwater wells in Area IV were sampled and analyzed for radiological contaminants. Only naturally occurring radioactivity has been found in groundwater, except for low concentrations of tritium found in four wells, which are well below the Federal and State drinking water standards,

Currently, 45 on-site wells in Area IV of SSFL characterize the hydrogeology and water quality of known groundwater chemical contamination. These wells were analyzed for chemical and radiological constituents, as appropriate. Three interim groundwater remediation systems operated in Area IV during 1999; they were located at the Former Sodium Disposal Facility (FSDF), the Radioactive Material Handling Facility (RMHF), and Building 4059. Although trichloroethylene (TCE) was detected in these areas, no exposure to the public has occurred because no exposure pathways exist. These contaminated areas are being remediated. The interim treatment unit operated at Building 4059 also pumped water to keep the water table below the test vault in the building. The three existing areas of TCE contamination in the groundwater in the northwest part of Area IV were monitored in 1999. 
During 1999, 18 Area IV regulatory agency inspections, audits, and visits were conducted. These inspections were carried out by the California Department of Toxic Substances Control (DTSC), the California Department of Health Services/Radiological Health Branch (DHS/RHB), the US Department of Energy (DOE), the Ventura County Air Pollution Control District (VCAPCD), the Ventura County Environmental Health Department (VCEHD), and the California Occupational Safety and Health Administration (Cal/OSHA). There were no Notices of Violations (NOV) as a result of these inspections and audits.

In summary, this Annual Site Environmental Report provides information showing that there are no indications of any potential impact on public health and safety due to the operations conducted at the SSFL. All measures and calculations of off-site conditions demonstrate compliance with applicable regulations, which provide for protection of human health and the environment.

This Annual Site Environmental Report was developed as required by DOE Order 5400.1 and 231.1. In addition, this report summarizes information on environmental and effluent monitoring of DOE-sponsored activities to the regulatory agencies responsible for oversight. Information presented here focuses on Area IV at SSFL where DOE operations were performed. In addition, this report attempts to communicate to our workers, neighbors, and customers, factual information regarding the condition of our environment. To assist us in this effort, a reader response survey form has been included in the back of this report. We would appreciate your comments. 


\section{INTRODUCTION}

This annual report describes the environmental monitoring program implemented by The Boeing Company Rocketdyne at its Santa Susana Field Laboratory (SSFL) facility located in Ventura County, California for calendar year 1999. Part of the SSFL facility, known as Area IV, had been used for the Department of Energy's (DOE) Energy Technology Engineering Center (ETEC) since the 1950s. A broad range of energy-related research and development (R\&D) projects, including nuclear technologies, were conducted at the site. All the nuclear R\&D operations in Area IV ceased in 1988, and the subsequent efforts have been directed toward decontamination and decommissioning (D\&D) of the former nuclear facilities and closure of facilities used for liquid metal research.

\section{Santa Susana Field Laboratory}

The SSFL has been used for various research, development, and test projects funded by several U.S. government agencies, including DOE, Department of Defense (DOD), and National Aeronautics and Space Administration (NASA). The site consists of four administrative areas and undeveloped land. Figure 2-1 shows the arrangement of the site. Area IV is about 290 acres, of which, approximately 90 acres are under DOE's jurisdiction.

In Area IV, starting in 1956, small test and demonstration reactors and critical assemblies were built and operated, reactor fuel elements were fabricated, and used fuel elements were disassembled and decladded. These projects were completed and terminated in the course of the next 30 years. Most of the work is described in detail in the Rocketdyne document "Nuclear Operations at Rockwell's Santa Susana Field Laboratory - A Factual Perspective" [Oldenkamp, 1991]. The only work related to the nuclear operations since 1988 (and during 1999) was the ongoing cleanup and decontamination of the remaining inactive radiological facilities and the off-site disposal of radioactive waste.

The location of the SSFL site in relation to nearby communities is shown in Figure 2-2. Undeveloped land surrounds most of the SSFL site. No significant agricultural land use exists within $30 \mathrm{~km}$ (19 miles) of the SSFL site. While the land immediately surrounding Area IV is undeveloped, suburban residential areas are at greater distances. For example, $2.7 \mathrm{~km}$ (1.7 miles) northwest of Area IV is the closest residential portion of Simi Valley. The community of Santa Susana Knolls lies $4.8 \mathrm{~km}$ ( 3.0 miles) to the northeast. The Bell Canyon area begins approximately $2.3 \mathrm{~km}$ (1.4 miles) to the southeast, and the Brandeis-Bardin Institute is adjacent to the north. 
RD00-159

\begin{tabular}{|c|l|c|c|}
\hline \multicolumn{4}{|c|}{ Subdivisions } \\
\hline Owner & \multicolumn{1}{|c|}{ Jurisdiction } & Acres & Subtotals \\
\hline Rocketdyne & Rocketdyne-Area IV & 289.9 & \\
& Rocketdyne & 784.8 & \\
& Rocketdyne (Undeveloped & $1,324.6$ & $2,399.3$ \\
& land) & 409.5 & \\
\hline Government & NASA (former AFP 57) & 41.7 & 451.2 \\
& NASA (former AFP 64) & & $2,850.5$ \\
\hline Total Acres & & & \\
\hline
\end{tabular}

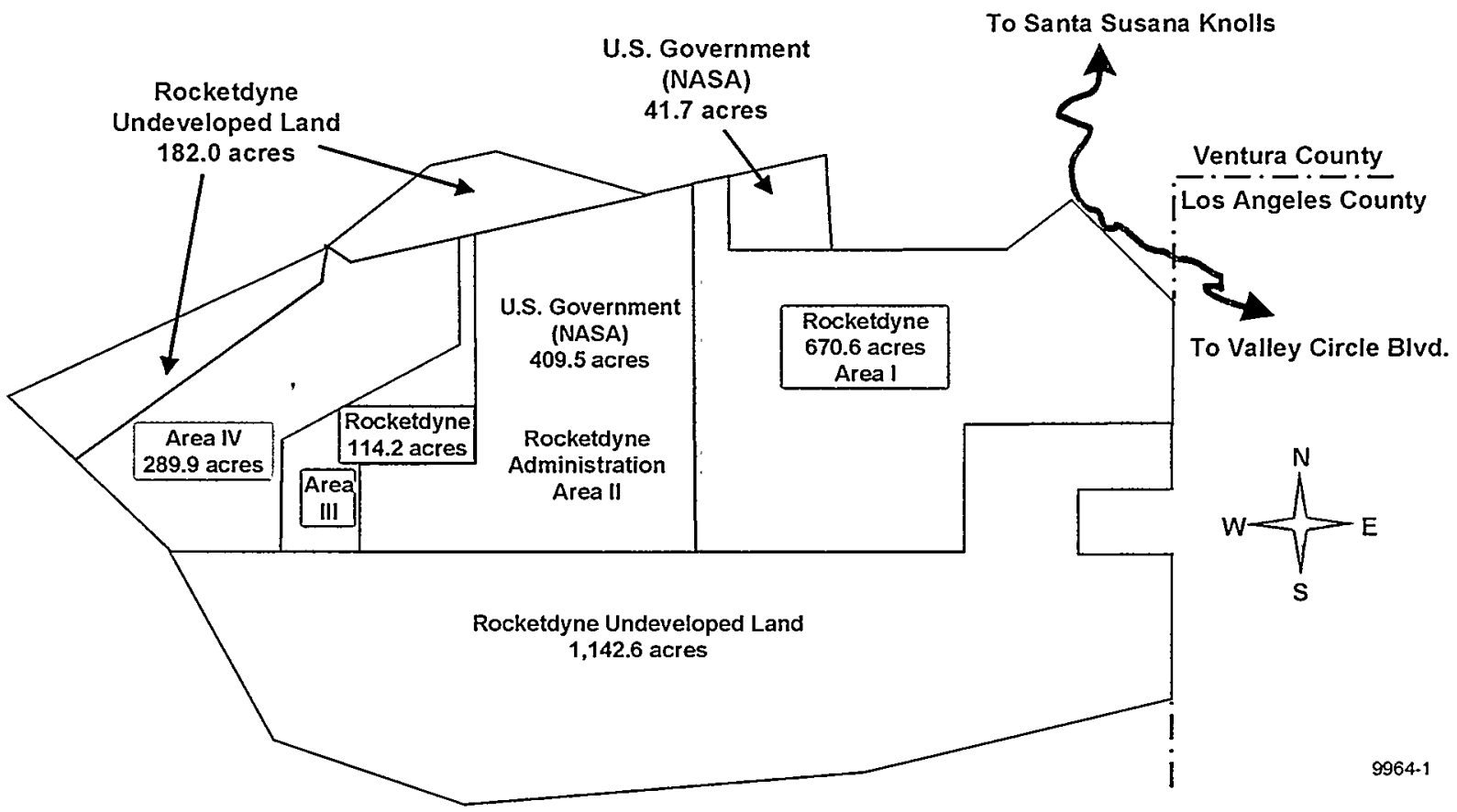

Figure 2-1. Santa Susana Field Laboratory Site Arrangement 


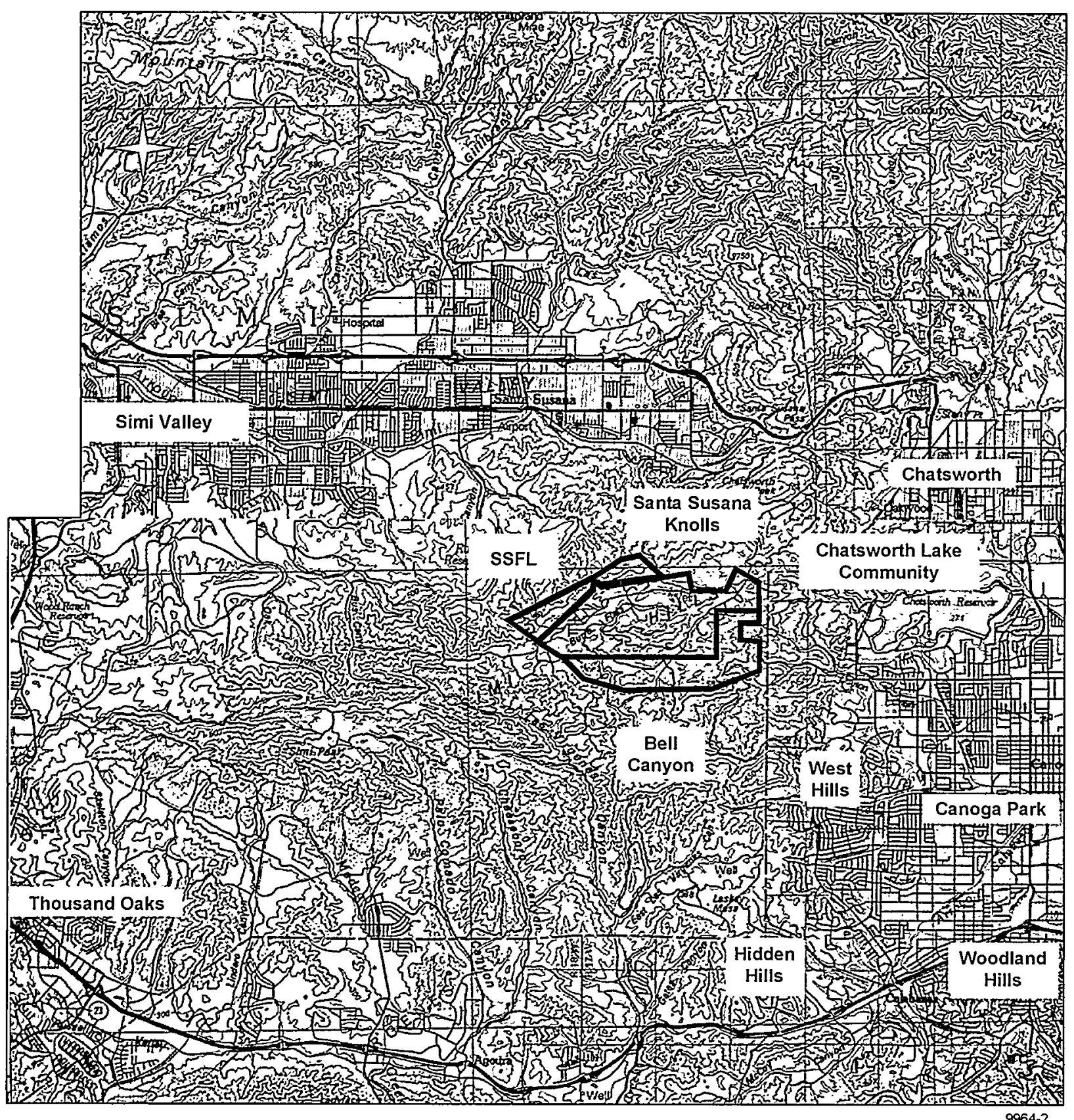

Figure 2-2. Map Showing Location of SSFL 
The Los Angeles basin is a semiarid region whose climate is controlled primarily by the semipermanent Pacific high-pressure cell that extends from Hawaii to the Southern California coast. The seasonal changes in the position of this cell greatly influence the weather conditions in this area. During the summer months, the high-pressure cell is displaced to the north. This results in mostly clear skies with little precipitation. During the winter, the cell moves sufficiently southward to allow some Pacific lows with their associated frontal systems to move into the area. This produces light to moderate precipitation with northerly and northwesterly winds.

During the summer, a shallow inversion layer generally exists in the Los Angeles area. The base and top of this inversion layer usually lie below the elevation of the SSFL site. Thus, any atmospheric release from the SSFL site during the summer would likely result in considerable atmospheric dispersion above the inversion layer prior to any diffusion through the inversion layer into the Simi or San Fernando Valleys. In the winter season, surface airflow is dominated by frontal activity moving easterly through the area. Storms passing through the area during the winter are generally accompanied by rainfall. Airborne mixing varies depending on the location of the weather front relative to the site. Generally, a light to moderate southwesterly wind precedes these storms, introducing a strong onshore flow of marine air and producing slightly unstable air. Wind speeds increase as the frontal systems approach, enhancing mixing and dispersion. Locally, average wind speeds range from 0 to $4.4 \mathrm{~m} / \mathrm{s}(0$ to $9.8 \mathrm{mph})$, mostly from the north and northwest.

Except for the Pacific Ocean, which is approximately $20 \mathrm{~km}$ (12 miles) south, no recreational body of water of noteworthy size is located in the surrounding area. Four major reservoirs providing domestic water to the greater Los Angeles area are located within $50 \mathrm{~km}$ (30 miles) of SSFL. However, the closest reservoir to SSFL (Bard Reservoir, near the west end of Simi Valley) is more than $10 \mathrm{~km}$ (6 miles) from Area IV.

The SSFL site occupies 2,850 acres located in the Simi Hills of Ventura County, California, approximately $48 \mathrm{~km}$ (30 miles) northwest of downtown Los Angeles. The SSFL is situated on rugged terrain with elevations at the site varying from 500 to $700 \mathrm{~m}(1,650$ to 2,250 $\mathrm{ft}$ ) above sea level (ASL). Rocketdyne and DOE-owned facilities (Figures 2-3 and 2-4) share the Area IV portion of this site.

Within Area IV of the SSFL site is a 90-acre area where DOE contract activities are conducted. Rocketdyne now performs all the environmental remediation and restoration activities for the DOE. In 1998, DOE awarded Rocketdyne a contract for the closure of all DOE facilities in Area IV by 2006.

\section{De Soto Facility}

Two nuclear research laboratories were located in Building DS104 at the company's De Soto facility. The research work was terminated in 1995, and the facility was decontaminated and decommissioned in 1997. After extensive survey and verification in 1998, the State of California Department of Health Services (DHS) released the facility for unrestricted use in 1999 [DHS, 1999a]. Previous monitoring activities and results can be found in prior Annual Site Environmental Reports. 


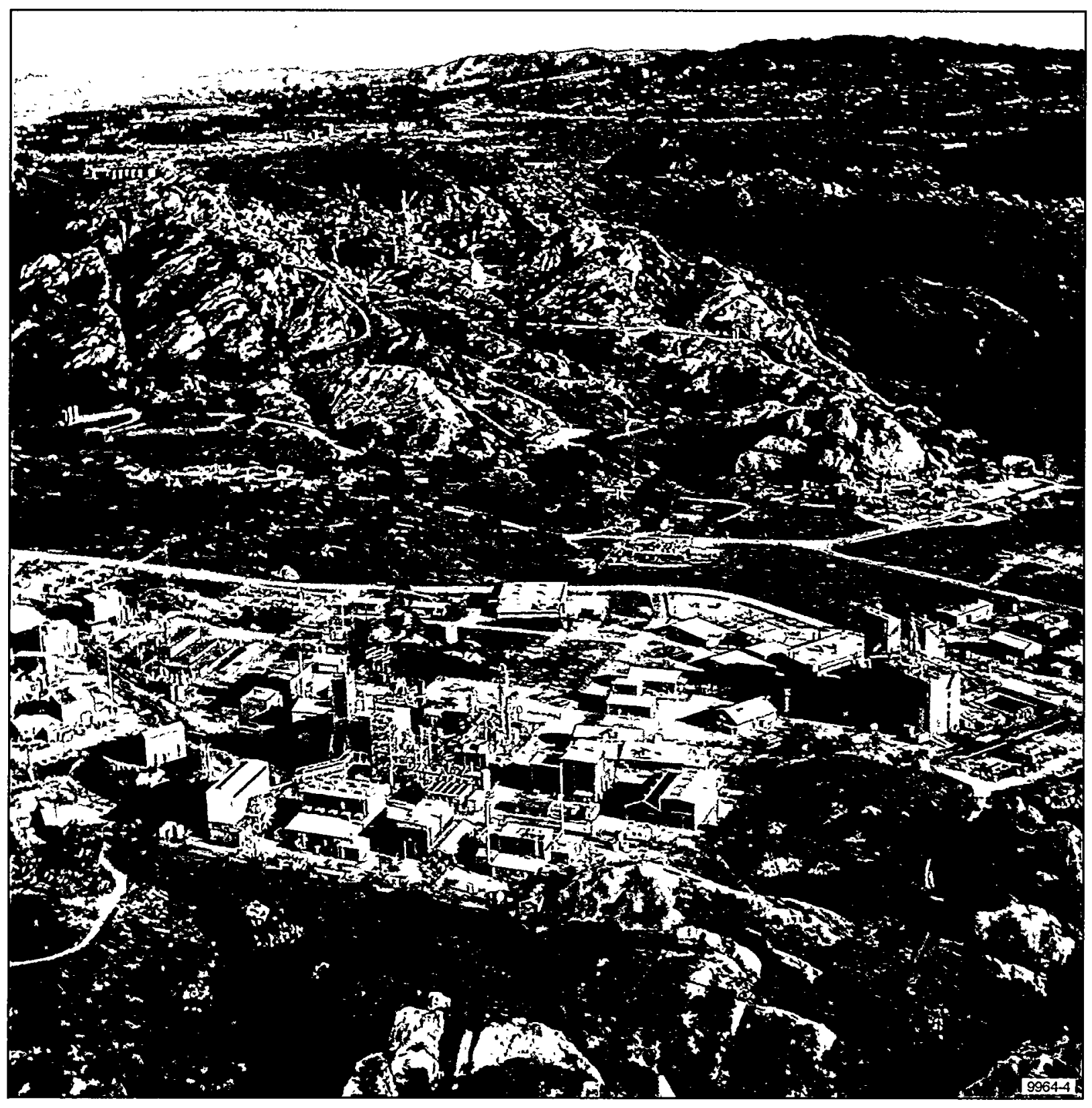

Figure 2-3. The Boeing Company, Rocketdyne-Santa Susana Field Laboratory Site, Area IV 


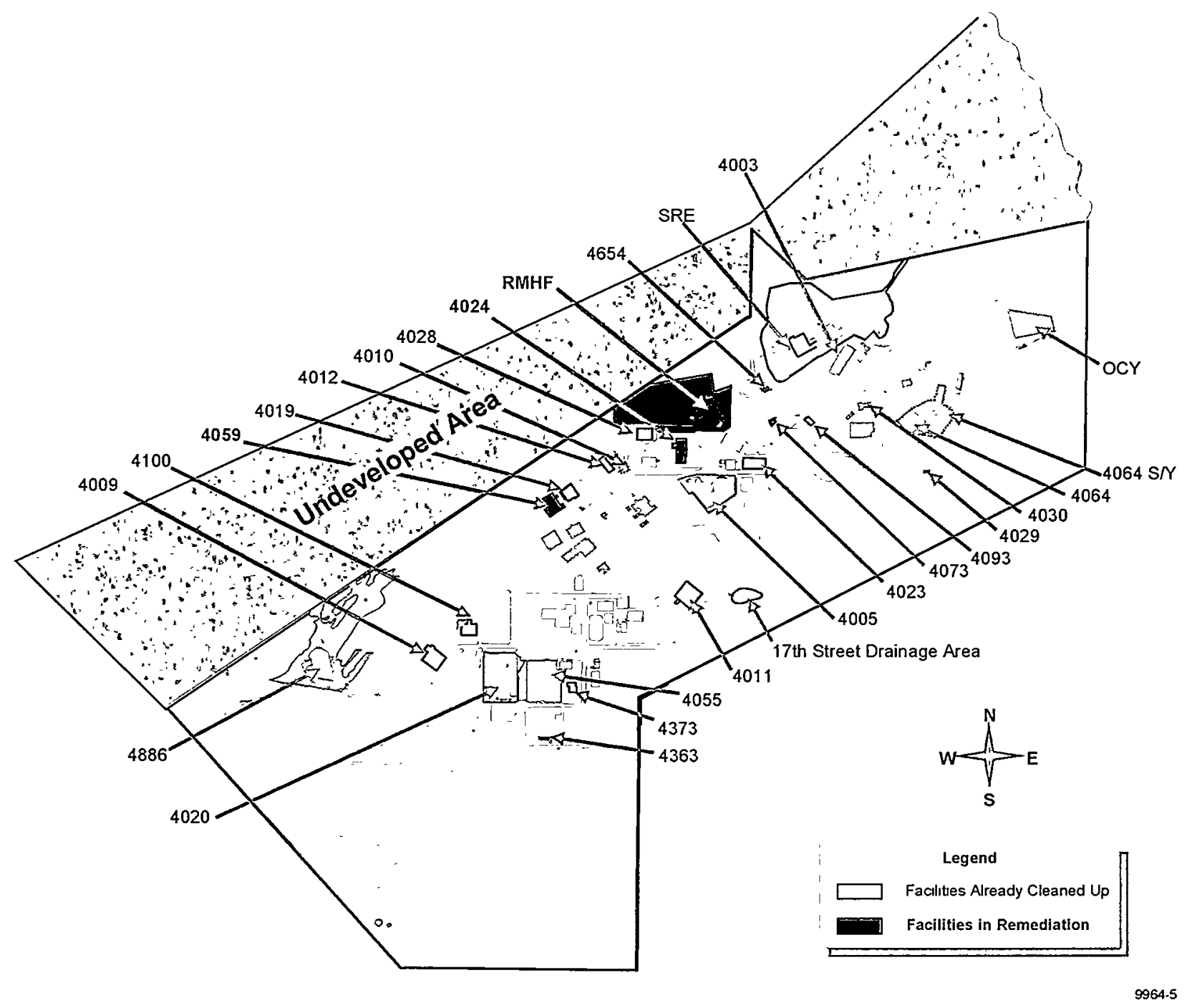

Figure 2-4. Map of Santa Susana Field Laboratory Area IV, Radiological Facilities 
RD00-159

\subsection{FACILITY DESCRIPTIONS}

These following facilities in Area IV of SSFL are undergoing cleanup for radiological and chemical, primarily sodium, contaminants.

\subsubsection{Radiological Facilities}

Figure 2-4 shows a map of the legacy radiological facilities in Area IV. Three of these 28 facilities remain to be remediated.

\section{Radioactive Materials Handling Facility (RMHF)}

The RMHF complex consists of Buildings 4021, 4022, 4034, 4044, 4075, 4621, 4658, 4665,4688 , and drainage pond 4614 . Operations at RMHF include processing, packaging, and temporary storage of radioactive waste materials, which are then shipped off-site to DOEapproved disposal facilities. Radioactive waste from decontamination operations contains uranium, transuranic elements such as plutonium, mixed fission products such as Cs-137 and Sr-90, and activation products such as $\mathrm{Co}-60, \mathrm{Eu}-152$, and tritium.

During 1999, atmospheric effluents were released through a stack as a result of the waste handling operations at the RMHF. The effluents were filtered and monitored before release into the atmosphere to ensure compliance with the National Emission Standards for Hazardous Air Pollutants (NESHAPs) requirements. No radioactive liquid effluents were released from the facility.

Groundwater was pumped throughout 1999 as part of the interim groundwater remediation program. Approximately 498,000 gallons of trichloroethylene (TCE)-contaminated groundwater were pumped and treated at the RMHF Area Interim Extraction and Treatment System (ETS) in 1999.

\section{Building 4059}

Operations at Building 4059 consist of removal of activated steel and concrete as part of the D\&D of this former Systems for Nuclear Auxiliary Power (SNAP) reactor ground test facility. Activation products consist primarily of Fe-55, Eu-152, Co-60, and minimal amounts of H-3. No radiological work requiring ventilation was performed in the building in 1999, therefore, no effluent monitoring was performed. A groundwater treatment system was installed in February 1998, and approximately 652,000 gallons of TCE-contaminated groundwater were processed in 1999 . No manmade radioactivity has been detected in this groundwater.

\section{Building 4024}

Building 4024 houses two shielded vaults in its basement. During the 1960s, this building housed two experimental reactor systems. Following termination of the projects, all equipment and fuel was removed from the facility. The shielding concrete in the vaults currently contains low levels of activation products including Co-60 and Eu-152/154. This radioactivity is confined and the radiation levels inside the vaults are a fraction of a millirem/hour. The facility is scheduled for final decommissioning and demolition in the 2002-2003 time frame. 


\subsubsection{Former Sodium Facilities}

The primary purpose of closure operations for former sodium facilities is the environmental restoration of SSFL areas and facilities that have been impacted by DOE operations. Sodium and related liquid metal test facilities were constructed at ETEC to support development testing of components for liquid metal electrical power production systems. The objective is to remove sodium and other hazardous materials from former sodium test facilities, dismantle the structural steel, concrete, and utilities, and restore the land to previous conditions. The stainless steel sodium loops including the piping, equipment, and structures are to be removed. Foundations, pits, and utilities will be removed. The resultant earth voids will be backfilled and the former sodium facility sites restored.

\section{Buildings 4355/4356 (SCTI)}

The Sodium Components Test Installation (SCTI) includes buildings 4355, 4356, 4357, $4358,4359,4360,4361$, and 4392 . The complex consists of two adjoining test stands constructed of structural steel and concrete. Two steam generator test articles containing residual amounts of sodium are installed. Removal of sodium containing piping and components continued throughout 1999. Four sodium drain tanks were cleaned in situ using a Wet-Vapor-Nitrogen (WVN) process. The H-1 Sodium Heater, E-8 Sodium Cooler, and P-5 Sodium Pump were dismantled in 1999. The backyard steam, feedwater, and cooling water systems were demolished. Buildings 4360 and 4361 were demolished and the structural steel recycled. The tiein to the Power Pak Co-generation facility was severed. The SCTI Cooling Tower was demolished.

\section{Buildings 4026/4226/4826 (SCTL)}

Buildings 4026, 4226, and 4826 comprised the Sodium Components Test Loop (SCTL) complex. This facility was used to test small components such as valves and pumps utilizing liquid sodium flowing through stainless steel piping. All sodium-containing components were removed in previous years. In 1999, the WVN cleaning of sodium piping and components was completed. Sodium hydroxide generated from the WVN process was recycled and the clean steel was sold as scrap. The facility was demolished and the steel recycled as scrap. The foundations, pits, and utilities were removed. At the end of 1999, a void remained where the concrete pits and foundations were removed. Back filling with soil and site restoration is planned for 2000 .

\section{Building 4032 (LMDL-1)}

Building 4032 housed the Liquid Metal Development Laboratory 1 (LMDL-1), which carried out applied research in support of liquid metal cooled electrical power systems. All LMDL-1 sodium piping and equipment have been removed and the facility is being used for storage and component size reduction in support of the WVN cleaning. 


\section{Area 4886 (FSDF)}

The Former Sodium Disposal Facility (FSDF) upper and lower ponds and surrounding areas work scope includes the excavation, replacement, and compaction of soil to restore the site to its original condition. Activities include continuing maintenance of the area, rainwater management, and support of closure activities. Site closure is contingent on obtaining regulatory approval and includes complete removal of the remaining chemically contaminated soil, processing final closure with the regulatory agencies, backfilling the site with clean soil, and replacement of the vegetation to blend with the surrounding area. Additional chemical remediation of FSDF was initiated in April 2000. 
RD00-159

This page intentionally left blank. 


\section{COMPLIANCE SUMMARY}

This section summarizes Rocketdyne's compliance with federal, state, and local environmental regulations. Two main categories are presented: Section 3.1 discusses compliance status, and Section 3.2 discusses current issues and actions.

\subsection{COMPLIANCE STATUS}

A list of inspections, audits, and site visits by the various agencies overseeing the SSFL sites is given in Table 3-1. No NOVs were issued as a result of these inspections and audits.

\subsubsection{Radiological}

The results of radiological environmental monitoring indicate that the SSFL does not pose any significant radiological impact on the health and safety of the general public. The applicable exposure pathways include limited atmospheric releases of radioactive materials and direct exposure during ETEC's environmental remediation and waste management operations.

\subsubsection{Airborne Activity}

Ventilation exhaust effluents from facilities at SSFL are minimized by using high efficiency particulate air (HEPA) filters. These effluents are continuously monitored by sampling the exhaust; their radioactive compositions are determined by radionuclide-specific analyses. The maximum off-site doses at the nearest residence from the effluent source are estimated by using the Environmental Protection Agency (EPA) computer program, CAP88-PC [EPA, 1992].

For the airborne releases from the RMHF exhaust stack and the Building 4024 exhaust unit, the maximum individual annual exposure was estimated at $2.2 \times 10^{-7} \mathrm{mrem} / \mathrm{yr}$. This dose is far below the limit of $10 \mathrm{mrem} / \mathrm{yr}$ and the action level of $1 \%$ of the limit $(0.1 \mathrm{mrem} / \mathrm{yr})$ as specified in 40 CFR 61, the National Emission Standards for Hazardous Pollutants (NESHAPs) Subpart $\mathrm{H}$ (DOE facilities).

The RMHF Pond (Sump 614) is a collection sump for rainfall runoff from the RMHF. When the sump is dry, sediment may be subject to airborne resuspension by wind. Although reporting this source is not a regulatory requirement, it is reported to provide complete information. During 1999, the sump was dry for approximately $\mathbf{5 0}$ days. It is assumed that the RMHF pond be a diffuse area source during the dry period, and the potential dose to the Maximally Exposed Individual (MED) was estimated to be $6.6 \times 10^{-7} \mathrm{mrem} / \mathrm{yr}$.

\subsubsection{Direct Radiation}

The external exposure rate at the Rocketdyne northern property boundary, the closest property boundary to the RMHF, was indistinguishable from natural background. This property line is approximately 300 meters from the RMHF and separated by a sandstone ridge, effectively shielding the boundary from any direct radiation from the RMHF. Dosimeters placed on the RMHF side of this sandstone ridge, approximately 150 meters from the RMHF, read an average of $54 \mathrm{mrem} / \mathrm{yr}$ above background. This is considerably below DOE's $100 \mathrm{mrem} / \mathrm{yr}$ limit. 
Table 3-1. 1999 Agency Inspections/Visits Related to Environmental Remediation

\begin{tabular}{|c|c|c|c|}
\hline Date (1999) & Agency & Subject Area & Results \\
\hline January & $\begin{array}{l}\text { DHS Radiologic Health } \\
\text { Branch }\end{array}$ & $\begin{array}{l}\text { Conduct } 4^{\text {th }} \text { Quarter thermoluminescent } \\
\text { dosimeter (TLD) Exchange }\end{array}$ & Compliant \\
\hline January & $\begin{array}{l}\text { State of CA, Radiologic } \\
\text { Health Branch }\end{array}$ & Environmental TLD exchange & Compliant \\
\hline February & VCAPCD \& Cal/OSHA & Review options for abatement at B/4143-SRE & Compliant \\
\hline March & $\begin{array}{l}\text { State of CA, Radiologic } \\
\text { Health Branch }\end{array}$ & $\begin{array}{l}\text { Verification survey of } \mathrm{B} / 020 \text { demolition } \\
\text { concrete blocks for unrestricted release }\end{array}$ & Compliant \\
\hline April & DTSC & $\begin{array}{l}\text { Inspection of mixed hazardous waste handling } \\
\text { facilities (RMHF) and programs }\end{array}$ & Compliant \\
\hline April & $\begin{array}{l}\text { State of CA, Radiologic } \\
\text { Health Branch }\end{array}$ & Environmental TLD exchange & Compliant \\
\hline June & VCAPCD & $\begin{array}{l}\text { Annual inspection of Permit to Operate } \\
\text { (Permit } 0271 \text { ) and reviewed usage logs for } \\
1998 \text { and } 1999\end{array}$ & Compliant \\
\hline June & VCAPCD & Review abatement project at $\mathrm{B} / 4143-\mathrm{SRE}$ & Compliant \\
\hline June & $\begin{array}{l}\text { DHS Radiologic Health } \\
\text { Branch }\end{array}$ & $\begin{array}{l}\text { Routine inspection of operations conducted } \\
\text { under California Radioactive Materials } \\
\text { License }\end{array}$ & Compliant \\
\hline June & $\begin{array}{l}\text { California Regional Water } \\
\text { Quality Control Board } \\
\text { (CRWQCB) }\end{array}$ & $\begin{array}{l}\text { Annual site visit and sampling for the National } \\
\text { Pollutant Discharge Elimination System } \\
\text { (NPDES) permit }\end{array}$ & Compliant \\
\hline June & VCEHD & $\begin{array}{l}\text { Verify compliance with Business Plan, } \\
\text { hazardous waste, and storm water } \\
\text { requirements }\end{array}$ & Compliant \\
\hline July & $\begin{array}{l}\text { State of CA, Radiologic } \\
\text { Health Branch }\end{array}$ & Environmental TLD exchange & Compliant \\
\hline July & $\begin{array}{l}\text { DHS Radiologic Health } \\
\text { Branch }\end{array}$ & Verification surveys of $B / 4020$ concrete blocks & Compliant \\
\hline July & $\begin{array}{l}\text { DHS Radiologic Health } \\
\text { Branch, Materials Licensing }\end{array}$ & $\begin{array}{l}\text { Post survey of B/104, Mass Spec Lab, and } \\
\text { Gamma Irradiation Facility to remove from } \\
\text { Radioactive Materials License }\end{array}$ & Compliant \\
\hline September & VCAPCD & $\begin{array}{l}\text { Review abatement project for SABER Facility } \\
\text { control center and Specialized } \\
\text { Environmental's Demo Pack } 7\end{array}$ & Compliant \\
\hline October & $\begin{array}{l}\text { State of CA, Radiologic } \\
\text { Health Branch }\end{array}$ & Environmental TLD Exchange & Compliant \\
\hline October & $\begin{array}{l}\text { DHS Radiologic Health } \\
\text { Branch }\end{array}$ & $\begin{array}{l}\text { Verification surveys of } B / 4020, B / 4059,17^{\text {th }} \\
\text { Street Drainage Area, and } B / 4133\end{array}$ & Compliant \\
\hline November & $\begin{array}{l}\text { ETEC Site Office and CHP } \\
\text { DOE-OAK }\end{array}$ & $\begin{array}{l}\text { Readiness review for implementation of } 10 \\
\text { CFR } 835 \text { and Radiation Protection Plan }\end{array}$ & Compliant \\
\hline
\end{tabular}




\subsubsection{Groundwater}

All liquid radioactive wastes are processed by either solidification or evaporation prior to disposal at DOE disposal sites. Liquid radioactive wastes are not released into the environment and do not constitute an exposure pathway. Groundwater and surface water in Area IV are sampled and analyzed to assure detection of any non-natural radioactivity.

At SSFL, there are 243 groundwater monitoring wells in the monitoring system; of which, 45 are located in Area IV. Groundwater is sampled and analyzed periodically for non-naturally occurring radionuclides. During 1999, no man-made radionuclides were found in the groundwater samples except for a few positive identification of tritium. The positive tritium identifications had maximum concentrations of $294,401,650$, and $697 \mathrm{pCi} / \mathrm{L}$ at wells $\mathrm{RD}-23$, $\mathrm{RD}-24, \mathrm{RD}-34 \mathrm{~B}$, and $\mathrm{RD}-54 \mathrm{~A}$, respectively.

Extracted groundwater from the French drain at Building 4059 is periodically sampled and analyzed by gamma spectroscopy. The purpose of this analysis is to detect any potential leakage of the fission products, namely $\mathrm{Co}-60$ and $\mathrm{Eu}-152$, from the underground reactor vault in Building 4059 to the groundwater. In 1999, two water samples were taken and analyzed; neither Co-60 nor Eu-152 was detected in those samples. In fact, no man-made radionuclides were detected in these samples.

\subsubsection{Surface Water}

Surface water from two National Pollutant Discharge Elimination System (NPDES) discharge points and five storm water runoff catch basins are also monitored routinely. The Rocketdyne NPDES permit allows excess water, including reclaimed wastewater, runoff water from retention due to heavy precipitation, and runoff water from the northwest slop of Area IV, to discharge into Bell Creek, a tributary to the Los Angeles River. Excess reclaimed water, including treated sanitary sewage and runoff from Area IV, is now discharged on a continuous basis through the R-2A outfall location (Outfall 002). Discharge along the northwest slope of Area IV (Outfalls 003 through 007) generally occurs only during and after periods of heavy rainfall. The permit applies the numerical limits for radioactivity in drinking water supplies to drainage through these outfalls. The permit requires radiological measurements of gross alpha, gross beta, tritium, Sr-90, and total combined Ra-226 and Ra-228. In 1999, 17 water samples were taken for NPDES permit compliance; no samples exceeded drinking water supplier limits for radioactivity.

\subsubsection{Chemical}

\subsubsection{Resource Conservation and Recovery Act}

The Resource Conservation and Recovery Act (RCRA) gives the Environmental Protection Agency (EPA) broad authority to regulate the handling, treatment, storage, and disposal of hazardous wastes. DOE owns and co-operates two RCRA-permitted Treatment, Storage, and Disposal Facilities with ETEC. No Notices of Violations (NOV) were issued during 1999. Permit numbers are listed in Section 3.1.4. 


\subsection{RMHF}

In 1999, the RMHF continued to operate as an Interim Status (Part A) permitted facility. This facility is used primarily for the handling and packaging of radioactive waste. Interim status is required for the storage and treatment of the small quantities of mixed waste (waste containing both hazardous and radioactive constituents) resulting from D\&D activities at ETEC. The final disposition of mixed waste is addressed under the DOE and DTSC-approved Site Treatment Plan, which is authorized by the Federal Facilities Compliance Act (FFCA).

In July 1998, the California EPA DTSC requested the completion of the RCRA permitting process for RMHF. Completion of the RCRA permitting involves the creation of an Operations Plan document and following public comment and agency approval, the issuance of a Part B permit by the DTSC. A draft Operations Plan was submitted to DTSC in May 1999. In February, 2000, the DTSC issued a Notice of Deficiency (NOD) for the Operation Plan. A response to the NOD is expected to be returned to the DTSC by mid-2000.

\subsection{HWMF}

The Hazardous Waste Management Facility (HWMF) includes a storage facility (Bldg 4029) and a treatment facility (Bldg 4133) for reactive metal waste such as sodium. In 1998, the facility entered final closure and is no longer operated. A closure plan was submitted to the DTSC in January 1999. The work performed in 1999 included processing of the RCRA Facility Closure Plan and coordination with regulatory agencies.

\subsection{Sodium Removal}

Removal of metallic sodium from the closed facilities continued in 1999. Removal of sodium is accomplished by bulk transfer and by conversion of metallic sodium into usable sodium hydroxide. The bulk sodium and piping residuals are managed as an "excluded recyclable material" in accordance with applicable regulations. In 1999, a total of $16,018 \mathrm{lb}$ of surplus sodium were removed from Area IV. As of December 1999, approximately 5,800 lb of surplus sodium were left for removal. At the time of publication, the amount of surplus sodium left on-site had been reduced to $1,600 \mathrm{lb}$. In addition to the surplus sodium, approximately 40,000 gallons of sodium are in use at the Sodium Pump Test Facility (SPTF). The sodium in use will be removed from the site when the test is completed.

\subsection{RCRA Facility Investigation (RFI)}

Under the Hazardous and Solid Waste Amendments of 1984, RCRA facilities can be brought into the corrective action process when an agency is considering any RCRA permit action for the facility. The SSFL was initially made subject to the corrective action process in 1989 by EPA, Region IX. The EPA has performed the Preliminary Assessment Report and the Visual Site Inspection portions of the RCRA Facility Assessment (RFA) process.

The State of California DTSC has RCRA authorization and has become the lead agency in implementing the corrective action process for the SSFL. ETEC has performed soil sampling at various Solid Waste Management Units (SWMU) and Areas of Concern (AOC) identified in the RFI Work Plan. 
The current conditions report and a draft of the RFI Work Plan for the Area IV SWMUs were submitted to the DTSC in October 1993. In November 1996, DTSC approved a revised work plan addendum. Fieldwork in areas of unrestricted use began in November 1996 and is scheduled for completion in 2000.

Fieldwork in 1999 included collecting soil samples from the Old Conservation Yard(SWMU 7.4), Building 4056 landfill/excavation (SWMU 7.1), B100 Trench (SWMU 7.5), and the Southeast Drum Storage. To date, approximately 20 soil vapor and 166 soil matrix samples have been collected and analyzed. The chemical analysis was performed by State certified laboratories and validated by Ogden Environment, the RFI contractor. At DTSC's request, Boeing submitted the RCRA Facility Preliminary Soil Sampling Results, dated December 1999. The purpose of the submittal was to share RFI data (collected through December 1998) with DTSC in an effort to facilitate DTSCs review of the data and to share information with the public.

In addition, Boeing continued to revise the Standardized Risk Assessment Methodology (SRAM) based on DTSC comments. Approval of the SRAM is anticipated during 2000.

\subsection{Groundwater}

Characterization of the groundwater at the site continues. TCE continued to be detected in three areas of Area IV during 1999 at concentrations ranging from Not Detected (ND) to 2,000 $\mu \mathrm{g} / \mathrm{L}$ in shallow zone and ND to $560 \mu \mathrm{g} / \mathrm{L}$ in Chatsworth Formation. The high concentrations were detected in three areas inside the northwestern property boundary, as shown in the shaded areas in Figure 6-3.

\subsubsection{Federal Facilities Compliance Act}

ETEC is managing its modest inventory (currently less than $18 \mathrm{~m}^{3}$ ) of RCRA mixed wastes in accordance with the FFCA-mandated Site Treatment Plan approved in October 1995. During CY99, the number of mixed waste streams with active volumes in storage were reduced from 10 to 4 by shipping two waste stream inventories to an off-site facility for treatment and disposal, and by completing on-site treatment of four waste stream inventories to meet Land Disposal Restriction (LDR) treatment standards. These activities resulted in a reduction of approximately $1 \mathrm{~m}^{3}$ in mixed waste inventories. All mixed wastes that require on-site storage beyond the regulatory (i.e., per RCRA) allowed time limits are managed within the framework of the STP. Characterization, treatment, and disposal plans for each of several different waste streams are defined in the STP with enforceable milestones. These include characterization, reporting, study of treatment options, shipping schedules, and actual removal. ETEC has met all STP milestones to date. Regular updates to reflect changes in inventory or status of mixed wastes and certifications of milestone completion are submitted to DTSC in accordance with the STP.

\subsubsection{National Environmental Policy Act}

The National Environmental Policy Act (NEPA) establishes a national policy to ensure that consideration is given to environmental factors in federal planning and decision-making. For those projects or actions expected to either affect the quality of the human environment or create controversy on environmental grounds, DOE requires that appropriate NEPA actions 
(Categorical Exclusion [CX], Environmental Assessment [EA], Finding of No Significant Impact [FONSI], or Notice of Intent [NOI], draft Environmental Impact Statement [EIS], final EIS, Record of Decision [ROD]) have been incorporated into project planning documents. DOE has implemented NEPA as defined in Federal Register Volume 57, Number 80, pages 15122 through 15199 and in accordance with the DOE O 451.1A.

Environmental impacts of each new project are assessed. Based on the assessments, DOE is requested to issue determinations of compliance to the NEPA. Requests for NEPA determinations for the following six new projects were submitted in the calendar year 1999:

- Dismantling, Removal and Site Restoration of Fuel Oil Storage and Distribution System

- Dismantling of LMDL-2 Sodium system

- Dismantling, Removal and Site Restoration of Demo Pak A

- Dismantling, Removal of SABER

- Demolition, Removal and Site Restoration of Miscellaneous Structures and Appurtenances

- Demolition, Removal and Site Restoration of Power Pak/Co-Generation Facility

Categorical exclusions for these six projects were approved by DOE in CY99. There were no draft or final environmental impact statements or reports, site assessments, or remedial action reports produced during 1999.

No actions were taken by local authorities and no NOVs were relative to the Comprehensive Environmental Response, Compensation, and Liability Act (CERCLA)/ Superfund Amendments and Reauthorization Act (SARA) activities for the DOE area.

\subsubsection{Clean Air Act}

The Clean Air Act (CAA) resulted in federal regulations that set air quality standards and required state implementation plans (SIPS), National Emissions Standards for Hazardous Air Pollutants (NESHAPs), New Source Performance Standards (NSPS), and monitoring programs in an effort to achieve air quality levels beneficial to the public health and welfare. The SSFL is regulated by the Ventura County Air Pollution Control District (VCAPCD) and must comply with VCAPCD Rules and Regulations. The EPA can enforce VCAPCD rules and also regulates pollutants such as Ozone Depleting Substances (ODS) under 40 CFR 82.

\subsubsection{Clean Water Act}

The Clean Water Act (CWA) is the primary authority for water pollution control programs, including the National Pollutant Discharge Elimination System (NPDES) permit program. The NPDES program regulates point source discharges of surface water to drainage channels (i.e., to locations other than sewage systems), and the discharge of storm water runoff associated with 
industrial activities. Basin Plan water quality objectives are applied as effluent standards for offsite discharge of storm and industrial wastewater via the SSFL water reclamation system.

Surface water discharges from SSFL are regulated under the California Water Code (Division 7) as administered by the California Regional Water Quality Control Board (CRWQCB). The existing NPDES Permit (CA0001309) for SSFL, which was revised and became effective June 29, 1998, is expected to remain in force through May 10, 2003. The revised NPDES Permit incorporated the General Permit (No. CAS000001) for storm water, which includes the requirement for a site-wide Storm Water Pollution Prevention Plan (SWPPP). The SWPPP is revised as needed and includes by reference many existing pollution prevention plans, policies, and procedures implemented at the SSFL site. Several key elements of the plan, including maps, are continually updated. Another key element is the Rocketdyne procedure "SSFL Storm Water Pollution Prevention Requirements." The Spill Prevention Control and Countermeasure (SPCC) plan serves to identify specific procedures for handling oil and hazardous substances to prevent uncontrolled discharge into or upon the navigable waters of the State of California or the United States. The U.S. EPA requires the preparation of an SPCC plan by those facilities that, because of their location, could reasonably be expected to discharge oil in harmful quantities into or upon navigable waters. A revised SPCC plan was submitted as a part of the revised Spill Prevention and Response Plan to the local Administering Agency on March $20,2000$.

Sewage from Area IV (including DOE facilities) is treated at the Area III Sewage Treatment Plant (STP), which discharges to the R2A Pond. Most surface runoff from Area IV also drains to R2A Pond. The northwest slope of Area IV drains through five small catch basins. During periods of rainfall, and when there is adequate runoff for sampling, grab samples of surface water runoff are collected at the outfalls. Samples are collected no more than twice a month (biweekly) per outfall during the rainy season. In the dry season, if discharges occur on a continual basis, samples are collected monthly. The sampling performed at the five northwest slope locations includes quarterly monitoring for a list of analytes referred to as "priority pollutants." There was no NOVs of the NPDES permit in 1999.

\subsubsection{Former Sodium Disposal Facility Closure Order}

Chemical analyses of soil have indicated the continued presence of residual chemical contaminants in the upper basin, western area, and drainage channels. The contaminants of concern were polychlorinated biphenyls (PCB), dioxins, and mercury. As a result, interim measures have been implemented after consultation with the DTSC, including establishment of sediment weirs downslope of the facility. A health-based risk assessment has been performed and was approved by DTSC on July 15, 1999. An interim measure workplan consisting of excavation, backfilling, and re-vegetation has been proposed to DTSC. DTSC held a meeting on July 28, 1999 to receive public comment on the proposed workplan. Approval of the interim measure workplan was received and excavation of the chemicals was initiated in April 2000.

\subsubsection{Public Participation}

During 1999, Rocketdyne has continued and expanded its commitment to community involvement by hosting seven homeowners association and community meetings and three bus tours at the Santa Susana Field Laboratory (SSFL). These activities provided a two-way 
exchange of information for more than 800 community members. Rocketdyne staff members and technical experts were on hand with display boards and exhibits to enhance understanding of the technological and scientific mission at SSFL as well as all environmental programs at the facility. Surveys indicated a very positive response to these meetings and sharing of information. Rocketdyne also supported seven regulatory agency-sponsored meetings as well as six meetings with local elected officials.

Rocketdyne produced and distributed three fact sheets (1) Santa Susana Field Laboratory: An Environmental Overview, (2) Santa Susana Field Laboratory: Groundwater Cleanup and Monitoring Program, and (3) Santa Susana Field Laboratory: Radioactive Materials Handling Facility (RMHF).

In addition to these efforts, Rocketdyne partnered with Friends of the Los Angeles River for the $10^{\text {th }}$ Annual Great Los Angeles River Clean-up; the City of Los Angeles for the Countywide Household Hazardous Waste Collection Program-_Hazmobile" event; and a local elementary school and grocer for Earth Day 1999.

Rocketdyne implemented the Think Earth environmental educational enrichment program at a local elementary school. Lessons focus on helping students become more aware about their environment and learning to reduce, reuse, or recycle.

In support of the Rocketdyne Educational Outreach program, the SSFL Council hosts several teacher and student tours each year at the field lab. The tours provide an opportunity for the teachers and students to see the historical site and talk to scientists and engineers involved in field lab programs.

Rocketdyne continues to supply three local repositories with information on environmental remediation projects at the site. In addition, Rocketdyne catalogues and inventories the documents at two of these repositories.

Rocketdyne maintains a community mailing list of about 1,500 people and distributes information to these community members as part of our ongoing community outreach activities and on behalf of the regulatory agencies. 


\subsubsection{Permits and Licenses (Area IV)}

Listed below are the permits and licenses applicable to activities in Area IV'.

\begin{tabular}{|c|c|c|}
\hline Permit/License & Facility & Valid \\
\hline \multicolumn{3}{|c|}{ Air (VCAPCD) } \\
\hline Permit 0271 & Combined permit renewal & $1 / 1 / 98$ through $12 / 31 / 00$ \\
\hline \multicolumn{3}{|c|}{ Treatment Storage (EPA) } \\
\hline $\begin{array}{l}\text { CAD000629972 } \\
(93-3-T S-002)\end{array}$ & $\begin{array}{l}\text { Hazardous Waste Management Facility } \\
\text { (T133 and T029) }\end{array}$ & Inactive: closure announced \\
\hline СА3890090001 & $\begin{array}{l}\text { Radioactive Materials Handling Facility } \\
\text { (RMHF) }\end{array}$ & $\begin{array}{l}\text { Part A interim status December } \\
\text { 1997. Application for Part B } \\
\text { submitted May } 1999 .\end{array}$ \\
\hline \multicolumn{3}{|c|}{ NPDES (CRWQCB) } \\
\hline CA0001309 & Santa Susana Field Laboratory & $6 / 29 / 98$ through $5 / 10 / 03$ \\
\hline \multicolumn{3}{|c|}{ State of California } \\
\hline $\begin{array}{l}\text { Radioactive Materials License } \\
(0015-19)\end{array}$ & All Rocketdyne facilities & $\begin{array}{lc}\text { Amendment } & \text { Issued } \\
102 & 1 / 13 / 99 \\
103 & 8 / 2 / 99 \\
104 & 3 / 2 / 00 \\
\text { Ongoing } & \end{array}$ \\
\hline
\end{tabular}

During 1999, five underground storage tanks (UST) were exempt from permitting in Area IV. A list of these tanks is shown in Table 3-2.

Table 3-2. SSFL Current Underground Storage Tanks

\begin{tabular}{|c|c|c|c|c|}
\hline UST & $\begin{array}{c}\text { Building } \\
\text { Location }\end{array}$ & $\begin{array}{c}\text { Capacity } \\
\text { (gallons) }\end{array}$ & Tank Type & Contents \\
\hline UT-7 & T022 & 3,000 & Stainless Steel Vaulted & RA water ${ }^{\mathrm{a}}$ \\
\hline UT-15 & T022 & 8,000 & Stainless Steel Vaulted & RA water $^{\mathrm{a}}$ \\
\hline UT-16 & T021 & 200 & Stainless Steel Vaulted & RA water \\
\hline UT-34 & T462 & 36,000 & Stainless Steel Vaulted & Sodium $^{\mathrm{b}}$ \\
\hline UT-35 & T462 & 34,000 & Stainless Steel Vaulted & Sodium $^{\mathrm{b}}$ \\
\hline $\begin{array}{l}{ }^{\mathrm{a}} \text { Radioactive (RA) water tanks are regulated by U.S. Department of Energy (DOE). } \\
\text { bSodium tanks are exempt from UST permitting per Ventura County Environmental Health Division. }\end{array}$ \\
\hline
\end{tabular}

\footnotetext{
${ }^{1}$ The waste discharge requirements for the sewage treatment plan in Area III that receives the Area IV sewage are included in the NPDES permit.
} 


\subsection{CURRENT ISSUES AND ACTIONS}

\subsubsection{Progress in Radiological Decommissioning Operations}

\subsubsection{1999 Status of Building Release}

In 1999, the State Department of Health Services Radiologic Health Branch (DHS/RHB) released and/or concurred with the release of two buildings at the Rocketdyne SSFL for unrestricted use. This followed extensive radiological surveys by both Rocketdyne and the DHS/RHB to verify that the buildings posed no further radiological hazard.

The released facilities were the van de Graaff Accelerator Facility (Bldg 4030) [DHS, 1999b; FR, 1997] and the Organic Moderated Reactor/Sodium Graphite Reactor (Bldg 4009) [DHS, 1999c]. The State DHS/RHB also removed the Hot Lab (Bldg 4020) from the Rocketdyne Radioactive Materials License [DHS, 1999c].

Rocketdyne is currently waiting DHS concurrence for release of the interim storage facility (Bldg 4654), the Building 4064 sideyard, and SNAP Flight System Critical Facility (Bldg 4019). Certification packages for each of these buildings have been sent to the DOE.

\subsubsection{1999 Final Survey Status}

\subsection{Area 4020 (Hot Lab)}

Following demolition of the Hot Lab facilities in 1996 though 1998, the remaining land was subjected to a final status survey. In 1999, the remaining land was gridded, surveyed, and sampled as part of the final status survey following new Multi-Agency Radiation Survey and Site Investigation Manual (MARSSIM) [NRC, 1997] protocols in the summer of 1999 [Liddy 1999a]. This was followed by verification surveys by Oak Ridge Institute for Science and Education (ORISE) and the California DHS in October 1999. These surveys demonstrate that DOE and DHS soil cleanup standards have been met, and that no residual contamination remains that could result in any exposure or risk to current or future users. The land is therefore suitable for unrestricted use. After the ORISE verification report, Rocketdyne will request that DOE release the land for unrestricted use.

\subsection{Building 4059 (SNAP Test Facility)}

In Phase I, the above grade portion of Building 4059 and the underground non-activated portions of the basement were D\&D'd and final surveyed, by Rocketdyne in June 1999 [Liddy 1999b]. MARSSIM protocols were used for the survey. This portion of the building then underwent verification surveys by the ORISE and the California DHS in October of 1999. It is anticipated that this part of the building will be released for unrestricted use in 2000. Demolition is scheduled for 2001. The remaining activated concrete in the underground test vault will then be removed and disposed of as radioactive waste. The remaining hole will then be soil sampled by Rocketdyne as part of a final survey; and ORISE and DHS will then perform verification soil sampling. Assuming results show no residual contamination, the facility will be released for unrestricted use and the excavation backfilled and graded. 


\subsubsection{3 $17^{\text {th }}$ Street Drainage Area}

The $17^{\text {th }}$ Street Drainage Area was a bermed pond used to control surface water runoff from Area IV during the 1960s. As a result of cyclic filling and evaporation over the years, low levels of cesium and thorium were built up. The 1998 Site Environmental Report [Rocketdyne, 1999] summarizes the sampling and decontamination. In 1999, a final survey of this area was performed by Rocketdyne, using MARSSIM protocols [NRC, 1997]. Verification surveys by the ORISE and the California DHS were completed in October 1999. These surveys demonstrate that DOE and DHS soil cleanup standards have been met, and that no residual contamination remains that could result in any exposure or risk to current or future users. The land is therefore suitable for unrestricted use. It is anticipated that the State will release the facility for unrestricted use in 2000.

\subsection{Building 4133 (Hazardous Waste Management Facility-HWMF)}

The HWMF is a permitted hazardous waste treatment facility that was used for treating metallic sodium and $\mathrm{NaK}$ and converting into $\mathrm{NaOH}$ and $\mathrm{KOH}$. A work plan for closure of this facility is currently being reviewed by the Department of Toxic Substances Control (DTSC). The HWMF was not operated as a radiological facility and radioactive materials were not used at the HWMF.

To verify that the HWMF had not been affected by radiological operations, it was determined that a complete radiation survey would be performed of the facility building, fenced land, and two acres of surrounding land. This would allow the permitted facility closure process to proceed without further concern for radiological constituents. This survey [Liddy, 1999c] was completed in August-September 1999 and included measurements for total and removable surface contamination of facility surfaces, radiation exposure measurements of land surfaces, radiation exposure measurements at 1 meter, and soil samples at surface and at depth. The survey demonstrated that the facility contained no detectable activity above background. The survey further demonstrated that soil surrounding the facility met DOE- and DHS-approved cleanup standards. In October 1999, ORISE and DHS performed verification surveys of this facility verifying that the facility is not radiologically contaminated.

\subsubsection{Agency for Toxic Substances and Disease Registry}

In September 1999, a 12-person team from the Agency for Toxic Substances and Disease Registry (ATSDR) spent a week conducting interviews and document review at SSFL. This investigation was a result of a petition from Senators Feinstein and Boxer to the Department of Health and Human Services to initiate a community health study in the communities surrounding Santa Susana. This visit also included two public meetings at which the ATSDR solicited input from the community and a visit to the office of the Committee To Bridge The Gap.

On November 15, 1999, the ATSDR released its preliminary findings on its assessment of the Rocketdyne Santa Susana Field Laboratory. 
RD00-159

The ATSDR concluded that, quote:

- "Available data provide no indication that municipal and privately owned water wells have been affected by chemicals from the site."

- "There is currently no indication that off-site residential areas have been adversely impacted by materials from the site."

- "Based on our initial review of existing data on possible pathways of exposure from the site, we have not seen that people in local communities have been exposed to substances from the site at levels that would result in adverse health effects."

The community should be reassured by this investigation. The ATSDR has concluded that, based on its preliminary investigation, it has found no evidence that Rocketdyne operations have adversely effected the environment or the health of its neighbors. ATSDR joins a long list of agencies, including DHS, EPA, and DTSC that have reached the same conclusion. We are confident that any further studies proposed by ATSDR will reach a similar conclusion.

To further confirm these findings the ATSDR is recommending further studies:

- More in-depth assessment of exposure pathways, including

- Airborne chemical releases

- Additional monitoring of springs and seeps

- Further radiological survey/sampling of Area IV of SSFL

- Reanalysis of cancer registry data

The ATSDR later issued its Preliminary Site Evaluation on December 3, 1999 [ATSDR, 1999]. In its report, the ATSDR stated ...

- "Extensive monitoring also indicates that radiation in the areas of potential off-site exposure has not been detected above background."

- "In this preliminary evaluation of available data and information, ATSDR has not identified an apparent public health hazard to the surrounding communities because people have not been, and are currently not being exposed to chemicals and radionuclides from the site at levels that are likely to result in adverse health effects."

- "Based on available data and information, there is no indication that off-site residential areas, including the Brandeis-Bardin Institute, the Santa Monica Mountains Conservancy, and Bell Canyon, have been adversely impacted by chemicals or radionuclides from SSFL."

The complete ATSDR report documenting ATSDR's conclusions regarding Santa Susana may be found on the web at http://www.atsdr.cdc.gov/HAC/PHA/santa/san toc.html. 


\section{ENVIRONMENTAL PROGRAM INFORMATION}

At SSFL, the "DOE Site Closure" department has programmatic responsibility for the former radiological facilities, former sodium test facilities, and related cleanup operations. "DOE Site Closure" is responsible for environmental restoration and waste management operations in Area IV, where DOE-funded programs conducted energy-related research and development (R\&D). Environmental restoration activities include decontamination and decommissioning (D\&D) of radioactively contaminated facilities, building demolition, treatment of sodium, assessment and remediation of soil and groundwater, surveillance and maintenance of work areas, and environmental monitoring. Waste management activities include waste characterization and certification, storage, treatment, and off-site disposal. Waste management activities are performed at the Radioactive Materials Handling Facility (RMHF) for radioactive and mixed waste. The Hazardous Waste Management Facility (HWMF) has been used to handle alkali metal waste, but it is currently inactive and undergoing closure.

\subsection{ROCKETDYNE ENVIRONMENTAL PROTECTION AND REMEDIATION}

Oversight of the environmental protection at Rocketdyne is the responsibility of the Safety, Health \& Environmental Affairs (SHEA) department, and this department provides support for environmental management and restoration. The stated policy of SHEA is "To support the Corporation's commitment to the well-being of its employees, community, and environment. It is Rocketdyne's policy to maintain facilities and conduct operations in accordance with all federal, state, and local requirements and contractual agreements. Rocketdyne employees are responsible for implementing and complying with this policy." Responsibilities for environmental protection at Rocketdyne fall under four subdepartments: Environmental Protection (EP), Radiation Safety (RS), Environmental Remediation (ER), and DOE Site Restoration. The responsibilities for each are listed below.

Environmental Protection (EP) is responsible for developing and implementing costeffective and efficient programs designed to ensure achievement of the policy objectives related to environmental protection. The $\mathrm{EP}$ responsibilities include:

- $\quad$ Ensuring compliance with applicable federal, state, and local rules and regulations, including maintaining a working knowledge of applicable environmental laws, performing compliance audits, reviewing new and modified facility projects, coordinating solid and hazardous waste disposal, maintaining required records, preparing and submitting required regulatory reports, applying for and maintaining permits and assuring compliance with permit conditions, performing sampling and analysis.

- Responding to uncontrolled releases, and reporting releases as required by law and contractual requirements.

- Suspending operations determined to be in violation of environmental regulations.

- Participating in rule and regulatory development, including evaluating impacts on Rocketdyne programs, coordinating with other Rocketdyne functions, as appropriate, and informing management and staff of new or revised requirements. 
- Providing a program in conjunction with Technical Skills and Development for motivating, informing, and training employees about their duties to comply with environmental regulations and protect the environment.

- Recognizing and responding to the community's concerns regarding the environmental impact of Rocketdyne operations including escorting and cooperating with regulatory officials interested in environmental matters and responding to requests for information referred to Communications.

- Working with Rocketdyne customers and suppliers to minimize the use of materials and processes that impact the environment while maintaining product quality and competitive pricing.

- Making environmental concerns, energy and raw material conservation a priority when evaluating new and existing operations and products, or when making decisions regarding land use, process changes, materials purchases, and business acquisitions.

Radiation Safety (RS) is responsible for providing radiological support for the D\&D of radiological contamination at all Rocketdyne facilities. The RS responsibilities include:

- Compliance with all federal, state, and local regulations pertaining to occupational and environmental radiation protection.

- Provision of health physics oversight of D\&D and radioactive waste management activities.

- Performance of final surveys of D\&D'd buildings and facilities to demonstrate acceptability for release for unrestricted use.

- Response to employee and public concerns regarding radiological activities and the impact of these activities on the health and safety of the community.

Environmental Remediation (ER) is responsible for remedial actions to clean up historical chemical contamination at all Rocketdyne facilities. The ER responsibilities include:

- Compliance with all federal, state, and local regulations pertaining to environmental remediation.

- Remediation of historical chemically contaminated Rocketdyne sites to achieve closure.

- Implementation of groundwater monitoring and treatment.

- Implementation of RCRA soil sampling and cleanup activities. 
DOE Site Restoration is responsible for performing the "hands on" D\&D of former DOE nuclear and liquid metal test facilities in support of the DOE Closure program. DOE Site Restoration responsibilities also include:

- Responsibility for the management and shipment of radioactive waste, generated during the D\&D operations, to DOE-approved disposal sites.

- Operation of the Radioactive Materials Handling Facility (RMHF) under an interim status Part A permitted facility for the management of mixed (radioactive and hazardous) wastes.

- Coordination of activities with specialty contractors used to support D\&D activities including asbestos and lead abatement, recycling of sodium from former liquid metal facilities, and demolition of structures following removal of hazardous materials and components.

- Performance of the routine Surveillance and Maintenance (S\&M) activities for DOEowned facilities to ensure that the buildings are properly maintained such that the buildings do not create personnel or environmental safety hazards.

- Responsibility for identifying, removing, staging, and initiating documentation for DOE equipment being divested.

\subsection{ENVIRONMENTAL MONITORING PROGRAM}

The purpose of the environmental monitoring program is to detect and measure potential releases of hazardous and radioactive materials and identify other undesirable impacts on the environment. It includes remediation efforts to correct or improve contaminated conditions at the site and prevent off-site effects. For this purpose, the environment is sampled and monitored, and effluents are analyzed. A goal of this program is to demonstrate compliance with applicable regulations and protection of human health and the environment. Environmental restoration activities at the SSFL include a thorough review of past programs and historical practices to identify, characterize, and correct all areas of potential concern. The key regulations governing the monitoring program are DOE Orders 5400.1 [DOE, 1990] and 5400.5 [DOE, 1993]. Additional guidance is drawn from California regulations and licenses, and appropriate standards.

The basic policy for control of radiological and chemical materials requires that adequate containment of such materials be provided through engineering controls, that facility effluent releases be controlled to federal and state standards, and that external radiation levels be reduced to as low as reasonably achievable (ALARA) through rigid operational controls. The environmental monitoring program provides a measure of the effectiveness of these operational procedures and of the engineering safeguards incorporated into facility designs. 


\subsubsection{Radiological Monitoring}

Monitoring the environment for potential impact from our past nuclear operations has been a primary focus of Rocketdyne and its predecessors.

In the mid 1950s, Atomics International, then a Division of North American Aviation, began initial plans for nuclear research at its facilities in the west San Fernando Valley. In 1956, prior to initial operations, it began an ambitious monitoring program to sample and monitor environmental levels of radioactivity in and around its facilities.

During the 45-year history of nuclear research and later environmental restoration, on-site and off-site environmental monitoring and media sampling have been extensive. In the early years, soil/vegetation sampling was conducted, on a monthly basis, as far west as the Moorpark freeway, as far North as the Ronald Reagan freeway, as far east as Reseda, and as far south as the Ventura freeway. Soil, vegetation, and water samples were also taken around the Canoga and De Soto facilities, and around the Chatsworth Resevoir. This extensive off-site sampling program was terminated in 1989 when all nuclear research and operations (except remediation) came to an end.

During the 1990s, extensive media sampling programs have been conducted on our northern neighbors (including the Brandies-Bardin Institute and the Santa Monica Mountains Conservancy), our neighbors to the south, the Rocketdyne Recreation Center in West Hills, various private homes in the Chatsworth and West Hills areas, and places as far afield as Wildwood Park and Tapia Park. These sampling projects have been in addition to the routine offsite monitoring of off-site radiation using thermoluminescent dosimeters (TLDs), routine groundwater monitoring of off-site wells, and routine sampling of surface water runoff from the site.

Figures 4-1a and 4-1b show sampling and monitoring locations for these two time periods.

Rocketdyne has not been alone in off-site sampling. Independent sampling has been performed by no less than twelve organizations. These are ...

- $\quad$ ANL-Argonne National Laboratory

- DHS/EMB-California Department of Health Services-Environmental Management Branch

- EPA/ORIA-US Environmental Protection Agency-Office of Radiation and Indoor Air

- DHS/RHB-California Department of Health Services-Radiologic Health Branch

- GRC-Groundwater Resources Consultants, Inc.

- Joel Cehn (consultant to the Brandies-Bardin Institute)

- LLNL-Lawrence Livermore National Laboratory 
- McLaren/Hart Environmental Engineering Corp.

- ORAU—Oak Ridge Associated Universities

- ORISE-Oak Ridge Institute of Science and Education

- Ogden Environmental and Energy Services

- $\quad$ RWQCB-Regional Water Quality Control Board

Table 4-1 shows a matrix of sampled media, sampling organization, and sampling time period for all historical off-site radiological monitoring.

The evidence from thousands of soil, vegetation, water, and air samples taken from over 200 off-site locations over the last 45 years by Rocketdyne and 12 other agencies and organizations demonstrates that ... no radioactive contamination has been detected off-site that could result in any exposure or any risk to our neighbors.

The EPA has stated that, "EPA is not aware of any current contamination from the SSFL that poses an unacceptable risk to the community."

The ATSDR has stated that, "There is currently no indication that off-site residential areas have been adversely impacted by materials from the site."

Our ongoing radiological environmental monitoring ensures that activities at the Santa Susana Field Laboratory, including cleanup, do not adversely affect either our employees or our neighbors. 


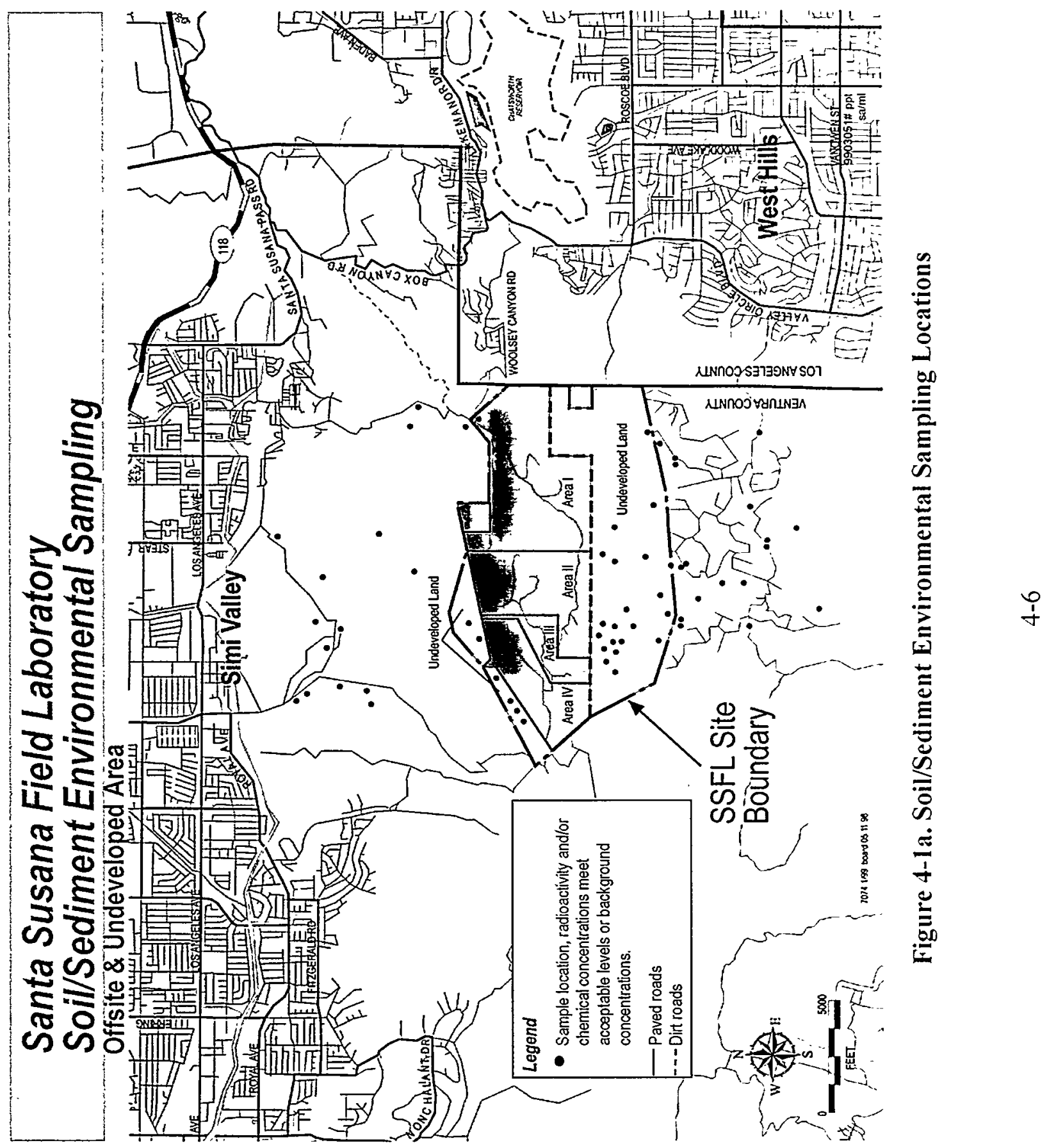

年 


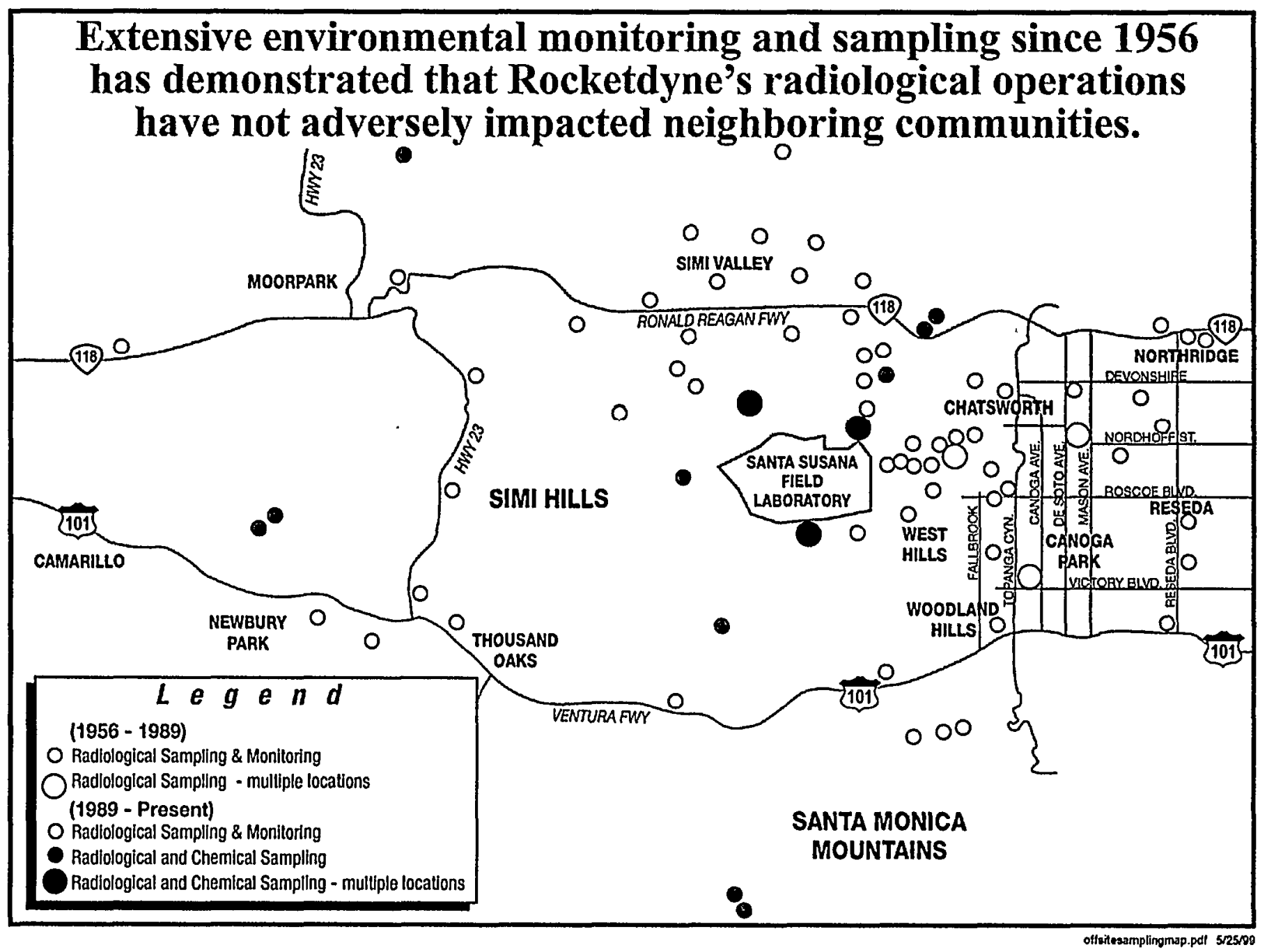

Figure 4-1b. Radiological Sampling and Monitoring Locations 
Table 4-1. Organizations Conducting Radiological Environmental Sampling

\begin{tabular}{|c|c|c|c|c|c|}
\hline \multicolumn{6}{|c|}{ Environmental Sampling for Radiation/Radioactivity Surrounding Santa Susana } \\
\hline \multirow{2}{*}{ Location } & \multicolumn{5}{|c|}{ Media Sampled (Date Range and Organization) } \\
\hline & Soil & Groundwater & Surface Water & Airborne Particulates & Radiation Exposure \\
\hline On-Site & $\begin{array}{c}\text { 1956-Present (Rocketdyne) } \\
\text { 1975, 81, } 84 \text { (ANL) } \\
\text { 1986-87 (ORAU) } \\
\text { 1992-Present (ORISE) } \\
\text { 1993 (RWQCB) } \\
\text { 1992-Present (DHS/RHB) } \\
\text { 1994-95 (DHS/EMB) }\end{array}$ & $\begin{array}{c}\text { 1960-86 (Rocketdyne) } \\
\text { 1984-Present (GRC) } \\
1998 \text { (EPA/ORIA) }\end{array}$ & $\begin{array}{c}\text { 1970-Present (Rocketdyne) } \\
\text { 1993-98 (RWQCB) }\end{array}$ & 1956-Present (Rocketdyne) & $\begin{array}{c}\text { 1971-Present (Rocketdyne) } \\
\text { 1975, 81, } 84 \text { (ANL) } \\
\text { 1981-Present (DHS/RHB) } \\
\text { 1986-87 (ORAU) } \\
\text { 1992-Present (ORISE) }\end{array}$ \\
\hline $\begin{array}{l}\text { North } \\
\text { Off-Site }\end{array}$ & $\begin{array}{c}\text { 1956-89 (Rocketdyne) } \\
\text { 1992-94 (McLaren/Hart) } \\
\text { 1992-94 (EPA/ORIA) } \\
1992-94 \text { (DHS/EMB) } \\
1991-97 \text { (Cehn) } \\
1995 \text { (Rocketdyne) } \\
1995 \text { (ORISE) }\end{array}$ & $\begin{array}{c}\text { 1984-Present (GRC) } \\
\text { 1991-96 (Cehn) } \\
1998 \text { (EPA/ORIA) }\end{array}$ & $\begin{array}{c}1992-94 \text { (McLaren/Hart) } \\
1992-94 \text { (EPA/ORIA) } \\
1992-94 \text { (DHS/EMB) } \\
1992-94 \text { (Cehn) }\end{array}$ & 1989 (DHS/RHB and LLNL) & $\begin{array}{c}\text { 1974-Present (Rocketdyne) } \\
\text { 1992-94 (EPA/ORIA) } \\
1995 \text { (ORISE) }\end{array}$ \\
\hline $\begin{array}{l}\text { East } \\
\text { Off-Site }\end{array}$ & $\begin{array}{c}1956-89 \text { (Rocketdyne) } \\
1986 \text { (ORAU) } \\
1994 \text { (Rocketdyne) } \\
1995 \text { (ORISE) } \\
1997 \text { (LLNL) }\end{array}$ & 1984-Present (GRC) & $1961-71$ (Rocketdyne) & 1959-Present (Rocketdyne) & $\begin{array}{c}\text { 1974-Present (Rocketdyne) } \\
1986 \text { (ORAU) } \\
1995 \text { (ORISE) }\end{array}$ \\
\hline $\begin{array}{l}\text { South } \\
\text { Off-Site }\end{array}$ & $\begin{array}{c}\text { 1956-89 (Rocketdyne) } \\
\text { 1992-94 (McLaren/Hart) } \\
\text { 1992-94 (EPA/ORIA) } \\
\text { 1992-94 (DHS/EMB) } \\
\text { 1992-94 (Cehn) } \\
1995 \text { (Rocketdyne) } \\
\text { 1998 (Ogden) }\end{array}$ & 1984-Present (GRC) & 1966-89 (Rocketdyne) & 1989 (DHS/RHB and LLNL) & 1974-Present (Rocketdyne) \\
\hline $\begin{array}{l}\text { West } \\
\text { Off-Site }\end{array}$ & $\begin{array}{c}\text { 1956-64 (Rocketdyne) } \\
\text { 1992-94 (McLaren/Hart) } \\
\text { 1992-94 (EPA/ORIA) } \\
\text { 1992-94 (DHS/EMB) } \\
\text { 1992-94 (Cehn) } \\
1995 \text { (Rocketdyne) }\end{array}$ & 1984-Present (GRC) & None & None & 1974-Present (Rocketdyne) \\
\hline
\end{tabular}




\subsubsection{Non-Radiological Monitoring}

Extensive monitoring programs for chemical contaminants in air, soil, surface water, and groundwater are in effect to assure that the existing environmental conditions do not pose a threat to the public welfare or environment. Soils contaminated by petroleum products are remediated whenever underground fuel tanks are removed. Extensive soil sampling is performed under the Resource Conservation and Recovery Act (RCRA) Facility Investigation and other site-specific remedial programs. Groundwater beneath Area IV is extensively monitored for chemical contaminants through sampling at 45 on-site and off-site wells. Groundwater analyses were conducted by Groundwater Resources Consultants, Inc. (GRC) following a DTSCapproved sampling and analysis plan and approved EPA analytical methods. Equipment installed in an interim groundwater remediation program in Area $\mathrm{N}$ removed solvents from contaminated groundwater at a throughput of about 93,000 gallons per month in 1999. This system returned remediated water to the surface water collection ponds.

All surface water discharges are monitored as specified in the existing National Pollutant Discharge Elimination System (NPDES) permit. The NPDES permit was renewed in 1998. In addition, all sources of emissions are monitored as required by the Ventura County Air Pollution Control District. Asbestos control is conducted under the requirements of Titles 29, 40, and 49 of the Code of Federal Regulations (CFR), in addition to any state or local regulations that apply to any specific asbestos abatement program.

In addition to this environmental monitoring and restoration program, current operational procedures reflect Rocketdyne's commitment to a clean and safe environment. For example, solvents and oils are collected and recycled, rather than being discarded. A comprehensive training and employee awareness program is in place. All employees working with hazardous materials are required to attend a course on hazardous materials waste management. Environmental bulletins are printed on the internal Rocketdyne website to promote environmental awareness among all employees.

\subsection{ENVIRONMENTAL TRAINING}

Rocketdyne conducts training and development programs as an investment in human resources to meet both organizational and individual goals. These programs are aimed toward improving employee performance, assuring employee proficiency, preventing obsolescence in employee capability, and preparing employees for changing technology requirements and for possible advancement.

The People Organization is responsible for the development and administration of formal training and development programs. Process managers are responsible for individual employee development through formal training, work assignments, coaching, counseling, and performance evaluation. Process managers and employees are jointly responsible for defining and implementing individual training development goals and plans, including on-the-job training.

The Rocketdyne Training and Development Department currently maintains a listing of approximately 700 courses available for Rocketdyne personnel. Of these, approximately 102 relate to environment, health, and safety, with approximately 10 relating to environmental protection, 10 to radiation safety and remediation, and 82 to health and safety. Specialized 
training programs on new technological developments and changes in regulations are provided, as needed, to ensure effective environmental protection and worker health and safety. Also, informal discussions about waste minimization and management occur at hazardous waste coordinator's meetings. Several courses are available as computer-based training. Additional offsite courses are also encouraged.

\subsection{WASTE MINIMIZATION AND POLLUTION PREVENTION}

\subsubsection{Program Planning and Development}

A Waste Minimization and Pollution Prevention Awareness Plan developed in accordance with DOE Order 5400.1 (DOE, 1990) has been in place since December 1993. This plan [Atkinson, 1996] serves as a guidance document for all waste generators at the ETEC. The plan emphasizes management's proactive policy of waste minimization and pollution prevention, and outlines goals, processes, and waste minimization techniques to be considered for all waste streams generated at the former ETEC. The plan requires that waste minimization opportunities for all major restoration projects be performed and all cost-effective waste reduction options be implemented.

The majority of waste currently generated at the former ETEC is attributable to environmental management activities related to environmental restoration of surplus facilities and clean up of contaminated sites from previous programs. The key hazardous components of waste generated at ETEC are:

- Low-level radioactive waste (LLW), mixed, hazardous, and non-hazardous wastes from $\mathrm{D} \& \mathrm{D}$ operations.

- Sodium and NaK-contaminated components from D\&D operations at the former sodium facilities.

- $\quad$ Oils from ongoing remediation activities.

- Solvents and paints.

- In general, the measures used to promote waste minimization at ETEC are:

- Using comprehensive segregation and screening procedures to minimize mixed wastes by separating LLW and hazardous wastes.

- Using survey and decontamination processes to release concrete and steel for potential recycling/reuse.

- Removing bulk sodium from facility drain tanks for recycling/reuse.

- Converting residual sodium in piping and components to high-grade sodium hydroxide for commercial use.

- Reusing containers of radioactive LLW for storage. 
- Linking a chemical/material exchange system with the purchasing system to reduce purchases of hazardous materials.

- Reducing non-hazardous waste disposal through process changes and recycling.

- Using/operating improved air filtration technology in decontamination facility to minimize generation of filter media wastes.

Waste minimization is accomplished by evaluating the waste generating processes, identifying waste minimization options, and finally conducting technical and economic evaluations to determine the best approach.

\subsubsection{Training and Awareness Programs}

The ETEC Waste Minimization and Pollution Prevention Awareness Program includes (1) orientation programs and refreshers, (2) specialized training, and (3) incentive awards and recognition. New ETEC employees attend an orientation program that describes waste generation, treatment, disposal, minimization, and pollution prevention. Orientation presentations are designed to increase pollution prevention and waste minimization awareness and to motivate employees.

Employees are reminded about pollution prevention and waste minimization awareness. Posters are placed in work areas to notify employees about environmental issues or practices. Memoranda are circulated about changes in waste management policy, Rocketdyne policies or procedures, and technical data relevant to an employee's job assignment. Presentations using visual aids are provided, as needed, to review major changes in environmental issues.

\subsubsection{Waste Minimization and Pollution Prevention Activities}

The following are some significant activities related to waste minimization and pollution prevention.

- Oils used in motor vehicles and compressors are shipped to vendors who recycle them.

- Use comprehensive segregation and screening procedure of radioactive (RA) materials resulting in the salvage of usable nonradioactive scrap metal.

- A chemical/material exchange system is currently linked to the purchasing system and prevents the unnecessary purchase of hazardous materials.

- Hazardous waste containers in acceptable condition are reused to the maximum extent possible.

- Empty product drums are returned to the vendor for reuse when practical.

- Approximately $80 \%$ of the white paper and aluminum cans are recycled as a result of increased environmental awareness. During CY99, 3.9 metric tons of white paper and 2.4 metric tons of aluminum cans were recycled. 
- Use of a compactor to reduce the volume of soft low-level RA waste with 5 to 15 compaction ratios (soft trash limited to two boxes during 1999).

- Size reduction and repackaging achieved significant RA waste reduction. These activities resulted in a waste reduction of approximately $1,100 \mathrm{ft}^{3}$ of LLW during 1999.

- Operation of a Torit self-cleaning filter unit in a radiological decontamination facility eliminated waste consisting of about 20 used prefilters that would have been generated using a conventional unit in CY 1999.

- Approximately $10,000 \mathrm{lb}$ of residual sodium in tanks and piping systems were converted into commercial-grade sodium hydroxide using a water vapor nitrogen (WVN) process. This resulted in avoiding generation of approximately 2,200 gallons of hazardous waste during 1999.

- Approximately 4,700 lb of bulk sodium was transferred off-site for reuse

- Approximately 34 metric tons of clean recyclable stainless steel and 420 metric tons of carbon steel resulted from divestment activities.

- Implementation of the waste minimization assessment for the D\&D of the Hot Lab (Bldg 4020) resulted in the reduction and release for reuse (by decontamination and survey) of 2,380 metric tons of concrete during 1999.

\subsubsection{Tracking and Reporting System}

Various categories of materials from procurement to waste disposal are tracked. Radioactive and mixed wastes are characterized sufficiently (for safe storage) by the generator, transferred to the RMHF, and logged and temporarily stored at the RMHF. Documents that accompany the wastes are verified for accuracy and completeness and filed at the RMHF. Hazardous waste tracking and verification procedures (from generator to final off-site disposal) are followed up by the SHEA department. Rocketdyne is responsible for all nonhazardous and sanitary waste operations at the SSFL.

Relevant reports include:

- EPA's Biennial Hazardous Waste Report

- DOE's Annual Waste Generation and Pollution Prevention Progress Report

- DOE's Affirmative Procurement Report

- "Source Reduction Evaluation Review and Plan" and "Hazardous Waste Management Performance Report," both of which are required by the "Source Reduction and Hazardous Waste Management Review Act (SB14)" 


\section{ENVIRONMENTAL RADIOLOGICAL MONITORING}

Environmental radiological monitoring program at SSFL began before the first radiological facilities were established in 1956 . The program has continued with modifications to suit the changing operations. The selection of monitoring locations was based on several sitespecific criteria such as topography, meteorology, hydrology, and the locations of the nuclear facilities. The prevailing wind direction for the SSFL site is generally from the north and northwest, with some seasonal diurnal shifting to the southeast quadrant. Most rainfall runoff at the SSFL site flows through several natural watercourses and drainage channels and is collected in two large-capacity retention ponds. This water may be discharged off-site into Bell Creek to the south, or it may be reused for industrial purposes. Surface water from Area IV also flows to the northwest and is monitored through five NPDES sampling locations.

Gross alpha and gross beta measurements of ventilation exhaust and ambient air samples are used for screening purposes to quickly identify any unusual release and to permit a long-term historical record of radioactivity in the environment. These samples are also analyzed annually for specific radionuclides. Detailed analyses of these samples permit more accurate estimates of the potential off-site dose from air pathway.

Gross alpha and gross beta analyses performed on surface water and groundwater permit direct comparison with the screening limits established by the EPA for suppliers of drinking water. For groundwater, samples are also analyzed for gamma emitters and tritium, and isotopic uranium and thorium analysis is performed if gross alpha activity exceeds the drinking water limit. For surface water, $\mathrm{Sr}-90$ and tritium analyses are also performed.

Direct radiation is monitored by the thermoluminescent dosimeters (TLD) mounted on site boundary and throughout the site. To accurately measure low-level ambient radiation, "sapphire" TLDs, which are very sensitive to low-level radiation, were used. These TLDs were complemented by TLDs installed by the State of California Department of Health Services Radiologic Health Branch for independent surveillance.

\subsection{EFFLUENT MONITORING}

The RMHF and Buildings 4024 and 4059 have continuous effluent monitoring capability. In 1999, effluent was only monitored for the RMHF and Building 4024 because no radiological work in Building 4059 required the use of portable filtered exhaust system during the year. Airborne releases from the RMHF are shown in Table 5-1, Sheet 1. All the air releases are below the Derived Concentration Guides (DCGs) of DOE Order 5400.5 [DOE, 1993]. No man-made radionuclides were released to the atmosphere from Building 4024 (Table 5-1, Sheet 2).

Workplace ventilation is provided in all areas where unencapsulated or unpackaged radioactive material is handled, such as in the 4024 Hot Lab satellite area and in the decontamination and packaging rooms at RMHF (where equipment is decontaminated and radioactive waste is repackaged). This assures protection of the workers from inhalation of airborne radioactive material and prevents the spread of radioactive contamination into adjacent clean areas. The ventilation exhaust is passed through HEPA filters before being discharged to 
Table 5-1. Atmospheric Effluents to Uncontrolled Areas

(Sheet 1 of 2)

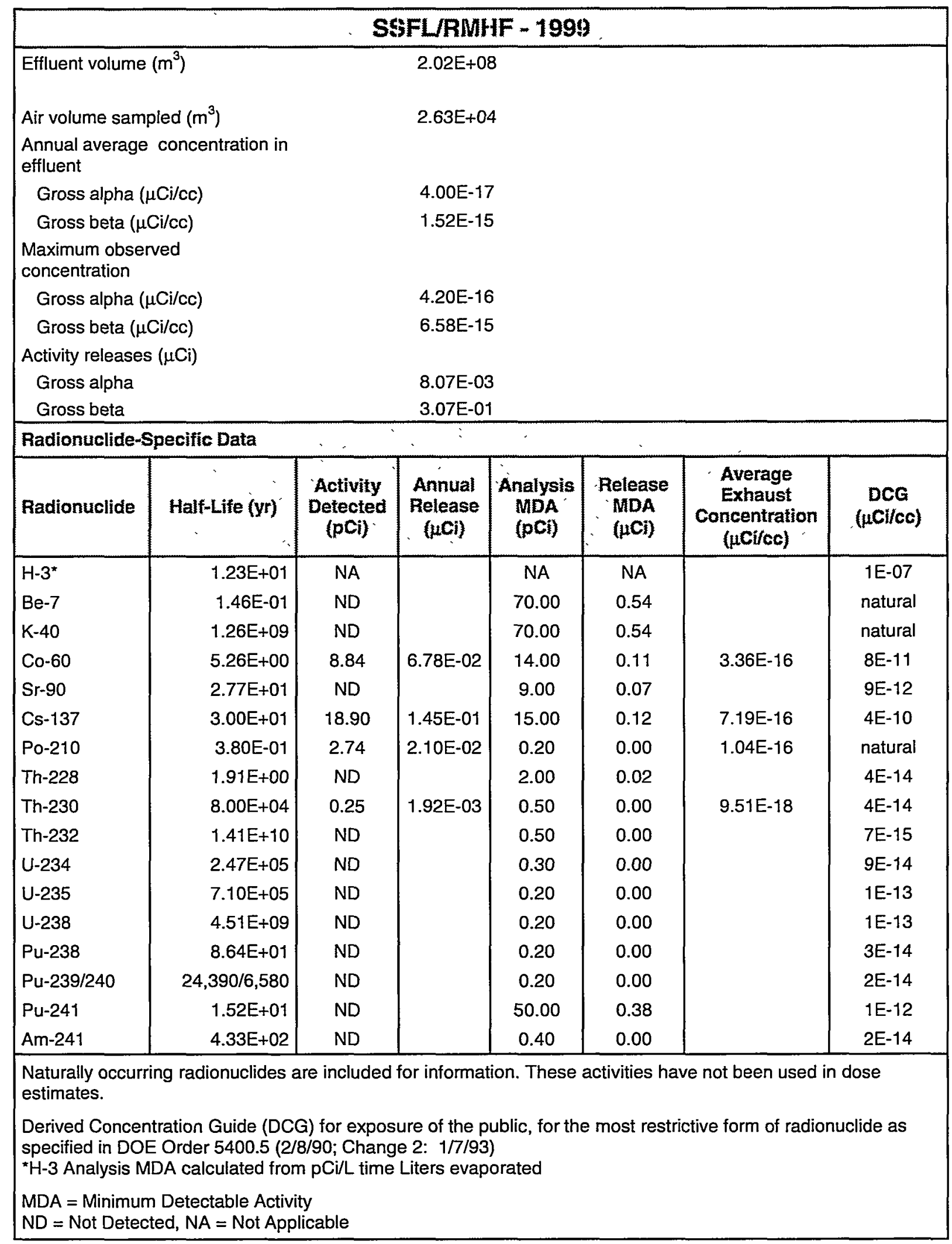


Table 5-1. Atmospheric Effluents to Uncontrolled Areas

(Sheet 2 of 2)

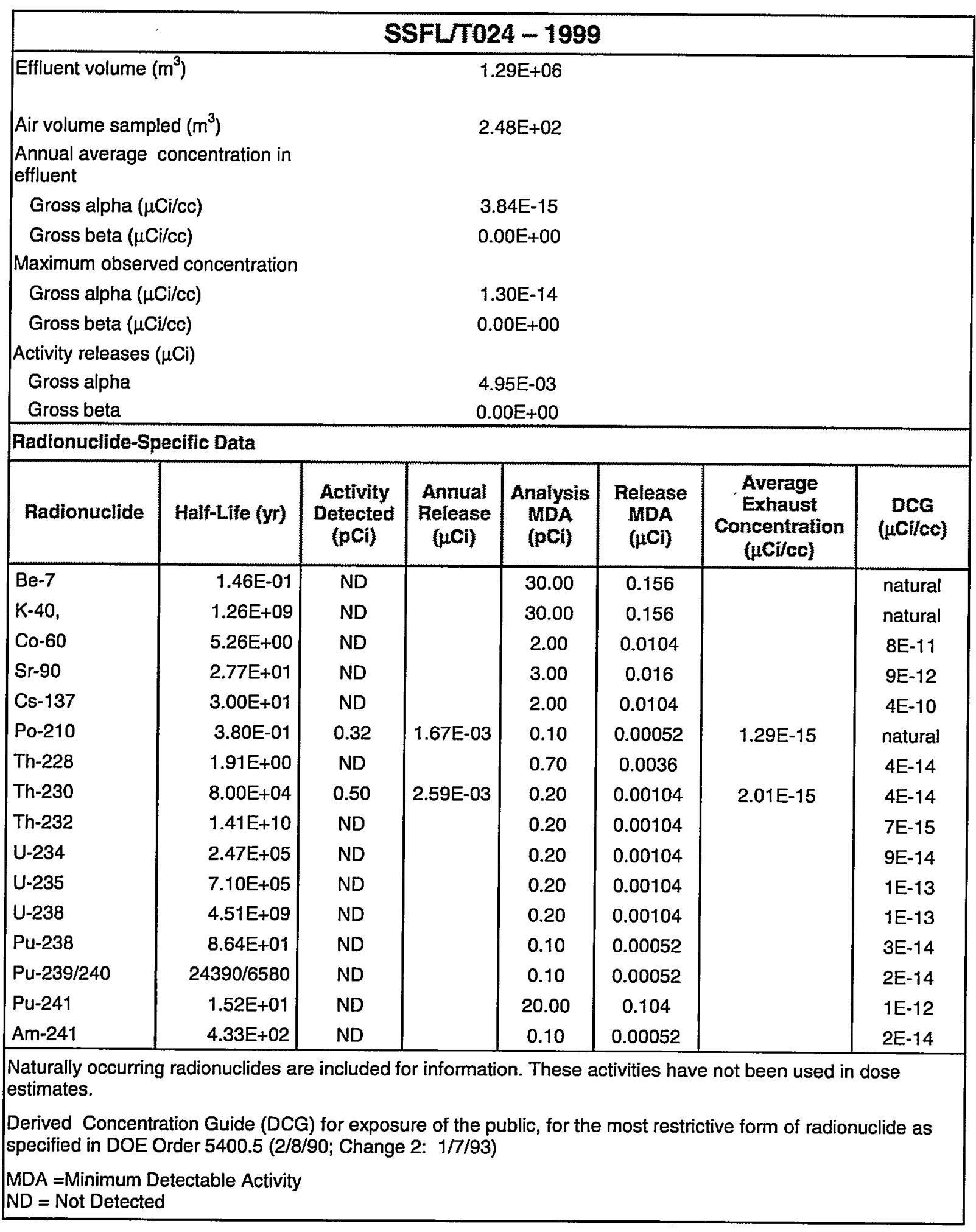


the atmosphere to prevent the release of airborne radioactivity. The filtered air generally contains lower levels of long-lived radioactivity than does ambient air from naturally occurring radionuclides in the atmosphere. Essentially all short-lived radioactivity in the air is caused by natural Be-7 and the naturally present radon progeny, which dominate the airborne activity.

The ventilation exhaust is sampled to measure the effluent radioactivity. Data from this sampling is used to demonstrate compliance with State DHS/RHB, DOE, and EPA (NESHAPs) standards. The U.S. EPA regulates airborne releases of radioactivity from DOE facilities under 40 CFR 61, Subpart H.

The potential release of effluent radioactivity to uncontrolled areas is by way of filtered discharge of ventilation exhaust from the RMHF, 4024 tent, and occasional diffuse area sources. No contaminated liquids are discharged to uncontrolled areas. The only diffuse area source considered significant for 1999 was a temporarily dry runoff collection sump for the RMHF.

The level of radioactivity contained in all atmospheric effluents is reduced to the lowest practical value by passing the effluents through certified HEPA filters. The effluents are sampled for particulate radioactive materials by means of continuously operating stack exhaust samplers at the point of release. In addition, the stack monitor installed at the RMHF provides automatic alarm capability in the event of the release of particulate activity. The HEPA filters used for filtering atmospheric effluents are at least $99.97 \%$ efficient for particles $0.3 \mu \mathrm{m}$ in diameter.

The average concentration and total radioactivity, as gross alpha and gross beta activity, in atmospheric effluents to uncontrolled areas from the RMHF and 4024 are shown in Table 5-1. The total shows that no significant quantities of radioactivity were released in 1999 . To permit identification of any unusual release, the gross alpha and gross beta counts are done shortly after the weekly stack sample is collected. These results include the naturally occurring radionuclides present in air, Be-7, K-40, Po-210, and Th-230. Detailed analyses are performed on the entire sets of filter samples at the end of the year to provide the greatest analytical sensitivity.

The isotopic composition of the radioactivity deposited on the nuclear facility exhaust air sampling filters, composited for the year, is also presented in Table 5-1. Gamma-emitting radionuclides were measured by using a high-resolution gamma spectrometer. All others were measured by using specific chemical separations followed by alpha or beta counting and electrolytic enrichment of tritium followed by liquid scintillation counting. Radionuclides that were reported as less than the method detection level are shown as "not detected" (ND). The Po-210 collected on the filters is due to naturally occurring elements from the U-238 decay chain in the environment. The $\mathrm{K}-40$ is due to the presence of this radionuclide in natural potassium of the airborne dust in the ambient air. Be-7 had decayed below the detection level by the time of the analysis. Materials used in operations conducted at the SSFL sites are responsible for the fission/activation product radioactivity.

For each radionuclide detected, the laboratory calculates minimum detectable activity (MDA). This is the lowest activity that would be identified as "detected" with $95 \%$ confidence. For the purpose of comparing effluent releases, the laboratory MDA for the composited filters was converted to an equivalent annual release and is shown in the table as the release MDA. 
The concentrations in the effluent at the exhaust stack for each facility are compared with appropriate limits for exposure of the public. The isotopic limits for DOE facilities are DCGs for exposure of the public for the most restrictive form of the radionuclide as specified in DOE Order 5400.5. These values refer to the permissible concentrations allowed by the State of California and the DOE for continuous exposure of the public. Note that in all cases for the exhaust air, the observed concentrations are far below the DCG (as shown in Table 5-2). Furthermore, dilution and dispersion occur before the material reaches an unrestricted area, which further reduce the concentration in the public area.

The potential downwind radiation exposures due to the atmospheric emissions during 1999 from the RMHF exhaust stack have been calculated using the CAP88-PC computer code. Sitespecific input data such as wind speed, directional frequency and stability (developed by the National Regulatory Commission [NRC] and ANL), and stack height and exhaust air velocity were used to perform the dose assessment.

The highest potential radiation exposure doses at the site boundary and the nearest residential area were estimated using the CAP88-PC computer code, and the results are presented in Table 5-3. Although the new SSFL site boundary is 300 meters from the RMHF, the maximum dose occurs at distance of 325 meters. Therefore, the boundary dose was calculated at this distance.

The airborne dose calculations were performed to demonstrate compliance with the NESHAPs standard. At the location of the hypothetical Maximally Exposed Individual (MEI), the effective dose equivalent from DOE facility exhaust during 1999 (RMHF) was $2.2 \times 10^{-7}$ mrem $\left(2.2 \times 10^{-9} \mathrm{mSv}\right)$ per year. The EPA limit for a DOE site is $10 \mathrm{mrem} / \mathrm{yr}$, as specified in 40 CFR 61, Subpart H. Potential releases from the RMHF are so low that, even assuming absence of HEPA filters, estimated doses would be below the level requiring continuous monitoring. However, continuous monitoring is still being performed as a best management practice.

In addition to the above point source, analyses were performed to determine the maximum estimated individual dose due to potential releases from "area" source. The only area source considered for 1999 is the RMHF pond (Sump 614). The pond was dry for 50 days during 1999 and was subject to possible resuspension of sediment by the wind. The RMHF North Slope has been considered to be an occasional source in prior years but is now fully covered by native vegetation, and, thus, no wind borne resuspension of radioactively contaminated soil can occur.

The estimated dose to the hypothetical MEI due to potential releases from the area source is $6.6 \times 10^{-7} \mathrm{mrem}\left(6.6 \times 10^{-9} \mathrm{mSv}\right)$ for 1999 . Since releases from the area source were too small to permit accurate measurements, potential releases were estimated using the same method used in the RESRAD computer program [Yu, 1993], for calculation of airborne radioactivity caused by resuspension of soil by the wind. These estimated releases were used as input in the CAP88PC program to perform the area source dose assessments. Releases from these sources have not been detectable by on-site continuous ambient air sampling. 
Table 5-2. Filtered Exhaust and Ambient Air Radioactivity Concentrations-1999

\begin{tabular}{|c|c|c|c|c|c|c|c|c|c|c|}
\hline \multirow{3}{*}{ Radionuclide } & \multicolumn{10}{|c|}{ Activity Concentration (microcuries per cubic centimeter, $\mu \mathrm{Ci} / \mathrm{cc}$ ) } \\
\hline & \multirow{2}{*}{$\begin{array}{c}\text { Derived } \\
\text { Conc. Guide }\end{array}$} & \multicolumn{2}{|c|}{ Exhaust } & \multicolumn{5}{|c|}{ Ambient } & \multicolumn{2}{|c|}{ Average } \\
\hline & & AMHF & T024 & RMHF & RMHF Pond & RIHL & T10o & T886 & Exhaust & Ambil \\
\hline $\mathrm{H}-3$ & $1 \mathrm{E}-07$ & & & & & & & & & \\
\hline $\mathrm{Be}-7$ & natural & & & $1.7 E-14$ & & & & & & 1.7E- \\
\hline $\mathrm{K}-40$ & natural & & & & $1.3 E-14$ & & & & & 1.3E- \\
\hline Co-60 & $8 E-11$ & $3.4 \mathrm{E}-16$ & & & & & & & $3.4 \mathrm{E}-16$ & \\
\hline Sr-90 & $9 E-12$ & & & & & & & & & \\
\hline Cs-137 & $4 \mathrm{E}-10$ & $7.2 \mathrm{E}-16$ & & & & & & & $7.2 \mathrm{E}-16$ & \\
\hline Po-210 & natural & $1.0 \mathrm{E}-16$ & 1.3E-15 & $3.3 \mathrm{E}-15$ & 5.3E-15 & 5.3E-15 & $4.2 E-15$ & $4.2 E-15$ & $7.0 \mathrm{E}-16$ & $4.5 \mathrm{E}$ \\
\hline Th-228 & $4 \mathrm{E}-14$ & & & & & & & & & \\
\hline Th-230 & $4 \mathrm{E}-14$ & & & & & & $1.4 \mathrm{E}-16$ & & & $1.4 \mathrm{E}-$ \\
\hline Th-232 & $7 E-15$ & & & & & & & & & \\
\hline U-234 & $9 \mathrm{E}-14$ & & & & & & & & & \\
\hline U-235 & $1 \mathrm{E}-13$ & & & & & & & & & \\
\hline $\mathrm{U}-238$ & $1 E-13$ & & & & & & & & & \\
\hline Pu-238 & $3 E-14$ & & & & & & & & & \\
\hline Pu-239/240 & $2 E-14$ & & & & $2.9 \mathrm{E}-16$ & & & & & $2.9 \mathrm{E}-$ \\
\hline Pu-241 & $1 E-12$ & & & & & & & & & \\
\hline Am-241 & $2 E-14$ & & & & & & & & & \\
\hline Gross Alpha & None & 4.0E-17 & $3.8 E-15$ & $3.0 \mathrm{E}-15$ & $2.1 E-15$ & $2.5 \mathrm{E}-15$ & $1.9 \mathrm{E}-15$ & $2.3 E-15$ & $1.9 \mathrm{E}-15$ & $2.4 \mathrm{E}-$ \\
\hline Gross Beta & None & $1.5 \mathrm{E}-15$ & $0.0 \mathrm{E}+00$ & $1.9 \mathrm{E}-14$ & $1.7 \mathrm{E}-14$ & $1.9 \mathrm{E}-14$ & 1.7E-14 & $1.4 E-14$ & $7.6 \mathrm{E}-16$ & $1.7 \mathrm{E}$ \\
\hline
\end{tabular}


- Building 4024 was used as a staging and decontamination area for the Hot Lab concrete blocks extracted from the building during remediation activities. A portable tent was set up with a portable HEPA ventilation system to provide negative pressure inside the tent during block decontamination. This HEPA unit exhausted to the outside environment and was monitored in a manner similar to the monitoring done at facility stacks. Detailed analysis of the filters indicated no man-made radioisotopes. Therefore, the resulting doses at the site boundary and the nearest resident were zero.

Airborne releases from Building 4024 are detailed in Table 5-1, Sheet 2. Only natural isotopes, Th-230 and Po-210, were present. Weekly gross alpha and beta analyses of the filters showed that the exhaust air was well below the DCGs of DOE Order 5400.5.

Table 5-3. Radiation Exposure Dose due to Atmospheric Effluents-1999

\begin{tabular}{|c|c|c|c|c|}
\hline \multirow{2}{*}{ Facility } & \multicolumn{2}{|c|}{$\begin{array}{c}\text { Distance }(\mathrm{m}) \text { and } \\
\text { Direction to }\end{array}$} & \multicolumn{2}{c|}{$\begin{array}{c}\text { Downwind Exposure Dose } \\
\text { (mrem/yr) }\end{array}$} \\
\cline { 2 - 5 } & Boundary & Residence & Boundary & Residence \\
\hline RMHF & $325 \mathrm{NW}$ & $2,867 \mathrm{NW}$ & $2.1 \times 10^{-6}$ & $2.2 \times 10^{-7}$ \\
\hline
\end{tabular}

\subsection{ENVIRONMENTAL SAMPLING}

\subsubsection{Ambient Air}

Ambient air sampling is performed continuously at SSFL with air samplers operating on 7-day sampling cycles. The sampling locations are shown in Figure 5-1 and listed in Table 5-4. Airborne particulate radioactivity is collected on glass fiber (Type A/E) filters that are changed weekly at the end of each sampling period. The samples are counted for gross alpha and beta radiation following a minimum 120-hour decay period to allow for decay of short-lived radon and thoron daughters. The volume of a typical weekly ambient air sample is approximately $50.4 \mathrm{~m}^{3}$.

Weekly ambient air samples are counted for gross alpha and beta radiation with a lowbackground, thin-window, gas-flow proportional-counting system. The system is capable of simultaneously counting both alpha and beta radiation. The sample-detector configuration provides a nearly hemispherical $(2 \pi)$ geometry. The thin-window detector is continually purged with argon/methane counting gas. A preset time mode of operation is used to count all samples.

Counting system efficiencies are determined routinely with Tc-99 and Th-230 standard sources. The activities of the standard sources are traceable to the National Institute of Standards and Technology (NIST).

Filter samples for each ambient air sampling location are composited annually and analyzed for isotopic-specific activity. The results of the sample analyses are shown in Table 5-2. 


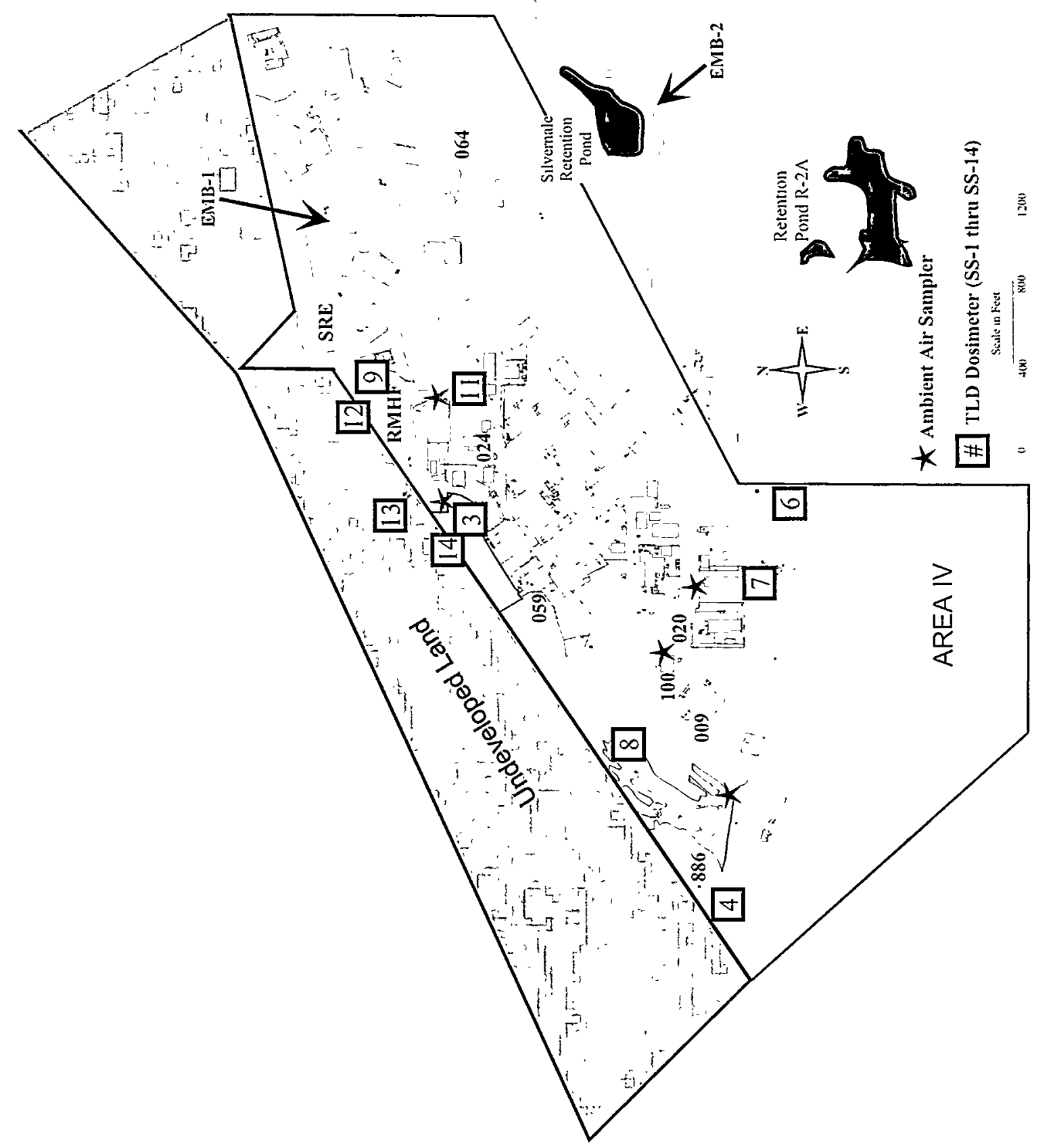

Figure 5-1. Map of Santa Susana Field Laboratory Area IV Sampling Stations 
Table 5-4. Sampling Location Description

\begin{tabular}{|c|c|c|c|c|}
\hline Station & \multicolumn{3}{|c|}{ Location } & $\begin{array}{l}\text { Sampling } \\
\text { Frequency }\end{array}$ \\
\hline \multicolumn{4}{|c|}{ Ambient Air Sampler Locations } & \\
\hline A-2 & \multicolumn{3}{|c|}{ SSFL Site, 4020, northeast of site } & $(W)$ \\
\hline A-3 & \multicolumn{3}{|c|}{ SSFL Site, 4034 , at main gate } & $(W)$ \\
\hline A-4 & \multicolumn{3}{|c|}{ SSFL Site, 4886, Former Sodium Disposal Facility } & $(W)$ \\
\hline$A-5$ & \multicolumn{3}{|c|}{ SSFL Site, RMHF Pond, north side } & $(\mathrm{W})$ \\
\hline A-6 & \multicolumn{3}{|c|}{ SSFL Site, 4100 , east side } & $(W)$ \\
\hline \multicolumn{5}{|c|}{ On-Site - SSFL - Ambient Radiation Dosimeter Locations } \\
\hline SS-3 (CA) & \multicolumn{3}{|c|}{ SSFL Site, Electric Substation 719 on boundary fence } & (Q) \\
\hline SS-4 (CA) & \multicolumn{3}{|c|}{ SSFL Site, west boundary on $\mathrm{H}$ Street } & (Q) \\
\hline SS-6 (CA) & \multicolumn{3}{|c|}{ SSFL Site, northeast corner of 4353} & $(Q)$ \\
\hline SS-7 (CA) & \multicolumn{3}{|c|}{ SSFL Site, 4363 , north side } & (Q) \\
\hline SS-8 (CA) & \multicolumn{3}{|c|}{ SSFL Site, Former Sodium Disposal Facility north boundary } & (Q) \\
\hline SS-9 (CA) & \multicolumn{3}{|c|}{ SSFL Site, RMHF northeast boundary at 4133} & (Q) \\
\hline SS-11 (CA) & \multicolumn{3}{|c|}{ SSFL Site, 4036, east side } & (Q) \\
\hline SS-12(CA) & \multicolumn{3}{|c|}{ SSFL Site, RMHF northwest property line boundary } & (Q) \\
\hline SS-13 (CA) & \multicolumn{3}{|c|}{ SSFL Site, RMHF northwest property line boundary } & (Q) \\
\hline SS-14 (CA) & \multicolumn{3}{|c|}{ SSFL Site, RMHF northwest property line boundary } & (Q) \\
\hline EMB-1 (CA) & \multicolumn{3}{|c|}{ SSFL Site, SRE area north of 4003} & (Q) \\
\hline EMB-2 (CA) & \multicolumn{3}{|c|}{ SSFL Site, south of Silvernale retention pond, off Test Area Road } & (Q) \\
\hline \multicolumn{4}{|c|}{ Off-Site Ambient Radiation Dosimeter Locations } & \\
\hline OS-1 (CA) & \multicolumn{3}{|c|}{ Off-site, Chatsworth } & (Q) \\
\hline OS-5 & \multicolumn{3}{|c|}{ Off-site, Thousand Oaks } & $(\mathrm{Q})$ \\
\hline BKG-11 & \multicolumn{3}{|c|}{ Background Location, West Hills } & (Q) \\
\hline BKG-12 & \multicolumn{3}{|c|}{ Background Location, Somis } & (Q) \\
\hline BKG-13 & \multicolumn{3}{|c|}{ Background Location, Hollywood } & (Q) \\
\hline BKG-15 & \multicolumn{3}{|c|}{ Background Location, Simi Valley (west) } & (Q) \\
\hline BKG-18 & \multicolumn{3}{|c|}{ Background Location, Calabasas } & $(Q)$ \\
\hline BKG-19 & \multicolumn{3}{|c|}{ Background Location, Burbank } & (Q) \\
\hline BKG-22 & Background Locat & & & (Q) \\
\hline Codes & & Locatic & & \\
\hline Air & ler Station & SS & SSFL & \\
\hline w & ample & os & Off-site & \\
\hline Q & Sample & BKG & Background & \\
\hline $\mathrm{CA}$ & ffirmatory Location & EMB & Environmental & ement Branch \\
\hline
\end{tabular}


with the effluent results for comparison. Like effluent air samples, the ambient air samples have radionuclide concentrations far below the DCG values. The variability in the measurements was dominated by weather effects and by analytical and background variations.

It should be emphasized that these measurements determine only the long-lived particulate radioactivity in the air and, therefore, do not show radon (Rn-222) and most of its progeny. Polonium-210 is a long-lived progeny and is detected by these analyses. It is assumed to be in equilibrium with its parent, $\mathrm{Pb}-210$, whose relatively long half-life (22.3 years) provides an essentially constant level of Po-210 in the samples. Because of these effects, the ambient air (the air that is being breathed) is actually about four times as radioactive as implied in this table. Since most short-lived particulate radioactivity is removed from the exhaust air by the HEPA filters, these effects are not significant in the filtered effluent.

Because the gross alpha and gross beta activity are counted shortly after collection, most natural Be-7 is detected, which elevates the gross beta activity. Be-7 decays by electron-capture and emits a gamma ray in $10 \%$ of the decays; this gamma ray is detected as weak beta activity. The naturally occurring radionuclides, Po-210, Ra-226, Ra-228, also contribute to the activity detected on the air filter samples. A more complete list of the results from the gross alpha and gross beta counting of the ambient air samples is shown in Table 5-5.

Guide values for SSFL site ambient air are based on the effluent concentration limits in DOE Order 5400.5 [DOE, 1993]. The conservative guide value for alpha activity is $2 \times 10^{-14}$ $\mu \mathrm{Ci} / \mathrm{mL}$. The appropriate value for beta activity is $9 \times 10^{-12} \mu \mathrm{Ci} / \mathrm{mL}$ (Sr-90) due to the presence of Sr-90 in fission product contamination from previous work with irradiated nuclear fuel at the SSFL.

The activity detected in ambient air is attributed to naturally occurring radioactive materials. Radionuclides detected by gross alpha and beta analysis of air samples collected during 1999 include K-40 plus several naturally occurring radionuclides from the uranium and thorium series (Table 5-2). 
Table 5-5. Ambient Air Radioactivity Data-1999

\begin{tabular}{|c|c|c|c|c|c|}
\hline \multirow[b]{2}{*}{ Area } & \multirow[b]{2}{*}{ Activity } & \multirow[b]{2}{*}{$\begin{array}{l}\text { Number } \\
\text { of } \\
\text { Samples }\end{array}$} & \multicolumn{3}{|c|}{ Gross Radioactivity Concentrations $(\mu \mathrm{Ci} / \mathrm{mL})$} \\
\hline & & & $\begin{array}{c}\text { Annual Average } \\
\text { Value and } \\
\text { Dispersion }\end{array}$ & $\begin{array}{l}\text { Maximum Value } \\
\text { and Date } \\
\text { Observed }\end{array}$ & $\begin{array}{l}\text { Average } \\
\text { Percent of } \\
\text { Guide }^{\mathrm{b}}\end{array}$ \\
\hline SSFL Area IV & Alpha & 51 & $5.50 \mathrm{E}-16$ & $5.50 \mathrm{E}-15(7 / 21)$ & 2.8 \\
\hline T100 & Beta & & $1.90 \mathrm{E}-14$ & $7.20 E-14(9 / 22)$ & 0.2 \\
\hline SSFL Area IV & Alpha & 51 & $8.60 E-16$ & $7.70 \mathrm{E}-15(11 / 17)$ & 4.3 \\
\hline Hot Lab & Beta & & $2.10 E-14$ & $6.40 \mathrm{E}-14(9 / 22)$ & 0.2 \\
\hline SSFL Area IV & Alpha & 51 & $3.00 E-16$ & $5.10 \mathrm{E}-15(10 / 22)$ & 1.5 \\
\hline RMHF & Beta & & $1.40 E-14$ & $5.30 \mathrm{E}-14(11 / 13)$ & 0.2 \\
\hline SSFL Area IV & Alpha & 51 & $3.50 E-16$ & $8.60 \mathrm{E}-15(7 / 7)$ & 1.8 \\
\hline 4886 & Beta & & $1.90 E-14$ & $1.10 \mathrm{E}-13(7 / 7)$ & 0.2 \\
\hline SSFL Area IV & Alpha & 51 & $7.10 E-16$ & $5.50 \mathrm{E}-15(9 / 29)$ & 3.6 \\
\hline RMHF Pond & Beta & & $2.30 E-14$ & $1.20 \mathrm{E}-13(10 / 6)$ & 0.3 \\
\hline
\end{tabular}

\subsubsection{Groundwater}

Forty-five wells in and around Area IV are used to monitor the condition of the groundwater in the unconsolidated surface alluvium and the underlying Chatsworth formation. The locations of these wells are shown in Figure 6-2. The purpose of these wells is to monitor concentrations of chemicals and/or radioactivity released by DOE operations. Water samples from these wells are periodically analyzed for radioactivity. Forty-three water samples from 26 of these wells were collected and analyzed in 1999, and the summary results are shown in Table 5-6.

The drinking water standards have been assigned to groundwater by the State of California as a water-quality goal, and are applied here. Numerical limits for radionuclides not specifically listed by the State for drinking water were derived from the EPA generic dose limit of $4 \mathrm{mrem} / \mathrm{yr}$. Except for five instances of gross alpha (16.1 to $26.9 \mathrm{pCi} / \mathrm{L}$ ) and one instance of gross beta $(58 \mathrm{pCi} / \mathrm{L})$, the monitored groundwater satisfies these goals. The high gross alpha concentrations are due to the presence of higher levels of naturally occurring uranium. Gamma spectrometry analysis did not detect any man-made beta and gamma emitters.

Groundwater is extracted from a French drain around a basement area of Building 4059 to prevent any inflow or outflow of groundwater into a part of the building currently undergoing remediation. During 1999, this water was released to the surface drainage water collection system. Samples were analyzed by gamma spectrometry. The results of these analyses showed no detectable activities for man-made gamma emitting radionuclides. 
Table 5-6 Radioactivity in Groundwater at SSFL-1999

\begin{tabular}{|c|c|c|c|c|c|c|c|c|c|c|}
\hline & \multicolumn{10}{|c|}{ Activity (pcin) } \\
\hline & $\mathrm{H}-3$ & Cs-137 & Th-228 & Th-230 & Th-232 & U-234 & U-235 & U-238 & $\begin{array}{l}\text { Gross } \\
\text { Alpha }\end{array}$ & $\begin{array}{c}\text { Gross } \\
\text { Beta }\end{array}$ \\
\hline $\begin{array}{l}\text { Water } \\
\text { Suppliers } \\
\mathrm{MCL}^{\mathrm{a}}\end{array}$ & 20,000 & 200 & \multicolumn{3}{|c|}{ NA } & \multicolumn{3}{|c|}{20 - Total Uranium } & 15 & 50 \\
\hline Maximum & 697 & ND & 0.084 & 0.112 & 0.013 & 15.7 & 1.23 & 14 & 26.90 & 58.00 \\
\hline Mean $^{b}$ & 90 & ND & 0.031 & 0.045 & 0.003 & 6.291 & 0.407 & 5.678 & 7.17 & 9.02 \\
\hline Minimum & -59.8 & ND & 0.007 & -0.013 & -0.006 & 0 & 0.011 & 0.018 & -1.00 & 2.36 \\
\hline $\begin{array}{l}\text { Number of } \\
\text { Analyses }^{c}\end{array}$ & $43(36)$ & $31(31)$ & $9(7)$ & $9(9)$ & $9(8)$ & $9(2)$ & $9(2)$ & $9(0)$ & $32(6)$ & $32(1)$ \\
\hline \multirow{2}{*}{\multicolumn{11}{|c|}{${ }^{\mathrm{a}}$ From 40 CFR 141 and EPA limit of $4 \mathrm{mrem} / \mathrm{yr}$ (see text). NA = not applicable }} \\
\hline & & & & & & & & & & ${ }^{\mathrm{b}}$ The mean has been calculated from all reported values. ND $=$ not detected \\
\hline
\end{tabular}

Laboratory analyses were performed for tritium in 43 water samples from 26 groundwatermonitoring wells (Figure 6-2). Of the 43 analyses performed, seven samples from four wells (all on-site wells) had tritium concentrations higher than the detection limits. The positive tritium identifications had maximum concentrations of $294,401,650$, and $697 \mathrm{pCi} / \mathrm{L}$ at wells $\mathrm{RD}-23$, $\mathrm{RD}-24, \mathrm{RD}-34 \mathrm{~B}$, and RD-54A, respectively. The maximum value among all the results, 697 $\mathrm{pCi} / \mathrm{L}$ in well $\mathrm{RD}-54 \mathrm{~A}$, is far below the EPA and California drinking water limit of 20,000 $\mathrm{pCi} / \mathrm{L}$. In 1999, two samples were taken from well RD-54A, and the results were $697 \pm 160$ $\mathrm{pCi} / \mathrm{L}(2 / 8 / 99)$ and $491 \pm 110 \mathrm{pCi} / \mathrm{L}(8 / 18 / 99)$. Well $\mathrm{RD}-54 \mathrm{~A}$ is located near the Former Sodium Disposal Facility 4886.

Historically, well RD-34A, located on recently acquired land near the RMHF in Area IV, had higher concentrations of tritium than other wells in Area IV. Figure 5-2 shows the historical tritium analysis results for RD-34A. For comparison, the allowable limit in drinking water, $20,000 \mathrm{pCi} / \mathrm{L}$, is used as the full scale on the plot. Since the first detection of about 7,000 pCi/L in 1992, the tritium concentrations in this well have dropped down to the range of 1,000 to 5,000 $\mathrm{pCi} / \mathrm{L}$. Because the well was dry in 1999 , no water samples could be taken from this well. RD$34 \mathrm{~B}$, adjacent to $\mathrm{RD}-34 \mathrm{~A}$ had tritium concentrations of $650 \pm 120 \mathrm{pCi} / \mathrm{L}(2 / 4 / 99)$ and $176 \pm 100$ $\mathrm{pCi} / \mathrm{L}(8 / 11 / 99)$.

$\mathrm{RD}-24$, near Building 4059, showed $220 \pm 120 \mathrm{pCi} / \mathrm{L}(2 / 2 / 99)$ and $401 \pm 110 \mathrm{pCi} / \mathrm{L}$ (8/11/99). No off-site wells showed the presence of tritium. The occurrence of tritium in groundwater appears to have resulted from unintended production of tritium in soil surrounding the reactor test vessel in Building 4010 . 


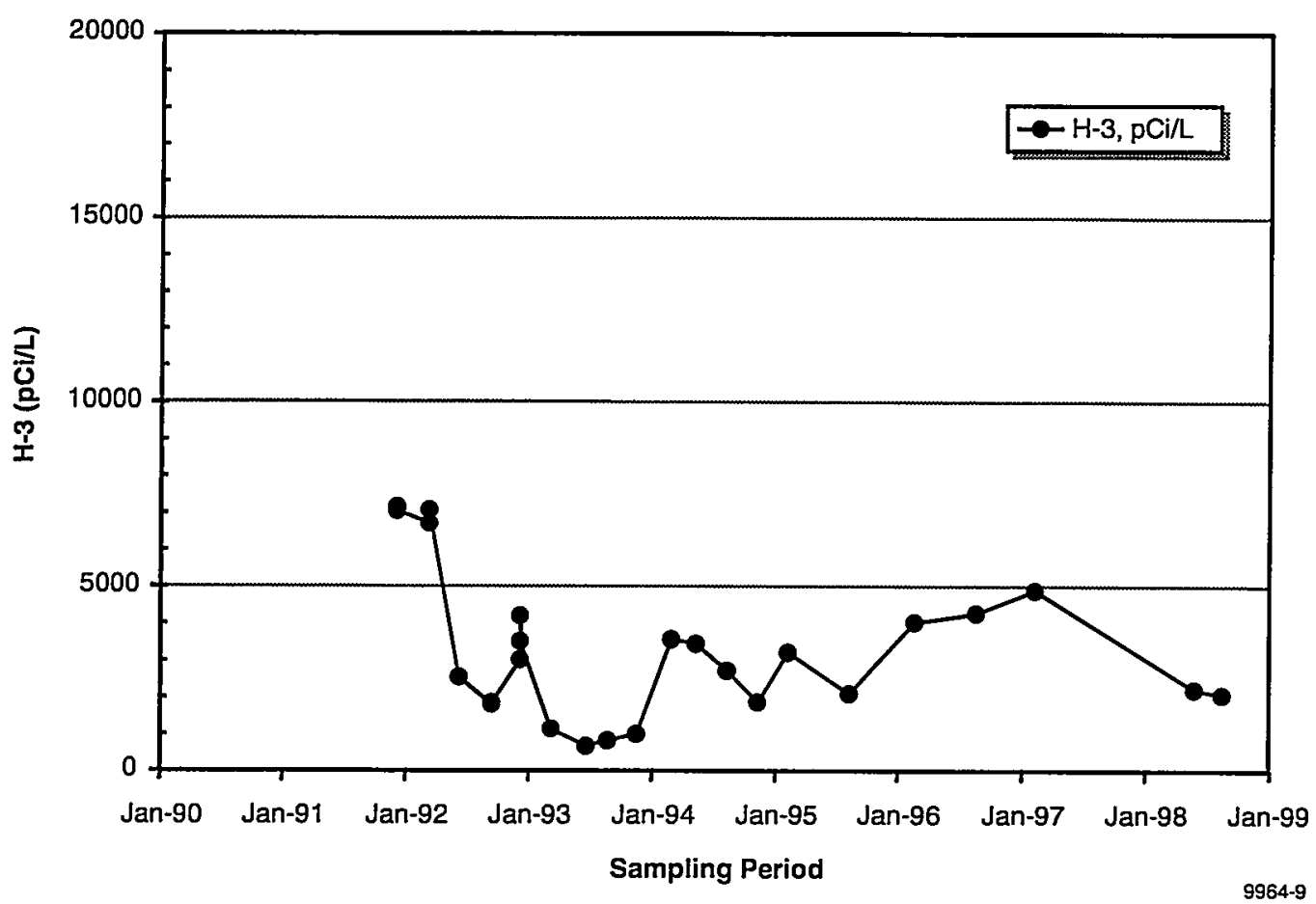

Figure 5-2. Tritium Concentration in Water from Well RD-34A

\subsubsection{Surface Water and Domestic Water Supply}

Most of Area IV slopes toward the southeast, and rainfall runoff is collected by a series of drainage channels and accumulates in the R2A Pond. Water from this pond is eventually released to Bell Creek under the NPDES permit. Some of Area IV slopes to the northwest, and a small amount of rainfall drains toward the northwest ravines, which lead into Meier Canyon. To permit sampling of this runoff, five catch basins were installed in 1989 near the site boundary to accumulate runoff.

Average radioactivity concentrations in these catch basin samples are summarized in Table 5-7. For radioactivity, the maximum contaminant limits (MCL) applicable to suppliers of drinking water (Title 22, Chapter 15, Article 5, Section 64443, of the California Code of Regulations) are imposed on releases from the two southern controlled discharge points (Outfalls 001 and 002) and the five northwest slope runoff channels (Outfalls 003 through 007).

There was no indication of any radiological contamination of surface water discharges, and all results were below the drinking water supplier limits established in the NPDES permit.

Domestic water in this area is supplied by a variety of municipal and regional organizations, including the Los Angeles Department of Water and Power, several Ventura County Waterworks Districts, the Metropolitan Water District, the Burbank Public Service Department, and the Oxnard Public Works Department. Most of the water is imported from distant sources, such as Owens Valley, the Feather River, and the Colorado River. Some water (for Burbank, Oxnard, and Moorpark) comes from local groundwater wells. The local water is blended with imported water and treated to ensure purity and safety. Water is transported in open aqueducts and enclosed pipelines and is stored in open reservoirs and underground settling 
basins. The State of California requires that these suppliers routinely monitor their water for many potentially hazardous materials (and less significant aesthetic quality factors, as well) and report the results of this monitoring to their customers on an annual basis. Tests for radioactivity are relatively limited, and are performed over an extended period of time, so not all parameters are reported in any one year. The results reported by local water suppliers during 1998 are shown in Table 5-8 and represent the averages of results of analysis of water supplied from the Burbank Public Service Department, the Metropolitan Water District (by far the largest supplier in the area), and the Ventura County Waterworks (District 1). Data for 1999 domestic water supplies were not available at the time of publication.

Comparison of the radioactivity concentrations in groundwater at SSFL from Table 5-7 with that of the local public supply water (Table 5-8) shows no significant differences in $\mathrm{H}-3$, Sr-90, gross alpha or gross beta activities.

Table 5-7. NPDES Discharge Radioactivity Data for Northwest Slope Monitoring-1999

\begin{tabular}{|l|c|c|c|c|}
\cline { 2 - 5 } \multicolumn{1}{c|}{} & \multicolumn{4}{c|}{ Activity (pCi/L) } \\
\cline { 2 - 5 } \multicolumn{1}{c|}{} & H-3 & Sr-90 & Gross Alpha & Gross Beta \\
\hline $\begin{array}{l}\text { Water Suppliers } \\
\text { MCL }\end{array}$ & 20,000 & 8 & 15 & 50 \\
\hline Maximum & 204 & 1.0 & 3.9 & 23 \\
\hline Mean $^{\text {a }}$ & 45.8 & 0.35 & 0.92 & 5.8 \\
\hline Minimum $^{n}$ & 0.0 & 0.0 & 0.0 & 0.7 \\
\hline $\begin{array}{l}\text { Number of } \\
\text { Analyses }\end{array}$ & $17(17)$ & $17(16)$ & $17(15)$ & $17(11)$ \\
\hline $\begin{array}{l}{ }^{b} \text { Average of all reported values. } \\
\text { bumbers in parentheses represent the number of analyses reported as less than the detectable limit. }\end{array}$ \\
\hline
\end{tabular}

Table 5-8 Domestic Water Supplies Radioactivity Data

\begin{tabular}{|l|c|c|c|c|c|c|}
\cline { 2 - 7 } \multicolumn{1}{c|}{} & \multicolumn{7}{c|}{ H-3 } & Sr-90 & $\begin{array}{r}\text { Ra-226+ } \\
\text { R-228 }\end{array}$ & Gross Alpha & Gross Beta & Uranium \\
\cline { 2 - 7 } & 20,000 & 8 & 5 & 15 & 50 & 20 \\
\hline $\begin{array}{l}\text { Water Suppliers } \\
\text { MCL }\end{array}$ & ND & 2.3 & 2.9 & 14.8 & 17.8 & 6.0 \\
\hline Maximum & ND & 1.1 & 1.3 & 5.6 & 6.9 & 3.6 \\
\hline Mean & ND & 0.2 & 0.0 & 1.0 & 1.2 & 0.0 \\
\hline Minimum & $19(19)$ & $20(13)$ & $23(7)$ & $24(5)$ & $22(3)$ & $22(4)$ \\
\hline $\begin{array}{l}\text { Number of } \\
\text { reports }\end{array}$ & $\begin{array}{l}\text { a } \\
\text { a Numbers in parentheses represent the number of report entries listed as not detected. } \\
\text { ND = Not Detected }\end{array}$ \\
\hline
\end{tabular}




\subsubsection{Soil}

The radioactivity in native rock and soil can serve as an indicator of any spread of contamination outside the operating facilities and other known areas of radioactive contamination. Soil radioactivity is due to various naturally occurring radionuclides present in the environment and due to radioactive fallout of dispersed nuclear weapons materials. Naturally occurring radionuclides include $\mathrm{K}-40$ and the uranium and thorium series (including radon and progeny). The radionuclide composition of local area surface soil has been determined to be predominantly $\mathrm{K}-40$, natural thorium, natural uranium, and their decay progeny. Radioactivity in nuclear weapons test fallout consists primarily of the fission-produced Sr-90, Cs-137, and Pu-239.

In 1999, a radiation survey was completed at Building 4133 and surrounding area, confirming that the facility and area meet the release limits approved by the DOE and the State of California DHS. The survey included the building structure, fenced yard, and two acres of surrounding land. The soil results proved that all samples taken from the area were well below the DCGL $_{\mathrm{W}}$ for each radioisotope [Liddy, 1999c].

After the demolition of Building 4020 (Hot Laboratory) was completed in 1998, surveys were conducted to prove that soils under the building foundations and from the surrounding areas were not contaminated. After backfilling was completed, a comprehensive MARSSIM Final Status Survey of the facility was completed in September 1999. The survey indicated that the highest Cs-137 activity in soil was $0.24 \mathrm{pCi} / \mathrm{g}$ (gross), or less than $1 \%$ of the cleanup standard of $9.2 \mathrm{pCi} / \mathrm{g}$ (net). All radioisotope soil concentrations confirmed that the 4020 area is suitable for release without radiological restrictions [Liddy, 1999a].

In addition, 62 soil environmental samples were taken from L-85, $23^{\text {rd }}$ Street, and the T-100 Trench areas during 1999. These samples were analyzed using the HPGe MCA (highpurity germanium [detector] multichannel analyzer) system for gamma emitters. Table 5-9 summarizes the results of these analyses. Only a small amount of man-made radionuclides, Cs-137, Mn-54, and Eu-155 were detected in some samples, and the quantities were well below the site-wide release limits.

\subsubsection{Vegetation}

No vegetation samples were collected in 1999.

\subsubsection{Wildlife}

No animal samples were collected in 1999. 
Table 5-9. Environmental Soil Radioactivity Data-1999

\begin{tabular}{|c|c|c|c|c|c|c|c|c|}
\hline & & \multicolumn{7}{|c|}{ Activity (pCi/g) } \\
\hline & & $M n-54$ & Cs-137. & Eu-155 & $K-40$ & Ra-226 & Th-228 & U-235 \\
\hline \multirow[t]{4}{*}{$L-85$} & Maximum & $1.11 \mathrm{E}-02$ & 4.91E-02 & 4.07E-02 & $2.15 E+01$ & $1.67 \mathrm{E}+00$ & $3.58 \mathrm{E}+00$ & $1.43 E-01$ \\
\hline & Mean & $1.11 \mathrm{E}-02$ & 3.82E-02 & 4.07E-02 & $1.90 \mathrm{E}+01$ & $7.93 \mathrm{E}-01$ & $3.58 \mathrm{E}+00$ & $9.33 E-02$ \\
\hline & Minimum & 1.11E-02 & 2.21E-02 & 4.07E-02 & $1.61 E+01$ & $3.66 \mathrm{E}-01$ & $3.58 \mathrm{E}+00$ & 2.99E-02 \\
\hline & $\begin{array}{l}\text { Number of } \\
\text { Analyses }\end{array}$ & $10(9)$ & $10(7)$ & $10(9)$ & $10(0)$ & $10(1)$ & $10(9)$ & $10(4)$ \\
\hline \multirow[t]{4}{*}{$23^{\text {rd }} \mathrm{St}$. } & Maximum & & & 7.83E-02 & $2.95 E+01$ & $6.06 \mathrm{E}+00$ & & 5.32E-01 \\
\hline & Mean & ND & ND & 7.83E-02 & $1.74 \mathrm{E}+01$ & $2.66 \mathrm{E}+00$ & ND & $1.42 \mathrm{E}-01$ \\
\hline & Minimum & & & 7.83E-02 & $7.96 \mathrm{E}+00$ & 8.95E-01 & & 5.44E-02 \\
\hline & $\begin{array}{l}\text { Number of } \\
\text { Analyses }^{b}\end{array}$ & $26(26)$ & $26(26)$ & $26(25)$ & $26(0)$ & $26(4)$ & $26(26)$ & $26(6)$ \\
\hline \multirow{4}{*}{$\begin{array}{l}\text { T-100 } \\
\text { Trench }\end{array}$} & Maximum & & 4.38E-01 & & $2.97 \mathrm{E}+01$ & $2.69 \mathrm{E}+00$ & & $1.64 \mathrm{E}-01$ \\
\hline & Mean & ND & 1.81E-01 & ND & 2.37E+01 & $1.55 \mathrm{E}+00$ & ND & $9.15 \mathrm{E}-02$ \\
\hline & Minimum & & 2.62E-02 & & $1.71 \mathrm{E}+01$ & 5.95E-01 & & 3.61E-02 \\
\hline & $\begin{array}{l}\text { Number of } \\
\text { Analyses }\end{array}$ & $26(26)$ & $26(16)$ & $26(26)$ & $26(2)$ & $26(10)$ & $26(26)$ & $26(11)$ \\
\hline
\end{tabular}

\subsubsection{Ambient Radiation}

During the later years of the nuclear programs at Atomics International and Rocketdyne, from 1974 through 1989, the ambient radiation monitoring program used rather complicated bulb-type dosimeters $\left(\mathrm{CaF}_{2}: \mathrm{Mn}\right)$. This was justified by the amount of nuclear materials handled in the operations at SSFL and De Soto, and by the low levels of radiation in the environment. At the termination of all nuclear work in 1989, such a program was no longer needed, and efforts were directed toward simplifying the program. This was done initially by using the same dosimeters (LiF) that were well established in use for personnel monitoring in radiation work. While these dosimeters are well suited to measuring exposures in the range of interest for compliance with occupational radiation regulations (doses "above background"), they are somewhat insensitive for environmental measurements since the resolution in terms of dose uses increments of 10 mrem per quarter. Using these dosimeters demonstrated that environmental exposures did not reach regulatory limits, but provided limited information on the actual exposure rates present around the facilities and in the neighboring environment.

In addition to the LiF TLDs discussed above, Rocketdyne began deploying, in the last quarter of 1995, environmental TLDs that use an aluminum oxide ("sapphire") chip. These TLDs are capable of determining doses in increments of $0.1 \mathrm{mrem}$ (compared to $10 \mathrm{mrem}$ for the LiF-based badges previously used). In addition, the aluminum oxide badge reporting is much more detailed, providing both gross and corrected readings for the locations. Proper use of the control badges supplied with these dosimeters allows elimination of the natural and transportation exposure that occurs before, during, and after the deployment of the environmental dosimeters to measure the ambient radiation. This permits accurate determination of the net exposure received while the 
environmental TLDs are in the field, exposed to the ambient radiation. In various intercomparisons, aluminum-oxide-based dosimeters have been shown to be among the most accurate dosimeters available in measuring environmental exposure rates.

The State DHS/RHB provides packages containing calcium sulfate $\left(\mathrm{CaSO}_{4}\right)$ dosimeters for independent monitoring of radiation levels at SSFL and in the surrounding area. These dosimeters are placed at specific locations along with the Rocketdyne TLDs. The State dosimeters are returned to the Radiologic Health Branch for evaluation. Data for these TLDs, which were placed at various Rocketdyne dosimeter locations both on-site and off-site, are also shown for 1999 in Table 5-10.

Table 5-10 shows that radiation exposures measured by Rocketdyne and the State DHS are slightly different. This is mainly due to the fact that two different types of TLDs were used in the measurement. In addition, because the DHS TLD data is not available for the $4^{\text {th }}$ quarter of 1999, the exposure rates are estimated based on the first 3 quarter's TLD data. Radiation doses measured at locations SS-12, -13, and -14, are slightly higher than the rest of the locations on-site. This is reflective of normal operations at the RMHF, which involve handling and shipment of radioactive material.

The natural background radiation level as measured by the off-site TLDs ranges from 48 to $75 \mathrm{mrem} / \mathrm{yr}$. At SSFL, the local background ranges from 72 to $89 \mathrm{mrem} / \mathrm{yr}$, based on the data from dosimeters SS-3, $-4,-6,-7,-8,-9,-11$, and EMB-1 and EMB-2 as shown in Table 5-10. The variability observed in these values can be attributed to differences in elevation and geologic conditions at the various sites. The altitude range for the dosimeter locations is from approximately $260 \mathrm{~m}(850 \mathrm{ft}) \mathrm{ASL}$ at the off-site locations to a maximum of approximately $580 \mathrm{~m}(1,900 \mathrm{ft})$ ASL at SSFL. Many SSFL TLD locations are also affected by proximity to sandstone rock outcroppings, which results in elevated exposure levels.

The external exposure rate at the Rocketdyne northern property boundary, the closest property boundary to the RMHF, was indistinguishable from natural background. This property line is approximately $300 \mathrm{~m}$ from the RMHF and separated by a sandstone ridge, effectively shielding the boundary from any direct radiation from the RMHF. Dosimeters placed on the RMHF side of this sandstone ridge (SS-11, -12 , and -13), approximately $150 \mathrm{~m}$ from the RMHF, read an average of $54 \mathrm{mrem} / \mathrm{yr}$ above background. This is considerably below DOE's 100 $\mathrm{mrem} / \mathrm{yr}$ limit specified in DOE Order 5400.5 "Radiation Protection of the Public and the Environment." The TLD results demonstrate that the potential external exposure at the site boundary is below the DOE's dose limit. 
Table 5-10. 1999 SSFL Ambient Radiation Dosimetry Data

\begin{tabular}{|c|c|c|c|c|}
\hline & 1999 & \multirow{2}{*}{$\begin{array}{c}\text { Annual Exposure (mrem) } \\
\text { by Rocketdyne }\end{array}$} & \multicolumn{2}{|c|}{ Average Exposure Rate $(\mu R / h)$} \\
\hline \multicolumn{2}{|c|}{ TLD Locations } & & Rocketdyne & State DHS ${ }^{\mathrm{a}}$ \\
\hline \multirow[t]{12}{*}{ SSFL } & SS-3 & 72.2 & 8.2 & 9.8 \\
\hline & SS-4 & 85.9 & 9.8 & 11.1 \\
\hline & SS-6 & 82.1 & 9.4 & 11.1 \\
\hline & SS-7 & 73.7 & 8.4 & 10.5 \\
\hline & SS-8 & 88.9 & 10.1 & 11.4 \\
\hline & SS-9 & 81.3 & 9.3 & 11.6 \\
\hline & SS-11 & 88.0 & 10.0 & 10.8 \\
\hline & SS-12 & 118.2 & 13.5 & 14.5 \\
\hline & SS-13 & 117.1 & 13.4 & 14.0 \\
\hline & SS-14 & 107.8 & 12.3 & 10.7 \\
\hline & EMB-1 & 87.1 & 9.9 & 11.8 \\
\hline & EMB-2 & 83.6 & 9.5 & 11.6 \\
\hline \multicolumn{2}{|c|}{ Mean Values } & 90.5 & 10.3 & 11.6 \\
\hline \multirow[t]{9}{*}{ Off-Site } & OS-1 & 74.5 & 8.5 & 9.1 \\
\hline & OS-5 & 48.4 & 5.5 & -- \\
\hline & BKG-11 & 60.5 & 6.9 & -- \\
\hline & BKG-12 & 61.8 & 7.1 & -- \\
\hline & BKG-13 & 53.0 & 6.1 & -- \\
\hline & BKG-15 & 66.9 & 7.6 & -- \\
\hline & BKG-18 & 62.6 & 7.1 & -- \\
\hline & BKG-19 & 66.2 & 7.6 & -- \\
\hline & BKG-22 & 56.0 & 6.4 & - \\
\hline \multicolumn{2}{|c|}{ Mean Values } & 61.1 & 7.0 & 9.1 \\
\hline
\end{tabular}

\subsection{ESTIMATION OF RADIATION DOSE}

\subsubsection{Individual Dose}

The total effective dose equivalent (TEDE) to any member of the public from all pathways (combining internal and external dose) shall not exceed $100 \mathrm{mrem} / \mathrm{yr}$ (above background) for DOE facilities. Although the three TLD monitoring stations to the north of the RMHF (i.e., SS-12, -13, and -14) recorded an external dose level at 54 mrem above the local background, the actual dose at the property boundary is likely to be indistinguishable from the natural background. This is because the high rocky terrain between the actual property line and the TLD monitoring stations act as an effective shield and make the exposure from direct radiation at the property line indistinguishable from background. Exposure from direct radiation at the nearest residence would also be indistinguishable from background for the same reason. 
Estimates of the internal dose from airborne releases assume a constant unsheltered exposure throughout the year, adjusted for wind direction frequency, and therefore considerably overestimate the actual annual averaged doses near the site. Estimated internal radiation doses due to atmospheric emission of radioactive materials from SSFL nuclear facilities are calculated using the EPA program CAP88-PC, and are many orders of magnitude below the radiation standards and are far below doses from internal exposure resulting from natural radioactivity in air. For the air pathway only, for DOE operations, the standard is $10 \mathrm{mrem} / \mathrm{yr}$ for committed effective dose equivalent, as established by EPA.

Public exposure to radiation and radioactivity is shown in Table 5-11. The table presents the estimated exposures in comparison to the regulatory standards. Dose values in the table represent both internal and external exposures.

\section{Table 5-11. Public Exposure to Radiation and Radioactivity from DOE Operations at SSFL-1999}

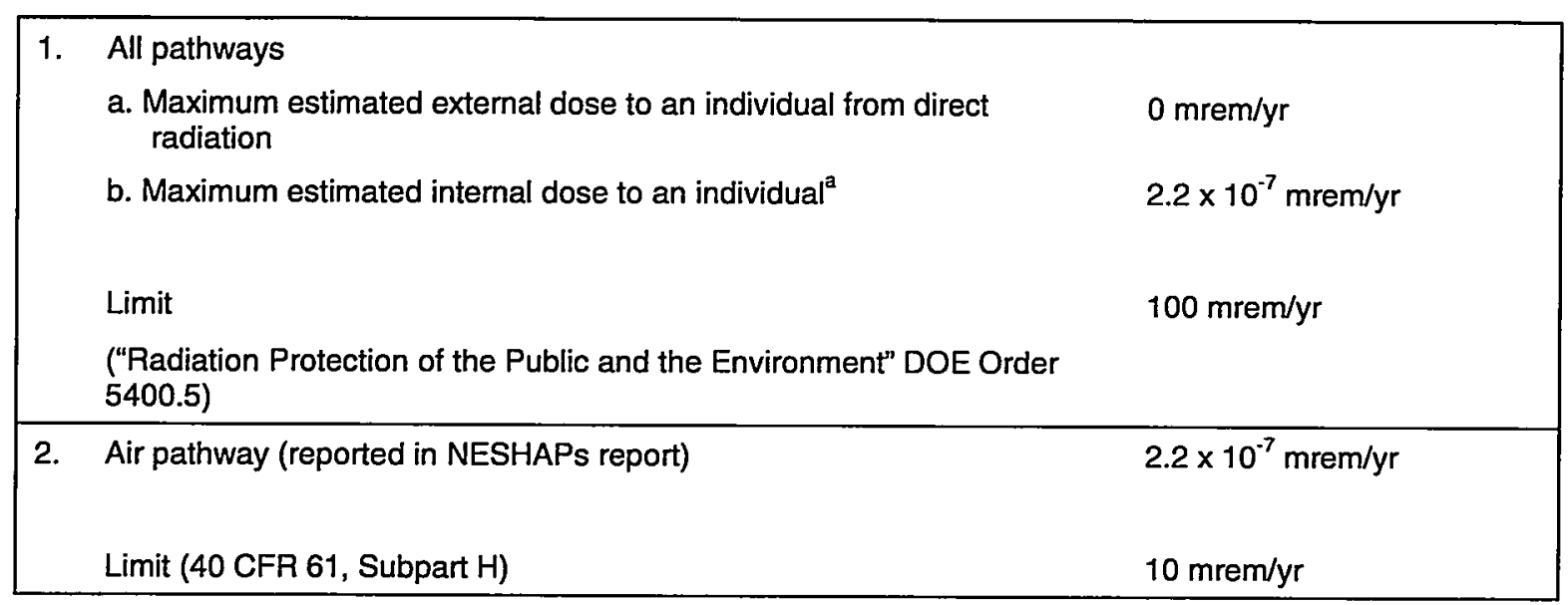

\subsubsection{Population Dose}

The general population (person-rem) dose estimates were calculated using the CAP88-PC code. This code uses release rate, wind speed, wind direction and frequency, stability fractions, and stack height parameters as input data. Population dose is estimated to be $4.8 \times 10^{-5}$ personrem for the SSFL site. This may be compared to the total population dose within $80 \mathrm{~km}$ radius from $300 \mathrm{mrem} / \mathrm{yr}$ of natural background radiation of $2 \times 10^{6}$ person-rem. In spite of the large number of people in the surrounding population, the population dose estimated for Rocketdyne operations is extremely small. Figure 5-3 shows the arrangement of the census tract boundaries from the 1990 census.

Figures 5-4 through 5-6 show local population distribution estimates that were determined from the 1990 Federal census by Urban Decision Systems, Inc., and modified by direct observation of nearby residential areas around the SSFL site, and the occupational population at SSFL. To account for population increases, analytical results using the 1990 census data were multiplied by 1.10 for Area IV of the SSFL. This factor was based on estimated population increases in Los Angeles and Ventura counties since 1990 as reported by the US Census Bureau. 


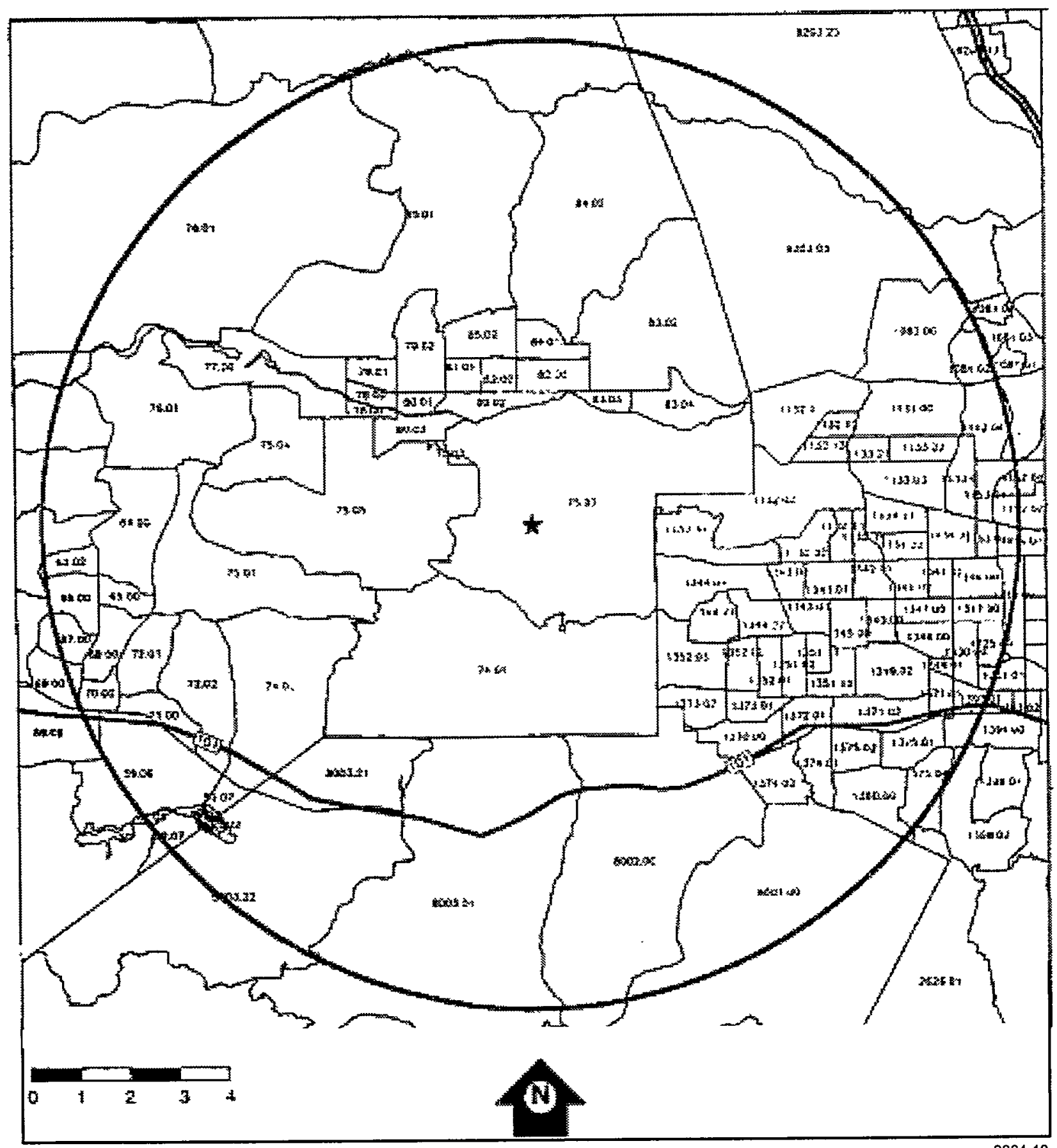

Figure 5-3. Census Tract Boundaries (1990) within 10 miles of SSFL (individual tracts are identified by number) 


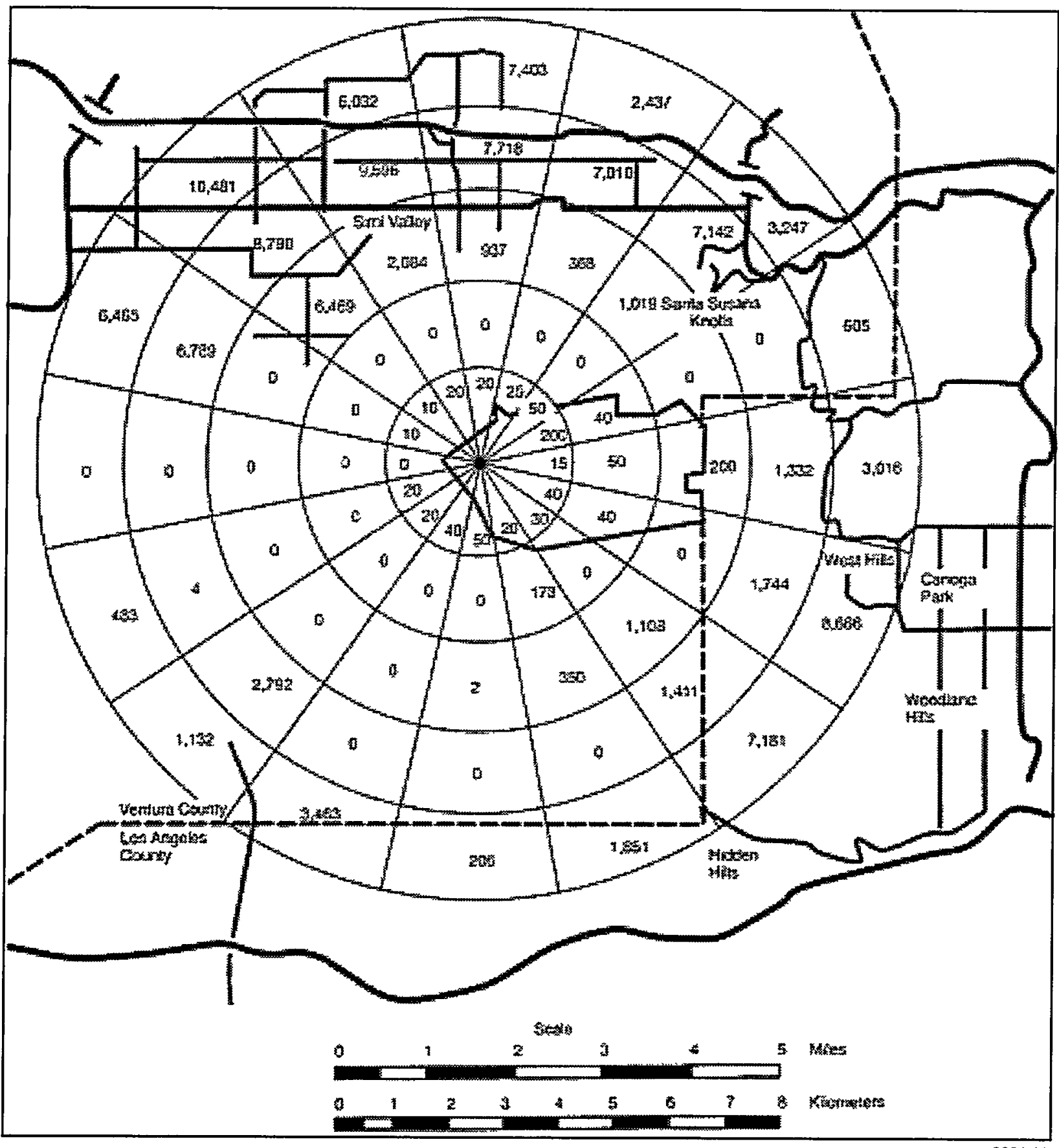

Figure 5-4. SSFL Site-Centered Demography to 8 km (1990), Showing Number of Persons Living in Each Grid (daytime employment for SSFL) 


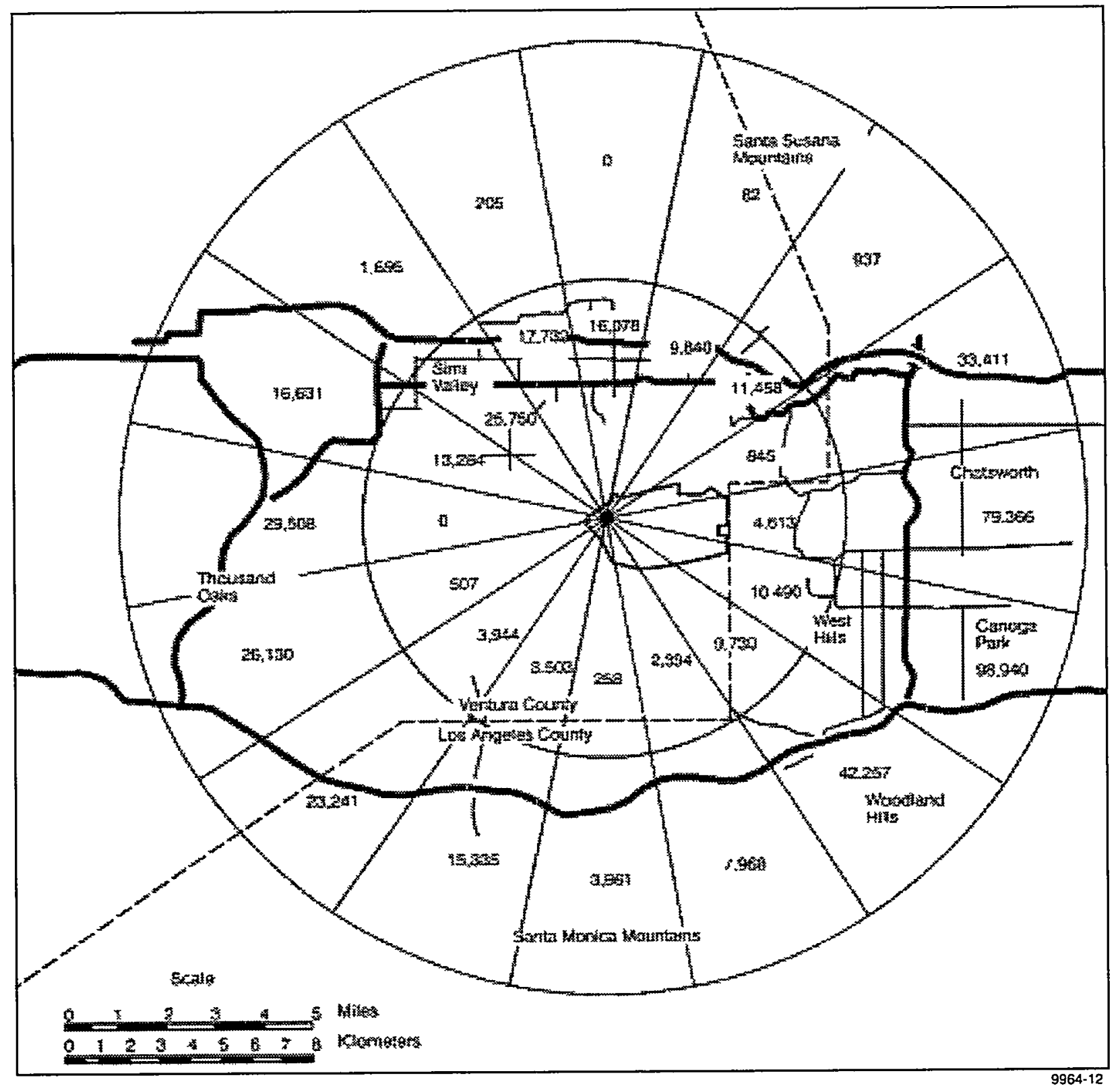

Figure 5-5. SSFL Site-Centered Demography to $16 \mathrm{~km}$ (1990), Showing Number of Persons Living in Each Grid 


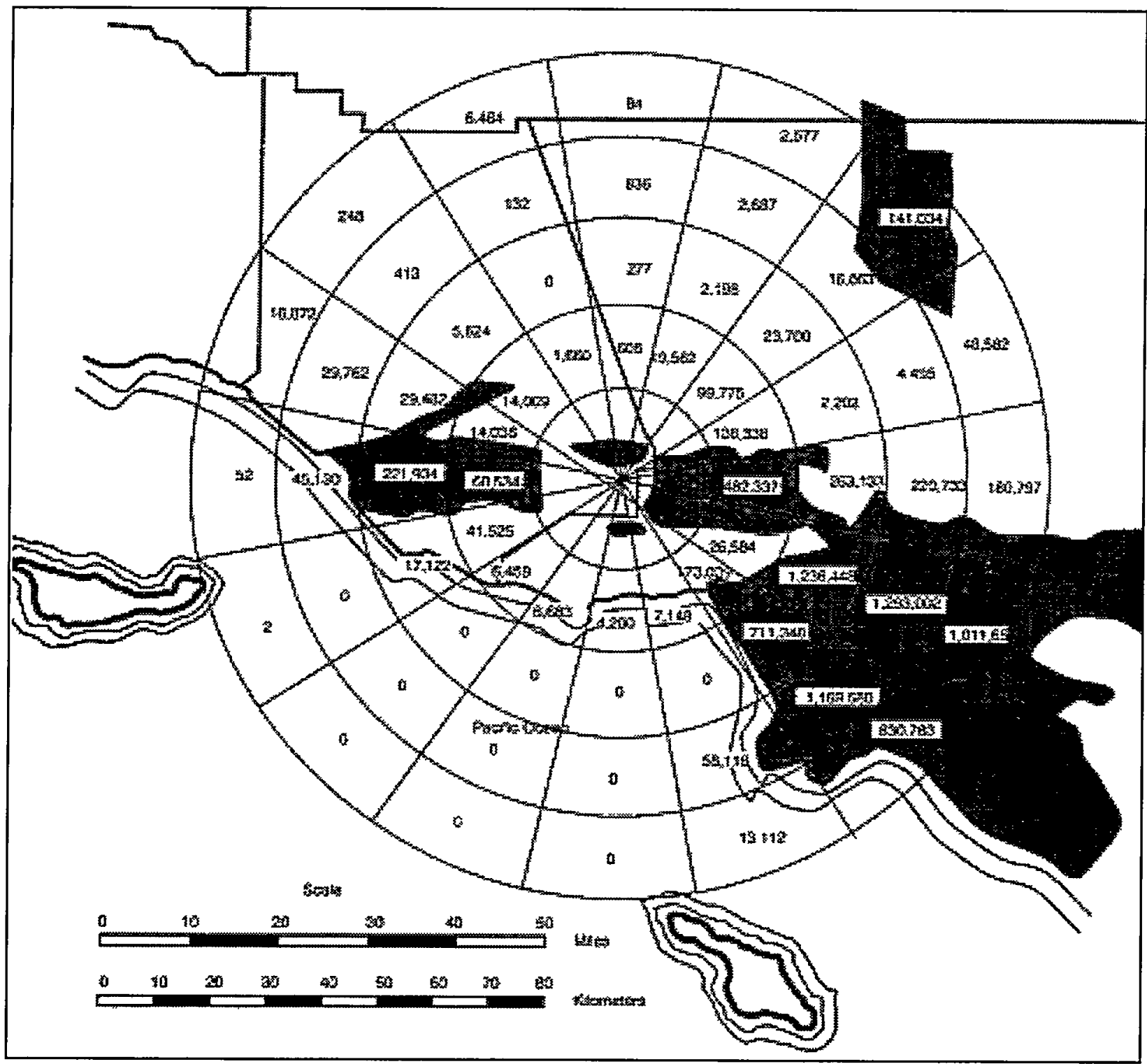

9964-13

Figure 5-6. SSFL Site-Centered Demography to $80 \mathrm{~km}$ (1990), Showing Number of Persons Living in Each Grid (heavily populated areas are shown by shading) 
RD00-159

This page intentionally left blank. 


\section{ENVIRONMENTAL NON-RADIOLOGICAL MONITORING}

Rocketdyne maintains a comprehensive environmental program to ensure compliance with all applicable regulations, to prevent adverse environmental impact, and to restore the quality of the environment from past operations.

The discharge of surface water at SSFL results from collection of rainfall runoff or is due to the nonutilization of treated groundwater and is regulated by the California Regional Water Quality Control Board through an NPDES permit. The majority of surface water runoff drains to the south and is collected in the water reclamation/pond system. Discharges from this system are subject to effluent limitations and monitoring requirements as specified in the existing NPDES permit. A small portion of the site within Area IV generates rainfall runoff to five northwest boundary runoff channels where monitoring locations (Figure 6-1) have been established and sampling is conducted in accordance with the northwest slope monitoring program. All discharges are periodically monitored for volatile organics, heavy metals, and applicable radionuclides, in addition to other parameters necessary to assess water quality.

All sources of air emissions at SSFL are subject to the provisions of the Clean Air Act as administered through the California Air Resources Board and the Ventura County Air Pollution Control District (VCAPCD). The VCAPCD regulates sources of air emissions and issues permits that contain limits on pollutant levels and conditions of operation.

An extensive site-wide (SSFL) groundwater remediation program has the capacity for removing solvent contamination from approximately 10 million gallons of groundwater per month at SSFL. The major groundwater contaminant in Area IV is TCE and its degradation products. Three interim groundwater extraction system wells have been installed in Area IV and evaluation of their performance is in progress. The overall annual groundwater monitoring program at SSFL addresses collection and analysis of groundwater samples and measurement of the water levels for the 247 Rocketdyne installed wells on-site and off-site and 16 off-site private wells. The locations of these wells within and around DOE areas in Area IV are shown on the map of SSFL in Figure 6-2. Groundwater quality parameters and sampling frequency have been determined based on historical water quality data, location of known or potential sources of groundwater contamination, operational requirements of groundwater extraction and treatment systems and regulatory direction. The groundwater monitoring program includes the following parameters, all analyzed using the appropriate EPA methods: volatile organic constituents, base/neutral and acid extractable organic compounds, petroleum hydrocarbons, and trace metals and common ion constituents. Radiological analyses are performed on groundwater samples from DOE areas in Area IV and off-site.

Petroleum hydrocarbon contaminated soils resulting from underground storage tanks (UST) have been remediated as tanks are removed. The majority of the storage tanks have been removed. The few remaining USTs contain either sodium or radioactive water and are located within concrete vaults and equipped with automatic leak detection systems. As stated previously, these tanks are exempt from the UST regulations. 


\subsection{SURFACE WATER}

Rocketdyne has filed a Report of Waste Discharge with the California Regional Water Quality Control Board and has been granted a discharge permit pursuant to the National Pollutant Discharge Elimination System and Section 402 of the federal Water Pollution Control Act. The permit to discharge, NPDES No. CA0001309, initially became effective September 27, 1976, and was most recently renewed on June 29, 1998. The current permit is in effect through May 10, 2003.

The permit allows the discharge of reclaimed wastewater and storm water runoff from water retention ponds into Bell Creek, a tributary to the Los Angeles River, in addition to the discharge of storm water runoff from the northwest slope (Area IV) locations. Discharge along the northwest slope (RMHF: Outfall 003, SRE: Outfall 004, FSDF West: Outfall 005, FSDF East: Outfall 006, and T100: Outfall 007) generally occurs only during and after periods of heavy rainfall. The permit applies the numerical limits for radioactivity in drinking water supplies to drainage through these outfalls. Excess reclaimed water is discharged on a continuous basis from the R-2A Pond that ultimately releases through Outfall 002.

There is no sanitary sewer connection to a publicly owned treatment works from SSFL. Domestic sewage is treated, disinfected, and discharged to the retention ponds. Permit conditions are placed on the operation of the two treatment plants. Area IV sewage is piped directly to the Area III Sewage Treatment Plant (STP III).

Of the two retention ponds at SSFL that discharge via the NPDES permit, only one receives influent from Area IV, and is referred to as $\mathrm{R}-2 \mathrm{~A}$ Pond. Influent to the ponds includes tertiary treated domestic sewage, cooling water from various testing operations, treated ground water and storm water runoff. During periods of discharge from the ponds, grab samples are collected and sent to a California State certified testing laboratory for analysis. Analyses include chemical constituents such as heavy metals, volatile organics, base/neutral and acid extractable, and general chemistry in addition to specified radionuclides. Toxicity testing is also conducted in the form of acute and chronic toxicity bioassays.

In November 1989, a storm water runoff program was developed and implemented in Area IV for runoff from the northwest portion of the site. Five monitoring locations were selected that include the Radioactive Materials Handling Facility watershed (Outfall 003), Sodium Reactor Experiment watershed (Outfall 004), the Former Sodium Disposal Facility (Outfalls 005 and 006), and behind T100 (Outfall 007). Runoff monitoring is currently conducted as set forth by the NPDES permit referenced above. Furthermore, all surface water program activities for the SSFL, including Area IV, have been addressed and incorporated into the current NPDES permit. The Storm Water Pollution Prevention Plan and the NPDES permit were both prepared in accordance with the current federal and state regulations.

The permit imposes the contaminant limits for drinking water suppliers, relative to radioactivity, and goes beyond the requirements of the drinking water supplier regulations in requiring more frequent sampling and analysis. During wet weather flow (rainfall is greater than 0.1 inch) no more than one sample per 2 weeks needs to be obtained from each of the seven outfalls. During dry weather flow, whenever there is discharge, minimum sampling frequency for Outfalls 001 and 002 is once per month. 
In 1999, Outfalls $004 ; 005$, and 006 all had incidents of noncompliance with analytical results reporting total mercury to be present at levels above the permitted monthly average of $0.012 \mu \mathrm{g} / \mathrm{L}$. Results from the dissolved mercury analyses were at nondetectable levels. Standard methods for total metals analysis requires the digestion of all matter collected in the sample, including sediment. Mercury has been detected in soil samples collected at the facility. Sediment control structures have been installed and will continue to be maintained and modified as necessary to control sediment migration. These areas are currently under investigation/ remediation through the oversight of the Department of Toxic Substances Control (DTSC). The Former Sodium Disposal Facility (FSDF) RCRA interim measures remediation project has been approved by the DTSC for the areas associated with Outfalls 005 and 006 and work began in late spring of 2000.

Outfall 005 also had analytical results for samples collected in 1999 indicating antimony to be present at a level slightly above the permit guidelines for daily maximum concentrations. The source of the antimony was discovered to be a plastic tarp in place at the FSDF, which is required as an interim control by both the DTSC and the RWQCB. The purpose of the tarp is to protect surface water quality by limiting the migration of soil from the excavation areas. Analytical information from the manufacturer of the tarp revealed that the tarp itself contains 846 parts per million (ppm) of antimony with a leachability of 3 to $5 \mathrm{ppm}$. The tarp was replaced with a non-antimony containing tarp and all additional sampling has been in compliance with the permitted limit.

Also at Outfall 005, analytical results for samples collected in November 1999 indicated dissolved copper to be present at levels slightly above the permitted monthly average of $11 \mathrm{ug} / \mathrm{L}$. All analytical results from samples collected at the outfall both before and after November 1999, indicate dissolved copper to be within permitted limits. It is believed that this was an anomaly as the analytical results were unable to be duplicated in follow-up sampling events.

Outfall 007 also had incidents of noncompliance in 1999. Sampling results from February and March 1999 showed antimony to be present at levels above the permitted daily maximum of $6 \mathrm{ug} / \mathrm{L}$. Analytical results from the March sampling also showed cadmium to be present at a level slightly above the permitted guidelines. An investigation revealed the likely source of antimony and cadmium to be an outside storage area for bricks of lead, antimony, and other metallic alloys that had been used in previous operations. Some pallets were covered with what appears to be the same antimony containing tarp that was discovered to be a source for antimony at Outfall 005 . The bricks were removed from the elements and analytical results collected since that time show both antimony and cadmium to be within the permitted guidelines.

Outfalls 002 and 003 had no incidents exceeding permit limits in 1999. All outfalls are on Rocketdyne property.

At the Area III Sewage Treatment Plant (STP III), the corrective actions implemented last year resulted in complete compliance with discharge standards in 1999. 


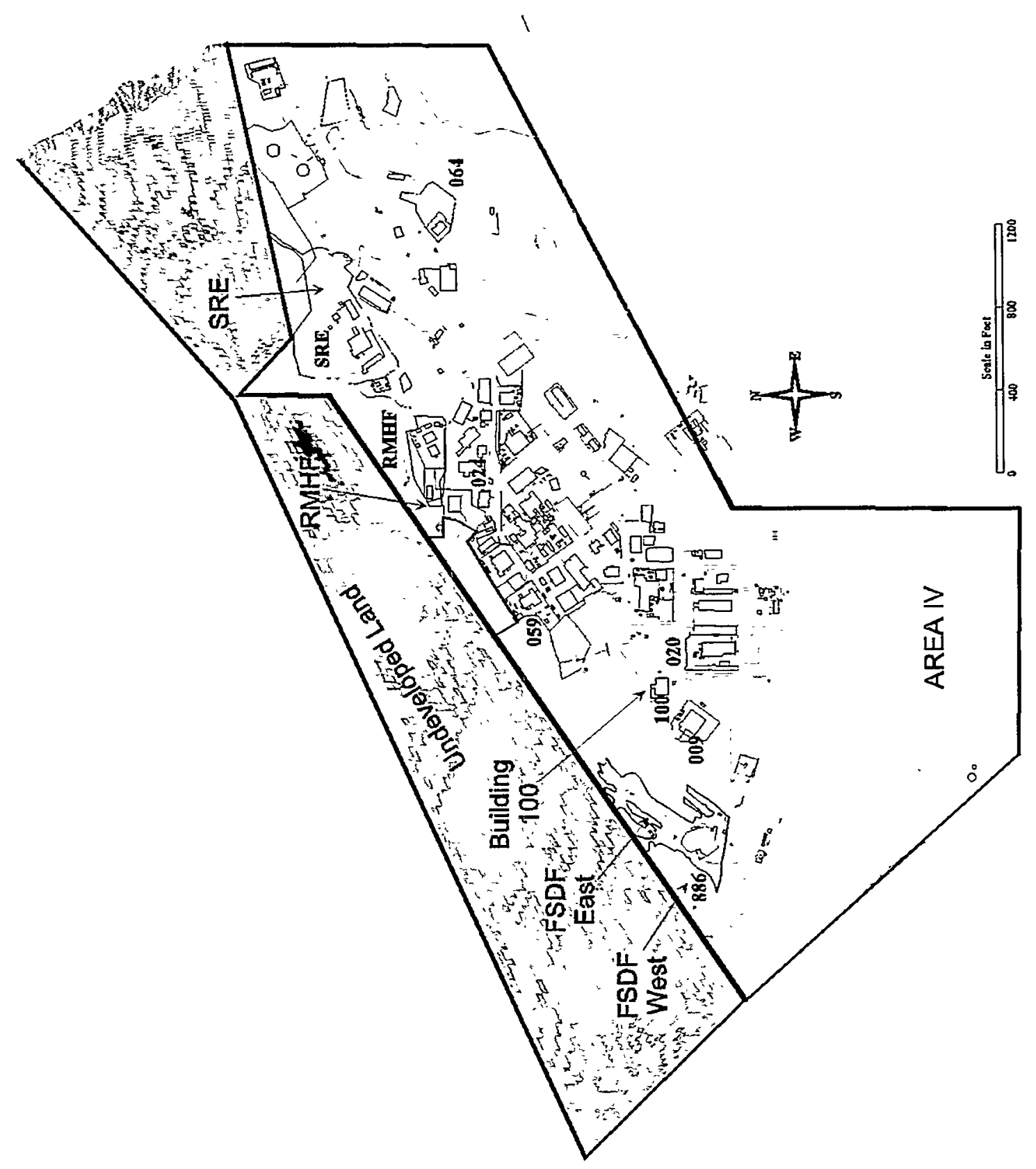

Figure 6-1. Locations of Surface Water Runoff Collectors Along Northwest Boundary of SSFL, Area IV 
$\frac{9}{1}$
$\frac{8}{8}$
8

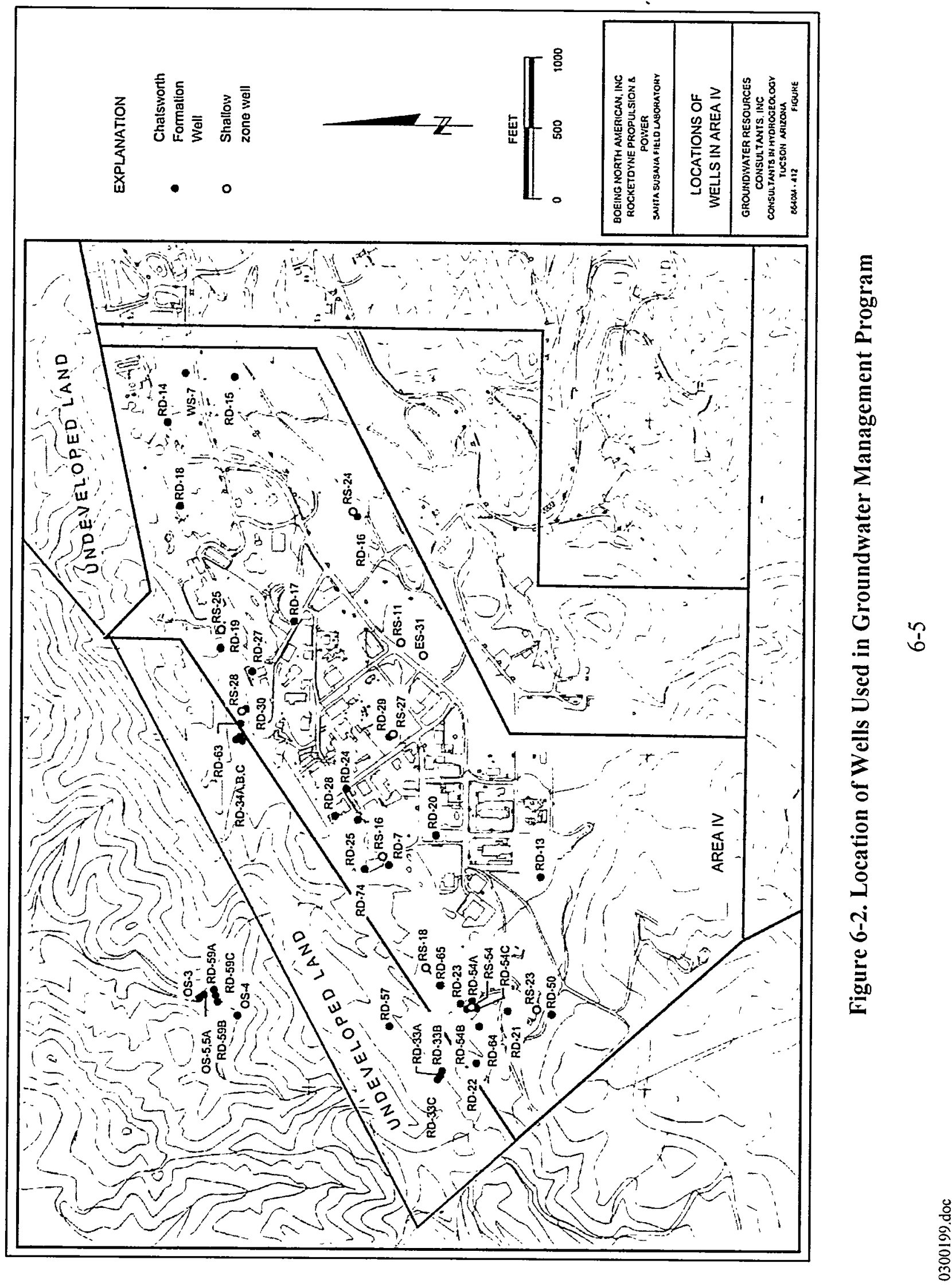




\subsection{AIR}

Atmospheric pollutant discharge limitations are imposed by VCAPCD Permit to Operate No. 0271. The air permit is kept current and is issued each year by the Ventura County Air Pollution Control District (VCAPCD).

At present, the sodium treatment facility (BIdg 4133) and the ethanol cleaning operation at SPTF (Bldg 4463) are the only permitted areas, however, Building 4133 has been in closure since June 1998.

Although ETEC has traditionally had little or no ODS's, Rocketdyne has for years maintained a Hazardous Materials Elimination Team to eliminate ODS's at Rocketdyne. This multifunctional team has the responsibility to identify suitable alternatives for various toxic chemicals and has been instrumental in eliminating CFC-113 and 1,1,1-trichloroethane from all of the Rocketdyne Southern California manufacturing operations. ETEC provided DOE with a complete inventory of Class I and Class II ODS's in October 1996.

\subsection{GROUNDWATER}

A groundwater monitoring program has been in place at the SSFL site since 1984. Currently, the monitoring system includes 247 on-site and off-site wells. Routine quarterly chemical and radiological monitoring of the wells is conducted according to the monitoring plan submitted to the lead agency for the groundwater program. Quarterly reports are submitted to the regulatory agencies at the end of the first three quarters. An annual report is submitted to the agencies after the monitoring for the fourth quarter is completed.

The groundwater at SSFL exists in two geologic units: Shallow Zone and the Chatsworth Formation. The Shallow Zone is an unconfined system in the alluvium (surface mantle soils) of the Burro Flats area and along the major drainage channels. The alluvium is composed of a heterogeneous mixture of gravel, sand, silt, and clay. Water levels in the alluvium respond to recharge resulting from precipitation and runoff, and may vary considerably between wet and dry periods. Within Area IV, there are nine DOE-installed Shallow Zone wells (excluded E5-31). The Chatsworth formation is composed of consolidated, massively bedded sandstones with interbedded layers of siltstone and claystone. The formation may be as thick as $6,000 \mathrm{ft}$ at the SSFL site. The regional direction of groundwater flow in the formation is probably radially offsite toward the surrounding lowlands. The permeability of the Chatsworth formation is very low except along open fractures. Groundwater within the fractured Chatsworth formation occurs mostly under confined conditions. There are 36 DOE-installed wells in and around Area IV.

The solvents found in the groundwater include trichloroethylene (TCE) and its family of degradation products. The analyses results of the Area IV wells have been documented in the "Area IV (Phase III) Groundwater Investigation Report" prepared for Rocketdyne by Groundwater Resources Consultants, Inc., in December 1992 [GRC, 1992], as well as in their 1999 Annual Report [GRC, 2000].

Three existing areas of TCE contamination in groundwater in the northwest part of Area IV were monitored in 1999. These areas are shown in Figure 6-3, where areas of suspected contamination equal to or above the State action level of $5 \mu \mathrm{g} / \mathrm{L}$ are shown as cross-hatched. The 
central occurrence may also extend laterally; however, no data are available because this area is . located in inaccessible terrain.

The TCE occurrence associated with the RMHF canyon (the northern occurrence) has been detected in the Shallow Zone and Chatsworth formation wells. The Shallow Zone well RS-28, which contained TCE concentrations up to $48 \mu \mathrm{g} / \mathrm{L}$ historically, could not be sampled during 1999 due to lack of water in the well. The Chatsworth formation well RD-30 contained $15 \mu \mathrm{g} / \mathrm{L}$ of TCE in 1999. RD-63, an extraction well installed in 1994 in the Chatsworth formation for the pilot extraction test in the area, detected 8.0 to $8.6 \mu \mathrm{g} / \mathrm{L} \mathrm{TCE}$ in 1999.

Within the central contaminated area (Figure 6-3) southwest of 4059, the Chatsworth formation well RD-7 contained TCE concentration from 48 to $56 \mu \mathrm{g} / \mathrm{L}$ in 1999 compared to 44 to $54 \mu \mathrm{g} / \mathrm{L}$ in 1998. Since its construction in 1986, RD-7 generally contained TCE concentrations in the 16 to $56 \mu \mathrm{g} / \mathrm{L}$ range with a maximum TCE concentration of $130 \mu \mathrm{g} / \mathrm{L}$. RD-25, located southwest of Building 4059, continued to contain perchloroethylene (PCE). In 1999, the well contained 10 to $19 \mu \mathrm{g} / \mathrm{L} \mathrm{PCE}$, compared to 24 to $35 \mu \mathrm{g} / \mathrm{L} \mathrm{PCE}$ in 1998.

Groundwater samples from two Shallow Zone wells (RS-18 and RS-54) of the southern contaminated area (Figure 6-3) near the FSDF at the western end of the site detected TCE concentrations from 1993 to 1997 . TCE in RS-54 ranged from 1,500 to $4,500 \mu \mathrm{g} / \mathrm{L}$ between 1993 and 1998. In 1999, TCE concentration ranged from 4,100 to $4,300 \mu \mathrm{g} / \mathrm{L}$. RS-18, often dry since its construction in 1985 , recorded TCE at $130 \mu \mathrm{g} / \mathrm{L}$ to $3,200 \mu \mathrm{g} / \mathrm{L}$ during the period from 1993 to 1998. RS-18 contained 1,000 to $1,170 \mu \mathrm{g} / \mathrm{L}$ TCE in 1999. RD-21 and RD-23, two Chatsworth formation wells installed in 1989 at the FSDF, contained TCE ranging from 88 to $2,400 \mu \mathrm{g} / \mathrm{L}$ during the period from 1993 to 1998. In 1999, TCE in these wells ranged from 280 to $620 \mu \mathrm{g} / \mathrm{L}$. RD-33A, a Chatsworth formation well (shallowest well of a three-well cluster constructed in 1991), contained 2.7 to $8.9 \mu \mathrm{g} / \mathrm{L} \mathrm{TCE}$ in 1999 , compared to 2.4 to $9.8 \mu \mathrm{g} / \mathrm{L}$ in the period from 1993 to 1998 . RD-65, a Chatsworth formation well located northeast of the FSDF contained $420 \mu \mathrm{g} / \mathrm{L} \mathrm{TCE}$ in 1999. TCE in the well was between 480 and $550 \mu \mathrm{g} / \mathrm{L}$ in 1998 .

The pilot extraction test at RMHF included installation of an extraction well and treatment of the extracted water in a portable carbon adsorption treatment unit. Results indicated that groundwater extraction in the test well at RMHF was effective in creating a capture zone for degraded groundwater. The capture zone extended up to $200 \mathrm{ft}$ down gradient of the extraction well. Two new wells were installed for the pilot test at the FSDF. Cyclic pumping of one to three wells was conducted in the test at this site, an area characterized by low yield of groundwater. Extraction and treatment of contaminated groundwater continued on an interim basis at RMHF and the FSDF in 1999. Groundwater from both sites is treated by liquid-phase carbon adsorption and is released southward to the surface water collection system. The activity at the FSDF was initiated in 1994 and at the RMHF in 1997. To date, approximately 107,000 gallons and 2.7 million gallons of groundwater have been treated from FSDF and RMHF areas, respectively. 


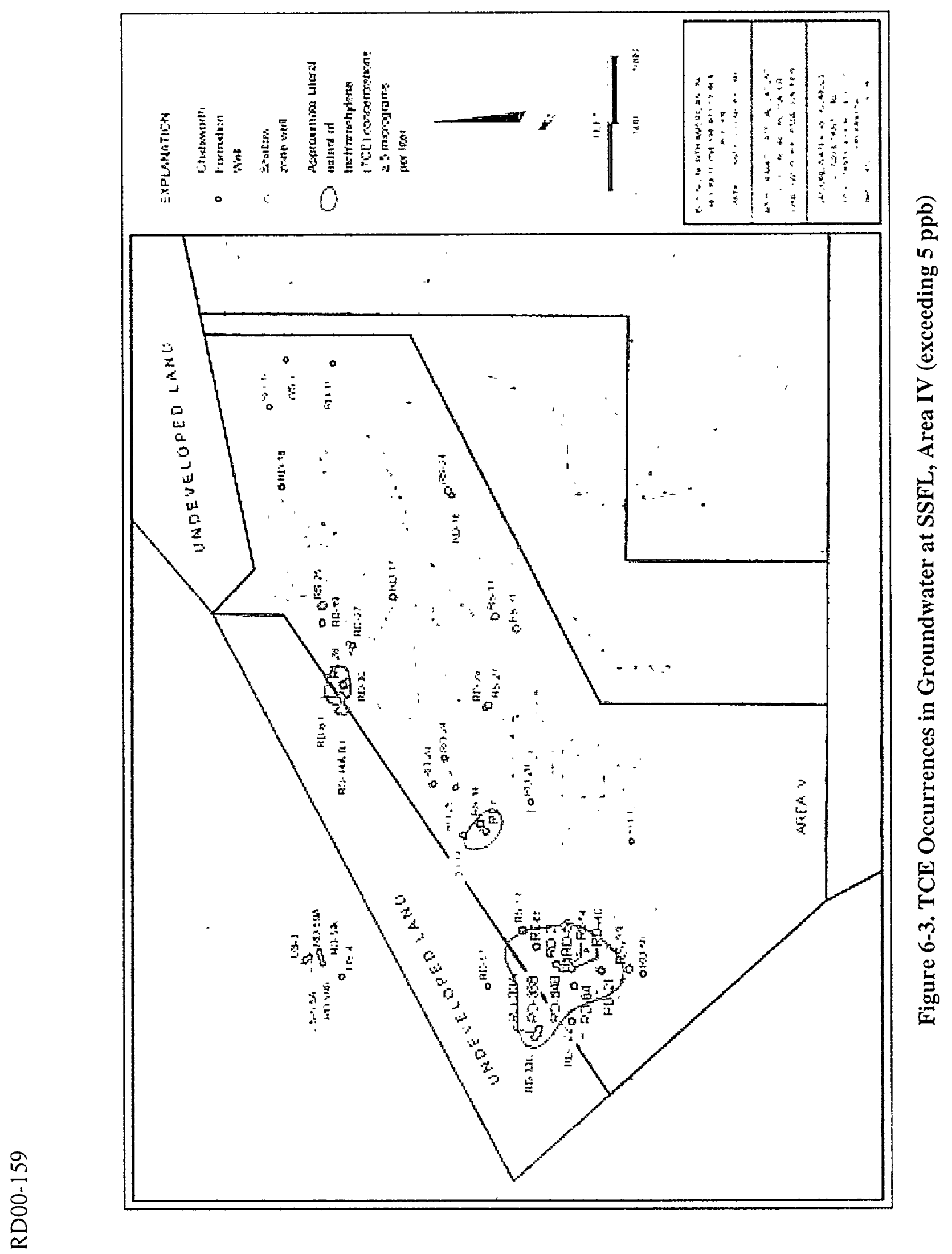

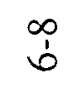




\section{ENVIRONMENTAL MONITORING PROGRAM QUALITY CONTROL}

This section describes the quality assurance (QA) elements incorporated into the Rocketdyne radiological analysis program that ensure data produced are as meaningful as possible.

The following elements of quality control are used for the Rocketdyne program:

1. Reagent Quality—Certified grade counting gas is used.

2. Laboratory Ventilation-Room air supply is controlled to minimize temperature variance and dust incursion.

3. Laboratory Contamination-Periodic laboratory contamination surveys for fixed and removable surface contamination are performed. Areas are cleaned routinely and decontaminated when necessary.

4. Control Charts-Background and reference source control charts for counting equipment are maintained to evaluate stability and response characteristics.

5. Laboratory Intercomparisons-Rocketdyne participates in the DOE EML-QAP.

6. Calibration Standards-Counting standard radioactivity values are traceable to NIST primary standards.

7. Co-location of State DHS thermoluminescent dosimeters.

\subsection{PROCEDURES}

Procedures followed include those for selection, collection, packaging, shipping, and handling of samples for off-site analysis; sample preparation and analysis; the use of radioactive reference standards; calibration methods and instrument QA; and data evaluation and reporting.

\subsection{RECORDS}

Records generally cover the following processes: field sample collection and laboratory identification coding; sample preparation method; radioactivity measurements (counting) of samples, instrument backgrounds, and analytical blanks; and data reduction and verification.

Quality control records for laboratory counting systems include the results of measurements of radioactive check sources, calibration sources, backgrounds, and blanks, as well as a complete record of all maintenance and service.

Records relating to overall laboratory performance include the results of analysis of interlaboratory cross-check samples and other quality control analyses; use of standard (radioactive) reference sources; and calibration of analytical balances. 


\subsection{QUALITY ASSURANCE}

Rocketdyne participates in the DOE Quality Assessment Program (QAP) operated by the Environmental Measurements Laboratory (EML) in New York for radiological analyses. During 1999, two sets of samples were distributed: QAP-50 and QAP-51 [DOE, 1999a; DOE, 1999b]. In 1994, EML analyzed the QAP historical data for air filter, soil, vegetation, and water samples from 1982 through 1992 to generate representative control limits for the performance evaluation of analytical services. The individual data values reported by the participating laboratories were normalized to the EML reference value, and the normalized values were grouped into percentiles. The middle $70 \%$ of all historical reported values (from the 15th to 85th percentile) was established as Acceptable and the next $10 \%$ on both sides of the 70\%-the 5th to 15th and 85th to 95th percentiles-as acceptable with Warning. Results outside this $90 \%$ band were considered not acceptable.

Rocketdyne and DOE use several laboratories for environmental sample analyses. Results of Rocketdyne, California DHS Sanitation and Radiation Laboratory, Oak Ridge Institute for Science and Education (ORISE), two of the vendor laboratories, and the average for all laboratories who participated in the QAP program are shown in Figure 7-1 for QAP-50 and QAP-51. Although these comparisons involve sample types, geometries, and analyses that are not part of the routine procedures at the Rocketdyne laboratory, historical review of the Rocketdyne results and those of the other laboratories has generally shown a similar level of quality.

The QAP soil and vegetation samples (200 and $100 \mathrm{~g}$, respectively) are significantly smaller than the typical 600-g sample size used at Rocketdyne for similar analyses. In 1996, Rocketdyne succeeded in modifying the small amounts of soil, vegetation, and water samples provided by the EML so that geometric effects had negligible impact on the analytical results. In 1997, Rocketdyne improved the air sample results over previous analyses. All quantitative environmental air samples for the site are analyzed by outside laboratories. For the present report, air and effluent filter samples were analyzed by Teledyne-Brown Engineering Environmental Services (Westwood, NJ), soil samples were analyzed by Quanterra St. Louis Laboratory, surface water samples were analyzed by Barringer Labs (Golden, CO) and FGL Environmental (Santa Paula, CA), and groundwater samples were analyzed by Thermo Nutech (Richland, WA). 


\section{Samples Acceptable - QAP 50 (9903)}
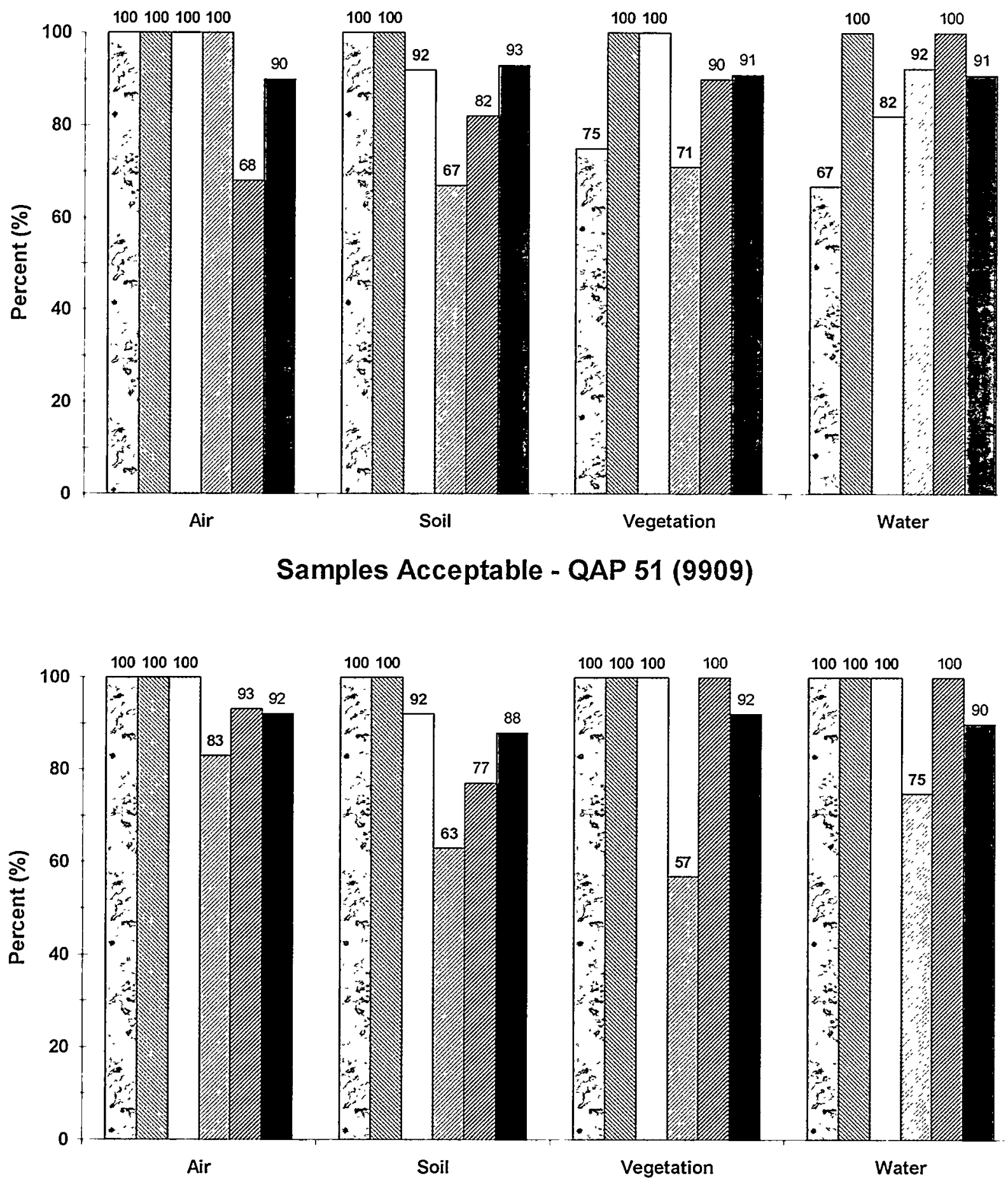

曰Rocketdyne $\mathrm{N}$ California DHS $\square$ ORISE 0 Teledyne-Brown $\approx$ Quanterra All Labs

Figure 7-1. Quality Assessment Program Results for QAP-50 and QAP-51 
RD00-159

This page intentionally left blank. 


\section{REFERENCES}

Atkinson, R., 1996. ETEC Waste Minimization and Pollution Prevention Awareness Plan. ETEC Document GEN-AN-0037, Rev. A. The Boeing Company, Rocketdyne, Canoga Park, CA.

ATSDR (Agency for Toxic Substances and Disease Registry), 1999. Draft Preliminary Site Evaluation-Santa Susana Field Laboratory. CERCLIS No. CAD074103771. Agency for Toxic Substances and Disease Registry. Atlanta, GA.

DHS (State of California Department of Health Services), 1999a. Letter from J. Rexroth to J. Barnes Dated July 30, 1999. State of California Department of Health Services, Sacramento, CA.

DHS (State of California Department of Health Services), 1999b. Letter from G. Wong to P. Rutherford Dated January 15, 1999. State of California Department of Health Services, Sacramento, CA.

DHS (State of California Department of Health Services), 1999c. Letter from D. Wesley to J. Barnes Dated January 20, 1999. State of California Department of Health Services, Sacramento, CA.

DOE (U.S. Department of Energy), 1990. General Environmental Protection Program Requirements. DOE Order 5400.1. U.S. Department of Energy. Washington, D.C.

DOE (U.S. Department of Energy), 1993. Radiation Protection of the Public and the Environment. DOE Order 5400.5. U.S. Department of Energy. Washington, D.C.

DOE (U.S. Department of Energy), 1999a. Semi-Annual Report of the Department of Energy, Office of Environmental Management, Quality Assessment Program. U.S. DOE Report EML-604. U.S. Department of Energy. Washington, D.C.

DOE (U.S. Department of Energy), 1999b. Semi-Annual Report of the Department of Energy, Office of Environmental Management, Quality Assessment Program. U.S. DOE Report EML-605. U.S. Department of Energy. Washington, D.C.

EPA (U.S. Environmental Protection Agency), 1992. Users Guide for CAP88-PC, Version 1. EPA/402-B-92-001. U.S. Environmental Protection Agency, Office of Radiation Programs. Las Vegas, NV.

FR (Federal Register), 1997. Certification of the Radiological Condition of Building T030 at the Energy Technology Engineering Center Near Chatsworth, CA. Docket No. ETEC-T030. In 62 FR 54446, Vol. 62, No. 202, October 20, 1997.

GRC (Groundwater Resources Consultants, Inc.), 1992. Area IV Groundwater Investigation Report. Groundwater Resources Consultants, Inc. Tucson, AZ. 
RD00-159

GRC (Groundwater Resources Consultants, Inc.), 2000. Annual Groundwater Monitoring Report, Santa Susana Field Laboratory, 1999. Groundwater Resources Consultants, Inc. Tucson, AZ. February 28, 2000.

Liddy, P. M., 1999a. Area 4020, MARSSIM Final Survey Report. Document RS-00010. The Boeing Company, Rocketdyne, Canoga Park, CA.

Liddy, P. M., 1999b. Building 4059, Final Status Survey Report (Phase I). Document RS-00008. The Boeing Company, Rocketdyne, Canoga Park, CA.

Liddy, P. M., 1999c. Building 4133 Radiation Survey Report. Document RS-00011. The Boeing Company, Rocketdyne, Canoga Park, CA.

NRC (U.S. Nuclear Regulatory Agency), 1997. Multi-Agency Radiation Survey and Site Investigation Manual (MARSSIM). NUREG-1575. U.S. Nuclear Regulatory Agency Washington, D.C.

Oldenkamp, R. D. and J. C. Mills, 1991. Nuclear Operations at Rockwell's Santa Susana Field Laboratory-A Factual Perspective. Rockwell Document N001ER000017, Rev. C. Canoga Park, CA.

Rocketdyne, 1999. Site Environmental Report for Calendar Year 1998. Document RD99-115. The Boeing Company, Rocketdyne, Canoga Park, CA.

Yu, C. et al., 1993. Manual for Implementing Residual Radioactive Material Guidelines Using RESRAD, Version 5.0. ANL/EAD/LD-2. Argonne National Laboratory. Argonne, IL. 


\section{APPENDIX A \\ ACRONYMS}

AFP

ALARA

Am

ANL

AOC

ASER

ASL

ATSDR

$\mathrm{Be}$

CAA

Cal/OSHA

CERCLA

CFR

Co

CRWQCB

Cs

CWA

CX

D\&D

DCG

DHS/EMB

DHS/RHB

DOD

DOE

DTSC

EA

EIS

EML

EP

EPA

ER

ETEC

ETS

Air Force Plant

As Low As Reasonably Achievable

americium

Argonne National Laboratory

Areas of Concern

Annual Site Environmental Report

Above Sea Level

Agency for Toxic Substances and Disease Registry

beryllium

Clean Air Act

California Occupational Safety and Health Administration

Comprehensive Environmental Response, Compensation, and Liability Act

Code of Federal Regulations

cobalt

California Regional Water Quality Control Board

cesium

Clean Water Act

Categorical Exclusion

Decontamination and Decommissioning

Derived Concentration Guide

DHS/Environmental Management Branch

Department of Health Services/Radiologic Health Branch

Department of Defense

Department of Energy

Cal-EPA Department of Toxic Substances Control

Environmental Assessment

Environmental Impact Statement

Environmental Measurements Laboratory

Environmental Protection

Environmental Protection Agency

Environmental Remediation

Energy Technology Engineering Center

Extraction and Treatment Center 
RD00-159

\begin{tabular}{|c|c|}
\hline $\mathrm{Eu}$ & europium \\
\hline $\mathrm{Fe}$ & iron \\
\hline FFCA & Federal Facilities Compliance Act \\
\hline FONSI & Finding of No Significant Impact \\
\hline FSDF & Former Sodium Disposal Facility \\
\hline GRC & Groundwater Resources Consultants, Inc. (Tucson, AZ) \\
\hline $\mathrm{H}$ & hydrogen \\
\hline $\mathrm{H}-3$ & tritium \\
\hline HEPA & High-Efficiency Particulate Air \\
\hline HPGe & High-Purity Germanium (Detector) \\
\hline HWMF & Hazardous Waste Management Facility \\
\hline K & potassium \\
\hline $\mathrm{lb}$ & pound(s) \\
\hline LDR & Land Disposal Restriction \\
\hline $\mathrm{LiF}$ & lithium fluoride \\
\hline LLNL & Lawrence Livermore National Laboratory \\
\hline LLW & Low Level Waste \\
\hline LMDL & Liquid Metal Development Laboratory \\
\hline $\mathrm{m}$ & meter(s) \\
\hline MARSSIM & Multi-Agency Radiation Survey and Site Investigation Manual \\
\hline $\mathrm{MCA}$ & Multichannel Analyzer \\
\hline MCL & Maximum Contamination Level \\
\hline MDA & Minimum Detectable Activity \\
\hline MEI & Maximally Exposed Individual \\
\hline $\mathrm{Mn}$ & manganese \\
\hline NASA & National Aeronautics and Space Administration \\
\hline $\mathrm{ND}$ & Not Detected \\
\hline NEPA & National Environmental Policy Act \\
\hline NESHAPs & National Emission Standards for Hazardous Air Pollutants \\
\hline NIST & National Institute of Standards and Technology \\
\hline NOD & Notice of Deficiency \\
\hline NOI & Notice of Intent \\
\hline NOV & Notice of Violation \\
\hline NPDES & National Pollutant Discharge Elimination System \\
\hline NRC & Nuclear Regulatory Commission \\
\hline NSPS & New Source Performance Standards \\
\hline
\end{tabular}


ODS

ORIA

ORAU

ORISE

$\mathrm{Pb}$

PCB

PCE

Po

ppm

$\mathrm{Pu}$

QA

QAP

$\mathrm{Ra}$

RA

R\&D

RCRA

RFA

RFI

RMHF

$\mathrm{Rn}$

ROD

RS

RWQCB

SABER

SARA

SCTI

SCTL

SHEA

SIPS

$S \& M$

SNAP

SPCC

SPTF

$\mathrm{Sr}$

SRAM

SRE
Ozone Depleting Substance

Office of Radiation and Indoor Air

Oak Ridge Associated Universities

Oak Ridge Institute for Science and Education

lead

Polychlorinated Biphenyl

Perchloroethene

polonium

parts per million

plutonium

Quality Assurance

Quality Assessment Program

radium

Radioactive

Research and Development

Resource Conservation and Recovery Act

RCRA Facility Assessment

RCRA Facility Investigation

Radioactive Materials Handling Facility

radon

Record of Decision

Radiation Safety

Regional Water Quality Control Board

Steam Accumulator Blow-Down Evaluation Rig

Superfund Amendments and Reauthorization Act

Sodium Component Test Installation

Small Component Test Loop

Safety, Health \& Environmental Affairs

State Implementation Plans

Surveillance and Maintenance

Systems for Nuclear Auxiliary Power

Spill Prevention Control and Countermeasure

Sodium Pump Test Facility

strontium

Standardized Risk Assessment Methodology

Sodium Reactor Experiment 
RD00-159

SSFL

SWPPP

STP

SWMU

Tc

TCE

TEDE

Th

TLD

$\mathrm{U}$

UST

VCAPCD

VCEHD

WVN
Santa Susana Field Laboratory

Storm Water Pollution Prevention Plan

Sewage Treatment Plant or Site Treatment Plan

Solid Waste Management Unit

technetium

Trichloroethylene

Total Effective Dose Equivalent

thorium

Thermoluminescent Dosimeter

uranium

Underground Storage Tank

Ventura County Air Pollution Control District

Ventura County Environmental Health Division

Water Vapor Nitrogen 


\section{DISTRIBUTION \\ (single enclosure unless otherwise noted)}

U.S. Department of Energy

Office of Scientific and

Technical Information

P.O. Box 62

Oak Ridge, TN 37831

M. Lopez (4 copies)

U.S. Department of Energy

Oakland Operations Office

1301 Clay Street, Suite 700-N

Oakland, CA 94612

U.S. Department of Energy

Environmental Measurements Lab

201 Varick Street, Fifth Floor

New York, NY 10014-4811

Steve Black

U.S. Department of Energy

Oakland Operations Office

1301 Clay Street, Suite 700-N

Oakland, CA 94612

Ross Natoli (5 copies)

U.S. Department of Energy, EH-412

Forrestal Bldg., Rm. 3G-089

1000 Independence Ave., S.W.

Washington D.C. 20585

County of Ventura

Fire Protection District

Hazardous Material Section

395 Willis Avenue

Camarillo, CA 93010

County of Ventura

Resource Management Agency

Ventura, CA 93009

Ventura County Board of Supervisors

800 South Victoria Blvd.

Ventura, CA 93009
Tom Kelly

U.S. Environmental Protection Agency

Region 9

75 Hawthorne Street

San Francisco, CA 94105

Gregg Dempsey

Center for Environmental Restoration,

Monitoring and Emergency Response

U.S. Environmental Protection Agency

944 E. Harmon Street

Post Office Box 98517

Las Vegas, NV 89193

Ed Bailey

California State Department of Health

Services

Radiologic Health Branch

714 "P" Street

Sacramento, CA 95201

Paul Baldenweg

California State Department of Health Services

Radiological Health Branch

1449 West Temple Street, Room 209

Los Angeles, CA 90026

California State Department of Health Services Environmental Health Investigation Branch 1515 Clay Street, $17^{\text {th }}$ floor

Oakland, CA 94612

Gerard Abrams

California Environmental Protection Agency

Department of Toxic Substances Control

Region 1

Facility Permitting Branch

10151 Croydon Way, Suite 3

Sacramento, CA 95827-2106 
Jim Ross

California Regional Water Quality Control Board

Los Angeles Region

101 Centre Plaza Drive

Monterey Park, CA 91754-2156

Los Angeles County Health Department

Occupational Health and Radiation

Management

Los Angeles, CA 90007

U.S. Nuclear Regulatory Commission

Office for Analysis and Evaluation of

Operational Data

Washington, DC 20555

Richard Turtil

Low Level Waste \& Decommissioning

Division of Waste Management

Office of Nuclear Material Safety \&

Safeguards

U.S. Nuclear Regulatory Commission

Washington, DC 20555-0001

Paul Fox

American Nuclear Insurers

Town Center, Suite 3005

29 Main Street

West Hartford, CT 06107-2445

City Manager of Simi Valley

2929 Tapo Canyon Road

Simi Valley, CA 93063

California State University, Northridge

Attn: Robert Marshall

Urban Archives Center

Oviatt Library - Basement, Room 4

18111 Nordhoff Street

Northridge, CA 91330

Simi Valley Public Library

Attention: Ms. Janet Weaver

2969 Tapo Canyon Road

Simi Valley, CA 93063
Platt Branch Library

Attn: Ms. Janet Metzler

23600 Victory Blvd.

Woodland Hills, CA 91367

The Honorable Cathie Wright

State Senate

$19^{\text {th }}$ District

2345 Erringer Road, Suite 212

Simi Valley, CA 93065

The Honorable Elton Gallegly

United States House of Representatives

$23^{\text {rd }}$ District

300 E. Esplanade Drive, No. 1800

Oxnard, CA 93030-1262

Dan Hirsch

Committee to Bridge the Gap

1637 Butler Street

Los Angeles. CA 90027

Sheldon Plotkin

3318 Culbert Avenue

Los Angeles, CA 90066

Barbara Johnson

6714 Clear Spring Road

Simi Valley, CA 93063

Jerome Raskin

18350 Los Alimos Street

Northridge, CA 91326

Mountains Recreation \& Conservation

Authority

Attn: Rorie Skei

5750 Ramirez Canyon Road

Malibu, CA 90265

Arthur Pinchev

Brandeis-Bardin Institute

1101 Pepper Tree Lane

Simi Valley, CA 93064 
The Honorable Barbara Boxer

United States Senate

Hart Senate Office Building, Suite 112

Washington, DC 20510

The Honorable Diane Feinstein

United States Senate

Hart Senate Office Building

Washington, DC 20510

The Honorable Bill Richardson

Secretary

Department of Energy

1000 Independence Avenue, SW

Washington, DC 20585

The Honorable Donna Shalala

Secretary

Department of Health and Human Services

200 Independence Avenue, SW

Washington, DC 20201

The Honorable Carol Browner

Administrator

Environmental Protection Agency

1200 Pennsylvania Avenue, NW

Washington, DC 20460

The Honorable Gray Davis

Governor

State of California

State Capitol

Sacramento, CA 95814
The Honorable Sheila James Kuehl

Assemblymember, $41^{\text {st }}$ District

State Capital

Sacramento, CA 95814

Felicia Marcus

Regional Administrator

U.S. Environmental Protection Agency

Region IX

75 Hawthorne Street

San Fransisco, CA 94105-3901

Julie Anderson

Director, Waste Management Division

U.S. Environmental Protection Agency

Region IX

75 Hawthorne Street

San Fransisco, CA 94105-3901

Burt Cooper

Chief, Energy Section

Federal Facilities Assessment Branch

Agency for Toxic Substances and Disease

Registry

Executive Park, Building 33

1600 Clifton Road NE, E-56

Atlanta, GA 30333

Richard Lesler

U.S. Environmental Protection Agency

Region 9

75 Hawthorne Street

San Francisco, CA 94105 
RD00-159

This page intentionally left blank.

D-4 


\section{Site Environmental Report Reader Survey--1999}

To Our Readers:

The Annual Site Environmental Report publishes the results of environmental monitoring in support of DOE-sponsored programs at Rocketdyne's Santa Susana Field Laboratory, and documents our compliance with federal, state, and local environmental regulations. In providing this information, our goal is to give our readership-regulators, scientists, and the public-a clear understanding of our environmental activities, the methods we use, how we can be sure our results are accurate, the status of our programs, and significant issues affecting our programs.

It is important that the information we provide is easily understood, of interest, and communicates Rocketdyne's efforts to protect human health and minimize our impact on the environment. We would like to know from you whether we are successful in achieving these goals. Your comments are appreciated and will help us to improve our communications.

1. Is the writing

$\square$ too concise? $\square$ too wordy? $\square$ uneven? $\square$ just right?

2. Is the technical content

$\square$ too concise? $\square$ too wordy? $\square$ uneven? $\square$ just right?

3. Is the text easy to understand?

$\square$ yes $\quad \square$ no

If you selected "no," is it:

$\square$ too technical $\square$ too detailed $\square$ other:

4. Is the report comprehensive?

Yes No

(please identify issues you believe are missing in the comments section)

5. Do the illustrations help you understand the text better?

Are the figures understandable?

Are there enough?

Too few?

Too many?

6. Are the data tables of interest?

Would you prefer short summaries of data trends instead?

7. Is the background information sufficient?

Are the methodologies described reasonably understandable?

8. Are the glossaries and appendices useful?

Other comments:

Please return this survey to Radiation Safety - M/S T038, The Boeing Company, Rocketdyne, 6633 Canoga Avenue, Canoga Park, CA 91309.

\section{OPTIONAL INFORMATION}

Name: Occupation:

Address: 